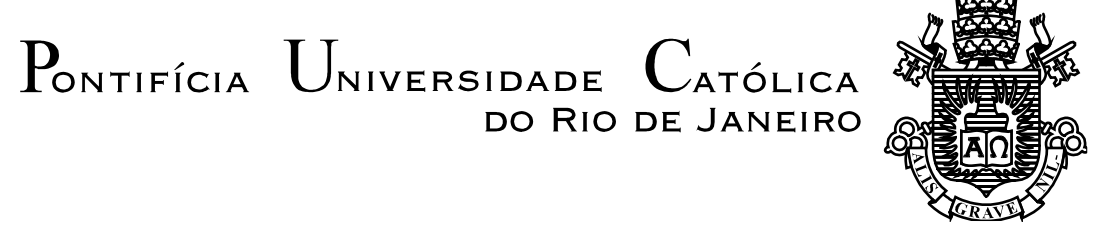

Amanda Costa Pinto de Morais

A atribuição de responsabilidade nas explicações
para a ocorrência de acidentes de trabalho

Dissertação de Mestrado

Dissertação apresentada ao Programa de Pós-graduação em Estudos da Linguagem da PUC-Rio como requisito parcial para obtenção do grau de Mestre em Letras/Estudos da Linguagem.

Orientadora: Profa. Maria do Carmo Leite de Oliveira 


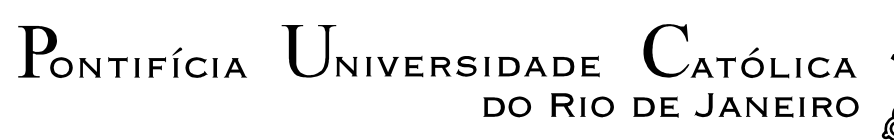

Amanda Costa Pinto de Morais

\section{A atribuição de responsabilidade nas explicações para a ocorrência de acidentes de trabalho}

Dissertação apresentada como requisito parcial para obtenção do grau de Mestre pelo Programa de Pósgraduação em Estudos da Linguagem da PUC-Rio. Aprovada pela Comissão Examinadora abaixo assinada.

Prof. Maria do Carmo Leite de Oliveira

Orientadora

Departamento de Letras - PUC-Rio

Profa. Maria das Graças Dias Pereira

Departamento de Letras - PUC-Rio

Prof. Gilson Brito Alves Lima

UFF

Profa. Monah Winograd Coordenadora Setorial do Centro de Teologia e Ciências Humanas - PUC-Rio

Rio de Janeiro, 01 de março de 2018. 
Todos os direitos reservados. É proibida a reprodução total ou parcial do trabalho sem autorização do autor, do orientador e da universidade.

\section{Amanda Costa Pinto de Morais}

Graduou-se em Letras (Português/Espanhol) na Universidade Federal Fluminense (UFF) em 2013. Durante a graduação, realizou intercambio na Universidad Nacional de San Martin (UNSAM) em Buenos Aires, no ano de 2011. Possui interesse em projetos relacionados aos estudos da linguagem em diversos contexto. Tem apresentado trabalhos voltados à análise do discurso, práticas cotidianas e profissionais.

Ficha Catalográfica

Morais, Amanda Costa Pinto de

A atribuição de responsabilidade nas explicações para a ocorrência de acidentes de trabalho / Amanda Costa Pinto de Morais ; orientadora: Maria do Carmo Leite de Oliveira. - 2018.

89 f. ; $30 \mathrm{~cm}$

Dissertação (mestrado)-Pontifícia Universidade Católica do Rio de Janeiro, Departamento de Letras, 2018.

Inclui bibliografia

1. Letras - Teses. 2. Responsabilidade. 3. Account. 4. Relatabilidade. 5. Segurança do trabalho. 6. Acidente. I. Oliveira, Maria do Carmo Leite de. II. Pontifícia Universidade Católica do Rio de Janeiro. Departamento de Letras. III. Título. 


\section{Agradecimentos}

Começo agradecendo a Deus, por tudo.

À minha mãe Marlene Costa, por ser um exemplo de mulher forte e guerreira. Obrigada pela educação e valores ensinados, pela compreensão e carinho, por me fazer acreditar que é possível. Você é a melhor mãe do mundo!

Ao meu marido Marcos Paulo, meu bem maior, que tanto admiro. Obrigada por todo carinho, amor, força, cumplicidade, compreensão e paciência. Pra frente e adiante!

Às minhas irmãs Aline e Cristiana, obrigada por alegrarem minha vida com meus sobrinhos.

À minha querida orientadora Maria do Carmo Leite de Oliveira, obrigada pelos ensinamentos, pelo carinho e paciência na conduta da orientação e por toda confiança depositada, desde o princípio, neste estudo. Obrigada por acreditar, te admiro!

Aos professores da banca, por aceitarem participar da defesa, pelas proveitosas críticas e sugestões.

Aos professores da Pós-Graduação em Estudos da Linguagem da PUC-Rio, especialmente a Liana de Andrade Biar e Liliana Cabral Bastos pelos ensinamentos e por todos incentivos na minha vida acadêmica.

Aos que aceitaram participar da pesquisa e todos que contribuíram de alguma forma para que este estudo pudesse ser realizado.

Ao meu amigo Diego Fernandes, obrigada por todo incentivo e apoio nessa trajetória acadêmica.

Aos meus companheiros de grupo de pesquisa: Amanda D., Carla, Carol e Rony, pelos debates acadêmicos, pelas dicas e incentivos. Obrigada pela acolhida.

Aos meus colegas de curso, especialmente à Clarissa, Jacque, Luis, Milena e Raquel. Obrigada pelas experiências compartilhadas.

A todos os funcionários da secretaria de Letras da Puc-Rio, especialmente à Chiquinha e a Di. E, aos funcionários da secretaria do Latec-UFF, especialmente à Bianca. Obrigada por serem tão solícitas.

À CAPES e à PUC-Rio, pelos auxílios concedidas. Foram providenciais. 


\section{Resumo}

Morais, Amanda Costa Pinto de; Oliveira, Maria do Carmo Leite. A atribuição de responsabilidade nas explicações para a ocorrência de acidentes de trabalho. Rio de Janeiro, 2018. 89p. Dissertação de Mestrado - Departamento de Letras, Pontifícia Universidade Católica do Rio de Janeiro.

O Brasil é o quarto país no ranking mundial de acidentes com vítimas fatais e o décimo quinto em relação aos demais acidentes de trabalho, segundo a Organização Internacional do Trabalho (OIT). Se as empresas são obrigadas a arcar com alíquotas maiores por lei pelos acidentes, o trabalhador, além de poder arcar com a vida, arca também com a culpa. É comum a liderança relacionar a ocorrência de um acidente a um comportamento inseguro do trabalhador. Essa visão é até certo ponto alimentada por uma literatura que enfatiza a responsabilidade do empregado justificando os acidentes através de categorias, como erro humano, ato inseguro, dentre outras. Este trabalho busca contribuir para os estudos das causas de acidentes de trabalho, examinando como a questão da responsabilidade é descrita por aqueles que gerenciam a segurança do trabalho. A partir de uma perspectiva etnometodológica, pretende-se identificar que concepções de senso comum sustentam as explicações que eles apresentam. O corpus é constituído de entrevistas realizadas com profissionais cuja posição hierárquica é mais próxima do "topo da pirâmide" e lidam com trabalhadores que executam atividades com risco iminente. Os resultados apontam, por um lado, a persistência da noção de ato inseguro, responsabilizando o trabalhador, com base em explicações que reforçam questões como agência, conhecimento e até intenção em provocar o acidente. Por outro lado, os resultados mostram também explicações que apontam para a responsabilização da empresa, o que nem sempre é assumido em casos de acidentes. Quanto àqueles envolvidos com o gerenciamento da segurança do trabalho, explicações de base cultural servem para desresponsabilizá-los, uma vez que a cultura da empresa e do trabalhador impossibilita qualquer ação eficaz. Dados esses resultados, verifica-se que, na prática, a tendência é buscar culpados e não apurar a responsabilidade de todos na ocorrência de acidentes.

\section{Palavras-chave}

Responsabilidade; account; relatabilidade; segurança do trabalho; acidente; risco; organizações. 


\section{Abstract}

Morais, Amanda Costa Pinto de; Oliveira, Maria do Carmo Leite (Advisor). The attribution of responsibility in explanations for the occurrence of occupational accidents. Rio de Janeiro, 2018. 89p. Dissertação de Mestrado - Departamento de Letras, Pontifícia Universidade Católica do Rio de Janeiro.

Brazil is the fourth country in the world ranking of accidents with fatal victims and the fifteenth in relation to other accidents at work, according to the International Labor Organization (ILO). If companies are forced to pay higher rates by law for accidents, the worker, in addition to being able to afford life, is also to blame. It is common for leadership to relate the occurrence of an accident to unsafe worker behavior. This view is to some extent fueled by a literature that emphasizes employee responsibility by justifying accidents through categories such as human error, unsafe act, among others. This research seeks to contribute to the study of the causes of occupational accidents, examining how the issue of responsibility is described by those who manage work safety. From an ethnomethodological perspective, we intend to identify which common-sense conceptions support the explanations they present. The corpus consists of interviews with professionals whose hierarchical position is closest to the "top of the pyramid" and deal with workers who carry out activities with imminent risk. The results indicate, on the one hand, the persistence of the concept of an unsafe act, making the worker responsible, based on explanations that reinforce issues such as agency, knowledge and even intention to cause the accident. On the other hand, the results also show explanations that point to the responsibility of the company, which is not always assumed in cases of accidents. As for those involved in the management of work safety, culturally based explanations serve to reassure them, since the culture of the company and the worker precludes any effective action. Given these results, it turns out that, in practice, the tendency is to seek guilty and not to ascertain the responsibility of all in the occurrence of accidents.

\section{Keywords}

Responsibility; account; relatability; workplace safety; accident; risk; organizations. 
Sumário

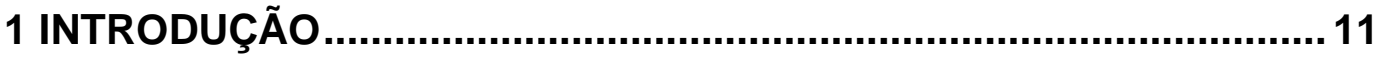

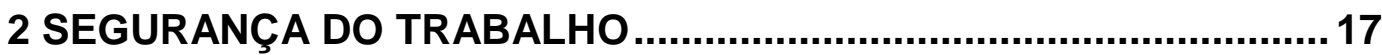

2.1 Breve histórico sobre a segurança do trabalho no Brasil.............17

2.2 A literatura sobre acidentes de trabalho ...................................... 19

2.3 A cultura de segurança no contexto organizacional ....................23

2.4 A legislação sobre responsabilidade civil......................................27

2.4.1 A tipologia da responsabilidade na legislação .......................... 27

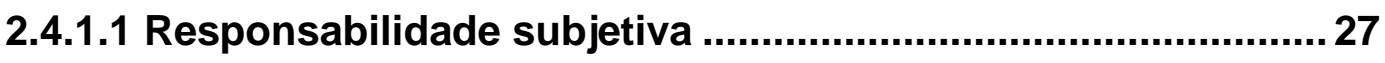

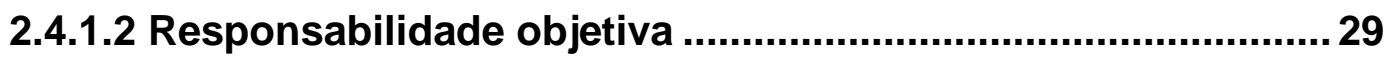

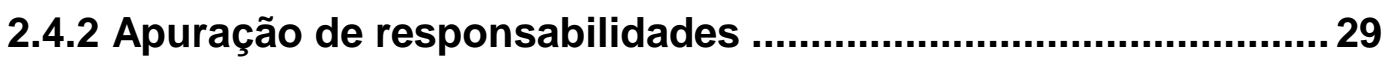

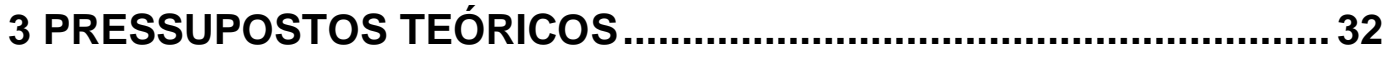

3.10 conceito de responsabilidade .................................................... 32

3.2 Os conceitos de relatabilidade e de account ...................................38

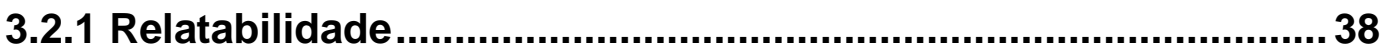

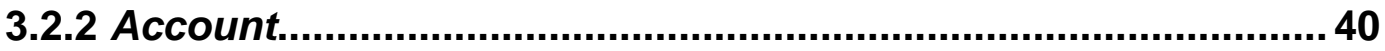

4 PRESSUPOSTOS METODOLÓGICOS.................................................4 44

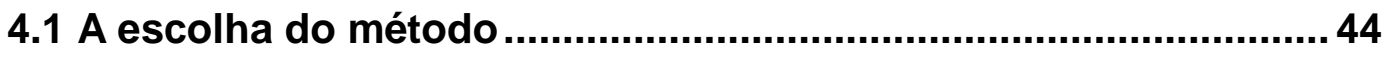

4.2 As escolhas do universo e da amostra da pesquisa ...................... 45

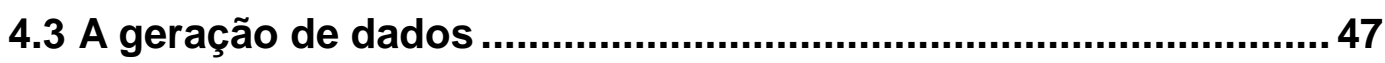

4.4 A escolha do procedimento analítico ............................................. 49

5 A VÍTIMA COMO RESPONSÁVEL ….............................................. 51

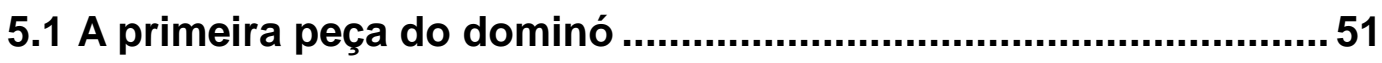

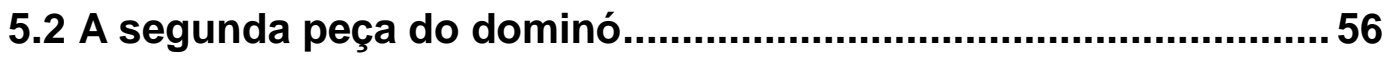


6 A EMPRESA COMO RESPONSÁVEL ............................................64

6.10 valor da segurança na cultura empresarial .................................64

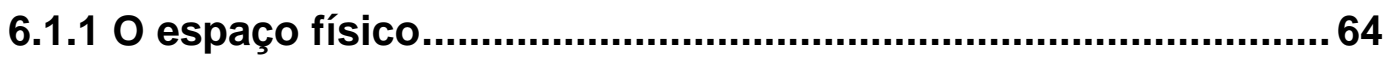

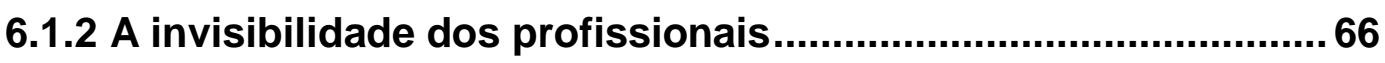

6.1.3 A inconsistência entre discurso e prática de segurança ............67

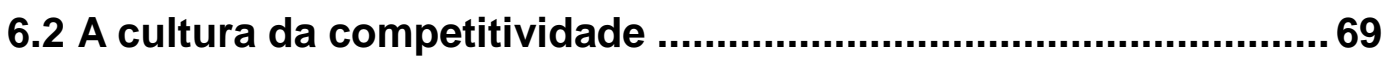

6.3 A política do acidente zero .............................................................

6.3.1 A não comunicação do acidente ................................................72

6.3.2 A prática da maquiagem de informações .....................................75

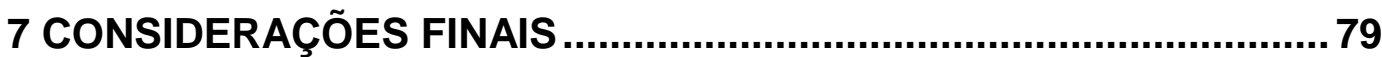

8 Referências bibliograficas

9 ANEXO 


\section{Lista de Quadros}

QUADRO 1 - Definições sobre cultura de segurança

QUADRO 2 - Evolução do conceito de cultura de segurança

26

QUADRO 3 - Fluxo do procedimento analítico 50 


\section{Lista de Siglas}

AEPS Anuário Estatístico da Previdência Social

CEPA Comissão Especial de Prevenção de Acidentes

CIPA Comissão Interna de Prevenção de Acidentes

CLT Consolidação da Leis do Trabalho

EPI Equipamento de Proteção Individual

FAT Fator Acidentário de Proteção

INPS Instituto Nacional de Previdência Social

INSS Instituto Nacional da Seguridade Social

NR Norma Regulamentadora

OIT Organização Internacional do Trabalho

PL Participação em Lucros

SESMT Serviço Especializado de Segurança e Medicina do Trabalho 


\section{1}

\section{Introdução}

Dentre as diversas funções administrativas desempenhadas por mim no mundo corporativo, a última foi a de secretária executiva da presidência de uma empresa de grande porte de seguimento de energia no Brasil. Ali, foi possível estar mais perto dos acontecimentos considerados mais "relevantes" para a empresa, quero dizer, aqueles que poderiam alavancar ou ameaçar a marca de alguma forma, e perceber como esses assuntos eram encaminhados.

No caso de acidentes de trabalho, havia uma rotina. Quando ocorria um acidente fatal, uma vez a cada dois ou três meses, recebíamos, no fim do dia, por email, um informativo de falecimento. Viver aquela experiência de perda me motivou a querer pesquisar o tema dos acidentes de trabalho em área de risco.

O Brasil apresenta índices alarmantes a respeito da predominância de acidentes de trabalho (COSTA et al.; 2013), ocupando uma posição preocupante comparada à de outros países. Ele é o quarto país no ranking mundial de acidentes com vítimas fatais e o décimo quinto em relação aos demais acidentes de trabalho, segundo a Organização Internacional do Trabalho (OIT) ${ }^{1}$. De acordo com o Anuário Estatístico da Previdência Social (AEPS) ${ }^{2}$, os dados de 2015, mais recentes e disponíveis na plataforma, revelam lentidão na diminuição de acidentes, sobretudo os típicos, isto é, aqueles decorrentes da característica da atividade profissional desempenhada pelo acidentado. No ano de 2013, foram registrados 434.339 acidentes típicos; no ano de 2014, foram 430.454 e, no ano de 2015, foram registrados 383.663. Apesar de os números já demonstrarem índices inquietantes, eles podem ser ainda maiores, pois a estatística leva apenas em consideração os trabalhadores com vínculos formais.

Os acidentes de trabalho têm elevado ônus para toda a sociedade, pois, além da questão social, com mortes precoces e mutilações, há também perdas

\footnotetext{
${ }^{1}$ A OIT foi criada em 1919 como parte do Tratado de Versalhes. Ela é responsável pela formulação e aplicação das normas internacionais do trabalho (convenções e recomendações). Disponível em: http://www.ilo.org/brasilia/lang--pt/index.htm
}

2 Disponível em: http://www.previdencia.gov.br/wp-content/uploads/2015/08/AEPS-2015FINAL.pdf 
financeiras com a concessão de benefício acidentário e a redução da produtividade no mercado. Torna-se indispensável, portanto, reduzir o custo econômico e social mediante medidas de prevenção. Apesar dos investimentos das empresas em campanhas de prevenção, a luta no combate aos acidentes de trabalho é diária, especialmente em áreas cujas tarefas são mais sensíveis ao risco.

O interesse pelo tema dos acidentes de trabalho em atividades de alto risco deixou de ser apenas uma motivação quando, durante o mestrado, iniciei uma revisão da literatura sobre o assunto. Ali o tema se transformou também em um objeto intelectual. O levantamento bibliográfico revelou que, apesar de haver diversos tipos de teorias sobre acidentes de trabalho, era comum o tratamento da responsabilidade pelo acidente na esfera individual, desconsiderando-se o contexto amplo, isto é, o processo, as pessoas envolvidas, os equipamentos, os fatores externos, dentre outros.

A referência clássica dessa visão é o estudo de Heinrich, a Teorias dos Dominós, que busca explicar os acidentes de trabalho como decorrentes de atos inseguros, não cumprimento das normas de segurança por parte dos trabalhadores, mau comportamento dos empregados, erro ou falha humana (ALMEIDA \& JACKSON FILHO, 2007). Por esta abordagem, substitui-se, assim, a causa pela culpa e, consequentemente, não há um aprofundamento da análise das circunstâncias e do processo de produção (CÂMARA et al., 2007). Nessa linha, a interpretação do que provocou um acidente fica restrita à ação de um único indivíduo num dado momento e lugar. Subjaz a esse modelo uma crença de que a responsabilidade de todos os envolvidos estaria limitada a comunicação das normas de segurança. Se a empresa ofereceu as condições seguras, se a liderança "treinou" os trabalhadores, os trabalhadores são os únicos responsáveis pelos acidentes. Neste trabalho, assumimos um modelo mais operacional de comunicação, aquele em que todos os participantes são corresponsáveis pelo resultado de uma interação. Ao nos propormos analisar as crenças de senso comum que alimentam as explicações das lideranças para os acidentes, revelamos essa "caixa preta" de outras interações que envolvem um acidente.

A influência da Teoria dos Dominós e de outras que reduzem o problema ao fator comportamental pode ser evidenciada na declaração do presidente do Tribunal Superior do Trabalho, Yves Gandra Martins Filho, em audiência pública 
no Senado, em maio de 2017, ao discutir a Reforma Trabalhista:

(...) pode acontecer o que acontecia em época de guerra, às vezes o soldado que não queria enfrentar a batalha arranjava um ferimento, em geral era sempre na mão esquerda e algum dedo para poder não ter que ir para batalha, às vezes, uma coisa dessas, se você começar a admitir indenizações muito elevadas o trabalhador pode acabar até provocando um acidente ou deixando que aconteça porque para ele vai ser melhor. ${ }^{3}$

Não buscamos aqui trazer à luz a discussão sobre o valor adequado para as indenizações, mas, sim, o argumento utilizado pelo presidente do Tribunal Superior do Trabalho para a ocorrência de acidentes. Ora, será que realmente um trabalhador, que necessita, na maioria das vezes, sustentar a família, iria se submeter a perder parte do corpo em troca de uma quantia finita de dinheiro? $\mathrm{O}$ acidente pode ser de fato intencional?

Sabe-se que o impacto dos acidentes nas empresas é refletido nas taxas que são obrigadas a arcar, pois quanto mais acidentes, maior é a alíquota de tarifação do Fator Acidentário de Proteção (FAT), que custeia acidentes e doenças do trabalho, além do impacto na Previdência com aposentadorias especiais.

Mas sabe-se também que há outras teorias que tentam criar modelos que incluem outros fatores que favorecem a ocorrência de acidente, como o Método de Árvore de Causas, que inclui as relações sociais como componente para a causa de acidentes, e a Teoria Social do Erro, que afirma que os acidentes de trabalho são produzidos de acordo com os níveis de relações sociais, ou seja, a maneira como trabalhador e o gerenciamento de seu trabalho se relacionam.

Observamos que se algumas teorias apontam responsáveis pelos acidentes (como a do Dominó), outras apresentam modelos de causas de acidentes que não apontam para agentes responsáveis, o que nos leva a algumas perguntas de pesquisa:

i) Quais as "teorias internas" que as lideranças envolvidas em gestão da segurança do trabalho têm para explicar os acidentes?

ii) Que crenças de senso comum sustentam essas teorias?

iii) Como a questão da responsabilidade emerge nas explicações

\footnotetext{
${ }^{3}$ Matéria completa disponível em: https://www.brasil247.com/pt/247/brasil/295973/Presidentedo-TST-diz-que-trabalhador-se-fere-de-prop\%C3\%B3sito-por-indeniza\%C3\%A7\%C3\%A3o.htm Acesso em 04 de fevereiro de 2017
} 
oferecidas pelas lideranças para a ocorrência de acidentes?

iv) Quem é responsabilizado e desresponsabilizado?

Em busca de respostas aos nossos questionamentos, definimos como objetivo geral deste estudo o de contribuir para o entendimento dos acidentes de trabalho, a partir de uma perspectiva de análise que privilegia o uso da linguagem para descrever os etnométodos utilizados pelos líderes de uma empresa para explicar os acidentes de trabalho.

Para tanto, propomos os seguintes objetivos intermediários:

(i) Identificar que concepções de senso comum sustentam as explicações que apontam a responsabilidade do trabalhador para os acidentes de trabalho.

(ii) Identificar que concepções de senso comum sustentam as explicações que apontam para outros agentes responsáveis.

No tocante à relevância deste trabalho, inicialmente, deve ser destacada a importância deste estudo no âmbito da área dos Estudos da Linguagem. Como descrito mais detalhadamente na metodologia, procuramos, para a geração de dados, uma empresa cujo negócio envolvesse atividades de risco, a saber, possíveis vazamentos de gás amônia. Durante o processo de apresentação da proposta da pesquisa para a autorização das entrevistas, ocorreram questionamentos por parte dos entrevistados sobre o porquê de uma aluna de Letras estudar um tema, que segundo eles, pertence à área de Engenharia. Responder a esse questionamento, nos leva ao encontro do pensamento de Moita Lopes:

(...) mais importante do que se preocupar com os limites disciplinares ou de uma área de investigação é tentar operar dentro de uma visão da construção do conhecimento que tenta compreender o tópico de pesquisa (construindo o objeto de investigação, portanto) em diálogo com vários campos do conhecimento com o objetivo de integrar perspectivas diferentes que possam melhor cooperar na compreensão da questão estudada (2004, p. 164).

Além disso, o autor aponta que:

(...) a área de estudos da linguagem não deve permanecer isolada de outras Ciências Sociais e Humanas. Acredito que só é possível focar mais adequadamente a linguagem em uso (o que penso ser um de nossos interesses centrais) na contemporaneidade se nos 
familiarizarmos com o que sociólogos, antropólogos, psicólogos sociais e culturais, geógrafos, historiadores, estudiosos da literatura etc. estão apontando sobre a natureza da vida social de nossos dias (2004, p. 165).

Partindo dessa perspectiva, vemos como indispensável olhar o problema dos acidentes através das lentes da linguagem. É nela e através dela que podemos acessar o que é invisível para outras áreas do conhecimento. A pesquisa bibliográfica apontou que há poucas pesquisas realizadas na perspectiva da segurança do trabalho com este recorte, ou seja, com foco na linguagem. Acreditamos que, ao olharmos a questão dos acidentes a partir de uma visão interacional de comunicação em que todos os participantes envolvidos com práticas de segurança são responsáveis por essas ocorrências e ao propormos uma análise focada no princípio da relatabilidade, isto é, no exame das práticas de descrição, relato, explicação para os acidentes, que nos permita conhecer as crenças que sustentam o processo de culpabilização e de desresponsabilização de todos os envolvidos com as práticas de segurança.

Outro fator de relevância diz respeito à literatura sobre responsabilidade e prática profissional. O tema ainda é insuficientemente estudado no âmbito da linguagem, como apontam Anna Solin e Jan-Ola Östman na introdução de um número especial sobre o tema da responsabilidade no Journal of Applied Linguistics and Professional Practice em 2012.

Além dos gaps na literatura, vale ressaltar o perigo de atividades que envolvem o gás amônia, sua toxidade. Conforme comentam Monteiro \& Medani (2015), a insuficiência na implementação da segurança e escassos cuidados com os sistemas de refrigeração, aliados à manutenção inadequada de equipamentos, fazem com que seja rotineira a divulgação de notícias que envolvem vazamentos de gás. Em 2015, em Mineiros, Goiás, 18 trabalhadores foram intoxicados com o vazamento de amônia de refrigeração $(\mathrm{G} 1 \mathrm{GO}, 2015)^{4}$. No mesmo ano, em Rio Verde, Goiás, o mesmo tipo de acidente, 15 funcionários precisaram de atendimento médico após intoxicação devido vazamento de amônia no frigorífico

\footnotetext{
4 Matéria completa disponível em: http://g1.globo.com/goias/noticia/2015/02/vazamento-deamonia-em-industria-intoxica-trabalhadores-em-mineiros.html > Acesso em 04 de fevereiro de 2017
} 
de aves (idem) ${ }^{5}$. No ano de 2016, em outro frigorífico, em Bataguassu, Mato Grosso do Sul, uma funcionária foi hospitalizada após vazamento do gás amônia (G1 MS, $2016)^{6}$. Em 2017, no mesmo frigorífico, 20 funcionários foram intoxicados devido o mesmo problema (G1 MS, 2017) ${ }^{7}$.

O aprofundamento de estudos sobre segurança do trabalho pode trazer inúmeros benefícios para os trabalhadores, como melhores condições de trabalho e proteção à vida; para as empresas, a redução de gastos ligados aos acidentes, como pagamento de taxas e indenizações, interferência na produtividade e gasto com treinamento de novos funcionários; para o governo, a redução de despesas com seguros e pensões; e, finalmente, para a sociedade a diminuição de mortes e sequelas por intoxicações.

Quanto à organização, o estudo se divide em sete capítulos. No segundo, fazemos uma breve revisão da literatura referente à segurança do trabalho e às teorias sobre causas de acidentes. No terceiro, apresentamos o referencial teórico que orienta as análises realizadas. No capítulo quarto, apresentamos a metodologia que adotamos. No quinto, iniciamos a análise dos dados, tendo como foco as explicações que constroem a responsabilização do trabalhador pelos acidentes. No sexto, contemplamos as explicações que apontam para a responsabilidade das empresas para os acidentes de trabalho. No último capítulo, apresentamos as considerações finais, retomando os resultados de pesquisa e esboçando algumas conclusões.

\footnotetext{
5 http://g1.globo.com/goias/noticia/2015/12/funcionarios-de-fabrica-passam-mal-apos-vazamentode-amonia-em-goias.html > Acesso em 04 de fevereiro de 2017

6 http://g1.globo.com/mato-grosso-do-sul/noticia/2016/10/vazamento-de-amonia-assustafuncionarios-de-frigorifico-em-ms.html > Acesso em 04 de fevereiro de 2017

${ }^{7} \mathrm{http} / /$ /g1.globo.com/mato-grosso-do-sul/noticia/2017/02/vazamento-de-amonia-leva-mais-de-20pessoas-para-hospital-em-ms.html > Acesso em 04 de fevereiro de 2017
} 


\section{2}

\section{Segurança do Trabalho}

Neste capítulo, procuramos apresentar temas básicos para o estudo da segurança do trabalho. Na seção 2.1, fazemos um breve relato da história da segurança do trabalho no Brasil. Na seção 2.2, apresentamos uma revisão das teorias mais influentes sobre causas de acidentes de trabalho. Na seção 2.3, dirigimos nosso foco para o significado da cultura da segurança no contexto organizacional. Na seção 2.4, apresentamos o modo como a legislação trata da responsabilidade civil.

\section{1}

\section{Breve histórico sobre a segurança do trabalho no Brasil}

Para falar sobre a história da segurança do trabalho, precisamos primeiro lembrar que o trabalho assalariado, isto é, com remuneração, benefícios e segurança social, surge no Século XX. Até 1888, o Brasil mantinha oficialmente a escravatura, consequentemente, a questão do risco nas ações laborais não era preocupação na época. Só a partir dessa data, essa questão da segurança foi introduzida.

Foi também, no século XX, com o desenvolvimento industrial, que houve um significativo crescimento do número de acidentes de trabalho. Para Giddens (1990), o industrialismo constituiu um dos feixes organizacionais da modernidade. Sua principal característica é constituir uma organização social regularizada que tem como objetivo coordenar atividades humanas, máquinas e aplicações de matérias primas para a produção de bens (GIDDENS, 1990). Contudo, só ao longo desse século, houve uma evolução no tratamento do tema segurança do trabalho e saúde ocupacional.

Em 1919 foi promulgada a lei brasileira $\mathrm{n}^{\circ} 3.724$, a primeira sobre acidentes de trabalho com o conceito de risco profissional ${ }^{8}$. Em 1930, foi criado o Ministério do Trabalho, Indústria e Comércio no governo de Getúlio Vargas e, em 1939, foi oficializada a criação da Comissão Especial de Prevenção de Acidentes, a CEPA,

${ }^{8}$ http://legis.senado.gov.br/legislacao/ListaTextoSigen.action?norma=598133\&id=14426324\&idBi nario $=15798135 \&$ mime $=$ application/rtf $>$ Acesso em 04 de fevereiro de 2017 
de uma empresa de energia elétrica, a Light, pioneira em ações na área de segurança do trabalho.

O marco oficial na prevenção de acidentes de trabalho no Brasil foi a publicação da Consolidação das Leis do Trabalho (CLT), promulgada em $1^{\circ}$ de maio de 1943, por meio do Decreto Lei n ${ }^{\circ} 5.452$, que criava a função dos agentes de segurança 9 .

Posteriormente, entre os anos de 1972 até 1976, iniciou-se a formação dos cursos de engenharia de segurança do trabalho, assim como a figura do médico do trabalho; inspetor de segurança do trabalho, atualmente técnico de segurança do trabalho; enfermeiro do trabalho, atualmente técnico de enfermagem do trabalho e auxiliar de enfermagem do trabalho. Foi criada também o que se denominou a Comissão Interna de Prevenção de Acidentes, mais conhecida como CIPA.

As Normas Regulamentadoras (NRs) surgiram por meio da Lei $\mathrm{n}^{\circ}$ 6.514, publicada em 22/12/1977, com o objetivo de estabelecer os requisitos básicos de prevenção de acidentes e saúde ocupacional dos trabalhadores em todas as empresas estabelecidas em território nacional ${ }^{10}$. Entretanto, como nem todas cumpriam essas normas, foi aprovada, em 1978, por meio da portaria $\mathrm{n}^{\circ} 3.214$, a obrigatoriedade do cumprimento das NRs referentes à segurança e medicina do trabalho ${ }^{11}$.

Ao longo dos anos, essas normas vêm sofrendo atualizações. Uma delas, importante para este trabalho, diz respeito à NR n ${ }^{\circ} 1$ que, através da Portaria ${ }^{\circ} 84$ de 04 de março de 2009, exclui a expressão de "ato inseguro" contida na alínea "b" do item 1.7, assim como os demais subitens que atribuíam ao trabalhador a culpa por um acidente. A alteração não foi menos polêmica do que o conceito. Apesar da ausência da expressão na regulamentação, verifica-se ainda hoje a persistência da crença no ato inseguro como explicação para os acidentes.

Nos anos 80, ocorreram diversos acidentes de grande relevância mundial, como a explosão da nave espacial Challenger e o acidente nuclear de Chernobyl. Em ambos os casos, a explicação foi falha humana, o que levou a implantação de gestões de segurança no intuito de prevenir repetições catastróficas. No Brasil, a

\footnotetext{
9 http://www.planalto.gov.br/ccivil_03/decreto-lei/Del5452.htm $>$ Acesso em 04 de fevereiro de 2017.

${ }^{10}$ http://www.planalto.gov.br/ccivil_03/Leis/L6514.htm> Acesso em 04 de fevereiro de 2017.

${ }^{11}$ http://www.camara.gov.br/sileg/integras/839945.pdf> Acesso em 04 de fevereiro de 2017.
} 
implementação de sistemas de gestão de segurança e saúde do trabalho só se deu na segunda metade da década dos anos 90, o que levou as empresas a introduzirem os Serviços Especializados de Segurança e Medicina do Trabalho (SESMT).

\section{2}

\section{A literatura sobre acidentes de trabalho}

As abordagens dos acidentes, assim como os fatores que constituem a categoria "erro humano", podem ser resumidas em uma visão antiga ou tradicional. Elas detêm-se no comportamento humano como o principal responsável pelos acidentes de trabalho, alegando falta de atenção e percepção de risco, descuido, distração, teimosia, entre outros comportamentos tidos como inadequados. Em proporções controversas, os fatores humanos são predominantemente apontados na literatura como uma das principais causas de ocorrência de acidentes.

Embora sem base científica, porém de grande circulação e peso nas organizações, uma pesquisa feita pela DuPont do Brasil ${ }^{12}$, concluiu que $96 \%$ dos casos de acidentes são decorrentes da ação do ser humano. Entretanto, outros autores (RASMUSSEN, 1997; REASON, 1990) indicam que entre 50 e $80 \%$ dos acidentes são decorrentes de erros sejam eles individuais dos trabalhadores ou daqueles de níveis gerenciais. Somados aos objetivos de produção, fatores como cultura e prioridades influenciam diretamente as decisões sobre direcionamento de recursos para a segurança. Em função disso, o que predomina é a busca por culpados ou por formas de punição ao trabalhador. É comum não se buscar descobrir outras causas envolvidas para a ocorrência do acidente.

A referência clássica dessa visão é o trabalho pioneiro de Herbert William Heinrich, feito na década de 30, para estimativa de custo de acidentes. Segundo o autor, os acidentes de trabalho com ou sem lesões são devidos: à personalidade do empregado, à prática de atos inseguros e à existência de condições inseguras nos locais de trabalho. As proporções entre os tipos de acidentes são de 01 acidente com lesão incapacitante para 29 acidentes com lesões não incapacitantes e 300 acidentes sem lesão.

Para Heinrich (1959), 88\% dos acidentes são provocados por atos humanos

\footnotetext{
${ }^{12}$ http://www.drsrb.dupont.com.br/ >. Acesso em 03 de janeiro de 2018.
} 
inseguros, $10 \%$ por condições inseguras e $2 \%$ por causas fortuitas / imprevisíveis. Com base nisso, propôs a primeira teoria na qual o acidente tem origem em uma sequência linear de eventos, como se fosse um 'efeito dominó', que ele chamou de "Teoria do Dominó". Assim, um acidente não aconteceria, mas seria causado pela sequência de eventos, tais como: (i) personalidade com predisposição para acidentes; (ii) falhas humanas; (iii) atos e condições inseguras; (iv) acidente; e (v) lesão.

O primeiro dominó representa os fatores preexistentes quanto ao caráter do trabalhador. O segundo diz respeito a comportamentos considerados inadequados do trabalhador. A terceira peça representa as atitudes e decisões inseguras e ambiente de trabalho inseguro. $\mathrm{O}$ quarto seria o acidente de trabalho em si e o quinto as lesões de fato resultantes do acidente.

Heinrich introduziu a noção de ato e condição insegura por meio da terceira peça de dominó como fatores imediatamente precedentes ao acidente, ressaltando a associação do comportamento do empregado em relação ao acidente. Segundo o autor, a tendência e o meio social são responsáveis por características como o descuido, a teimosia e outros traços indesejáveis de caráter que, na compreensão de Heinrich, podem ser hereditários e/ou ser desenvolvido pelo meio social. Esta abordagem, considerada limitada, ainda possui uma ampla utilização nos processos de identificação de causas dos acidentes.

Ampliando os estudos de Heinrich, segundo Pontes (2008), Frank Bird revisa o modelo da representação sequencial do dominó e dá continuidade ao estudo, aprimorando estatisticamente a teoria. De 1959 a 1966, o pesquisador analisou, numa única companhia, 90.000 acidentes, sendo 75.000 acidentes com danos à propriedade e 15.000 acidentes com lesões, dos quais 145 se classificaram como incapacitantes. E concluiu que, para cada acidente com lesão incapacitante, ocorriam 100 acidentes com lesões não incapacitantes e outros 500 acidentes com danos à propriedade. Em 1969, Bird aprimora sua Pirâmide e, além de aumentar a amostra, ele inclui o termo quase-acidente na análise. Sua conclusão foi que, para cada acidente com lesão grave, ocorriam 10 acidentes com lesões leves, 30 acidentes com danos à propriedade e 600 quase-acidentes. Os estudos de Bird mostraram um possível caminho a ser trabalhado na prevenção de acidentes que foi o número significativamente alto de quase-acidentes. O problema é quando a estatística é apenas considerada para mesurar futuros gastos com indenizações. 
O Método de Árvore de Causa, surgida na década de 70 (Katsakiori et al., 2009), buscou trazer uma abordagem diferente da Heinrichiana. Inversamente a sequência de Heinrich, é a partir da lesão que se inicia a busca pela causa de acidente. Retrocedendo no tempo, listam-se detalhadamente os acontecimentos que precederam o acidente. A reconstrução detalhada é necessária, pois este método entende que o acidente é resultante de variações ou desvios no processo usual, que podem ser relacionadas por quatro componentes: indivíduo, considerado em seus aspectos físicos e psicofisiológicos; tarefa, entendida como a sequência de operações executadas pelo indivíduo e passível de observação; material, representado por máquinas, instrumentos, ferramentas, matérias-primas e insumos necessários ao desenvolvimento do trabalho e; meio de trabalho, entendido em seus aspectos físicos e em suas relações sociais (BINDER \& ALMEIDA, 1997). Embora essa técnica permita ampliar consideravelmente os conhecimentos a respeito dos fatores que anteciparam os acidentes, pois obriga a pesquisa "das causas das causas" (idem), o que se observa em muitas empresas é o que Oliveira (2007) denomina como uma espécie de "sincretismo teórico", isto é, ideias sistêmicas convivendo com a teoria dos dominós, algo como "construir a árvore de causas para descobrir o que produziu o ato inseguro do trabalhador".

Por sua vez, a Teoria de Propensão ao Acidente buscou explicar a origem dos acidentes pelos aspectos psicológicos. Afirma que algumas pessoas estariam mais propensas a sofrer acidentes do que outras, em virtude de características inerentes ao indivíduo. Essa teoria também coloca nos fatores individuais (traços de personalidade) a responsabilidade pela ocorrência de acidentes de trabalho. Apesar dessa teoria não ser mais considerada uma teoria de base científica, "o conceito difundiu-se através da cultura e atingiu o status de senso comum" (SZASZ apud OLIVEIRA, 1997, p. 35). Dwyer (1991) relaciona a abrangência dessa teoria pela similaridade de sua abordagem com os modelos de produção em massa. Dwyer (2000), por meio da Teoria Social do Erro, afirma que os acidentes de trabalho são produzidos de acordo com os níveis de relações sociais, ou seja, a maneira como trabalhador e o gerenciamento de seu trabalho se relacionam. Esse relacionamento, ele divide em três etapas: recompensa, comando e organização. Pelo primeiro fator, os acidentes são estimulados devido aos incentivos financeiros e simbólicos, que levam o trabalhador a se expor ao risco para alcançar as recompensas. O comando é formado por relações sociais distintas, como o autoritarismo e a servidão 
voluntária. De um lado temos a exigência por produção intensa e do outro a execução das tarefas por meio do medo de punição por não as cumprir. E, organização, o trabalho é produzido por meio do controle exercido sobre a divisão do trabalho. Neste último, Dwyer (1991) faz três divisões, a saber: trabalho rotineiro, falta de qualificação e desorganização. O autor entende que a falta de percepção do risco seria diminuída pelo costume do operário em realizar a mesma atividade; da mesa forma que a baixa qualificação impediria o operário de melhor avalizar os riscos e assim subestimá-los, levando à desorganização das relações do trabalho e, consequentemente, aos acidentes.

Perrow (1999) trouxe o conceito de Normal Acident ou Sistêmico. Para ele, os acidentes são inevitáveis, são 'normais'. Não há o que possa ser feito, o acidente irá acontecer. Para ele, a normalidade do acidente é devido ao ambiente que configura grandes sistemas e que inclui muitos processos, pois há maior probabilidade de ocorrerem interações inesperadas devido a sua complexidade. Segundo o autor, os acidentes ocorrem devido a três tipos principais de problemas: pressões da produção, investigações de acidentes simplistas e redutoras e socialização do risco. Este último diz respeito ao fato de as pessoas estarem expostas ao risco mesmo não fazendo parte diretamente daquela função. Um exemplo, é o do rompimento da barragem da mineradora Samarco, ocorrido em novembro de 2015, que trouxe consequências para a população como lesões e mortes de moradores da região ${ }^{13}$.

Já o modelo do Queijo Suíço, proposto por James Reason (2000), mostra os diversos níveis de defesas e barreiras com função de evitar o acidente e preservar o patrimônio. A teoria indica que todos os sistemas de segurança podem modelar-se como uma série de camadas ou fatias de proteção que se localizam entre os riscos e as pessoas ou ambiente. Dessa forma, as fatias seriam as camadas de proteção, os buracos nas fatias seriam as falhas humanas ou do sistema e, o que passaria por elas seria o risco, resultando-se em acidente ao chegar na última fatia. Em alguns casos, a fatia seguinte poderá interromper o trajeto do acidente em potencial, em outros casos não, pois todas as fatias poderão estar perfuradas, tendo o acidente como resultado. $\mathrm{O}$ ideal seria o processo sem buracos, impedindo o risco e

\footnotetext{
${ }^{13}$ http://g1.globo.com/ciencia-e-saude/noticia/2015/11/rompimento-de-barragens-em-marianaperguntas-e-respostas.html >. Acesso em 03 de janeiro de 2018.
} 
consequentemente o acidente. Por meio dessa teoria, Reason introduziu na literatura os termos falhas/erros ativos e latentes. Segundo o autor as falhas latentes não possuem consequências imediatas e decorrem por resultado de decisões e planejamentos na esfera gerencial. Já as falhas ativas, segundo o autor, são praticadas pelos executores do trabalho, ou seja, os operadores pertencentes a cadeia final de produção, neste caso a consequência do erro é vista como imediata, pois qualquer falha do trabalhador na produção poderia ocasionar um acidente. Este último contribui para o reforço do senso comum da falha humana nas investigações de acidentes.

A partir da revisão da literatura aqui apresentada, podemos perceber que, apesar das variações e da ampliação do ângulo de visão dos acidentes de trabalho, as causas ainda apontam para uma responsabilidade maior do trabalhador. Um interesse nosso neste trabalho é examinar como as explicações para os acidentes retomam para uma ou para várias dessas teorias.

\section{3}

\section{A cultura de segurança no contexto organizacional}

De acordo com Daniellou, Simard \& Boissières (2013 apud LEITE 2015), a expressão cultura de segurança diz respeito às questões de segurança nos meios de trabalho que comportam riscos consideráveis. Em outras palavras, pode-se definir a cultura de segurança como sendo o conjunto de práticas desenvolvidas com o objetivo de identificar e eliminar ou, ao menos, mitigar os riscos no trabalho.

O quadro 1 apresenta definições de cultura por vários autores.

Quadro 1 - Definições sobre cultura de segurança

\begin{tabular}{|l|l|l|}
\hline \multicolumn{1}{|c|}{ AUTOR } & \multicolumn{1}{|c|}{ DEFINIÇÃO } & ANO \\
\hline Cox e Cox & $\begin{array}{l}\text { Refletem as atitudes, crenças, } \\
\text { percepções e valores que os funcionários } \\
\text { partilham em relação à segurança }\end{array}$ & 1991 \\
\hline $\begin{array}{l}\text { International } \\
\text { Safety Advisory } \\
\text { Group a montagem de características e }\end{array}$ & $\begin{array}{l}\text { É a } \\
\text { atitudes nas organizações e nos } \\
\text { indivíduos que estabelecem prioridade e } \\
\text { atenção adequada às questões de } \\
\text { segurança }\end{array}$ & \\
\hline
\end{tabular}




\begin{tabular}{|c|c|c|}
\hline Pidgeon & $\begin{array}{l}\text { Conjunto de crenças, normas, atitudes, } \\
\text { papéis e práticas sociais e técnicas que } \\
\text { estão preocupados em minimizar } \\
\text { exposição dos empregados, gerentes, } \\
\text { clientes e membros do público a } \\
\text { condições consideradas perigosas ou } \\
\text { prejudiciais. }\end{array}$ & 1991 \\
\hline Ostrom et al. & $\begin{array}{l}\text { O conceito de que as crenças e atitudes } \\
\text { da organização se manifestam em ações } \\
\text { políticas e procedimentos, afetando o seu } \\
\text { desempenho em sequranca }\end{array}$ & 1993 \\
\hline Geller & $\begin{array}{l}\text { Em cultura de segurança total, todo } \\
\text { mundo se sente responsável pela } \\
\text { segurança e a persegue em uma base } \\
\text { diária }\end{array}$ & 1994 \\
\hline Berends & $\begin{array}{l}\text { A programação mental coletiva para a } \\
\text { segurança de um grupo de membros da } \\
\text { organização }\end{array}$ & 1996 \\
\hline Lee & $\begin{array}{l}\dot{E} \text { o produto de valores, atitudes, } \\
\text { percepções, competências e padrões de } \\
\text { comportamento, individuais e de grupo, } \\
\text { que determinam o compromisso e o estilo } \\
\text { na gestão de saúde e segurança da } \\
\text { organização }\end{array}$ & 1998 \\
\hline $\begin{array}{l}\text { Kennedy } \\
\text { Kirwan }\end{array}$ & $\begin{array}{l}\text { Um conceito abstrato, que é sustentado } \\
\text { por a amalgamação de indivíduos e } \\
\text { grupos percepções, processos de } \\
\text { pensamento, sentimentos e } \\
\text { comportamentos, que por sua vez dão } \\
\text { origem à maneira particular de fazer } \\
\text { coisas na organização. É um } \\
\text { subelemento do conjunto cultura } \\
\text { organizacional. }\end{array}$ & 1998 \\
\hline Hale & $\begin{array}{l}\text { Refere-se às atitudes, crenças e } \\
\text { percepções compartilhados por grupos } \\
\text { naturais como normas definidoras e } \\
\text { valores que determinam como eles agem } \\
\text { e reagem em relação aos sistemas de } \\
\text { controle de riscos e riscos. }\end{array}$ & 2000 \\
\hline $\begin{array}{l}\text { Glendon } \\
\text { Stanton }\end{array}$ & $\begin{array}{l}\text { Compromete atitudes, comportamentos, } \\
\text { normas e valores, responsabilidades } \\
\text { pessoais, bem como recursos humanos, } \\
\text { como treinamento e desenvolvimento. }\end{array}$ & 2000 \\
\hline Guldenmund & $\begin{array}{l}\text { Os aspectos da cultura organizacional o } \\
\text { que afetará atitudes e comportamentos } \\
\text { relacionado ao risco crescente ou } \\
\text { decrescente. }\end{array}$ & 2000 \\
\hline Cooper & $\begin{array}{l}\text { A cultura é o produto de múltiplos } \\
\text { objetivos dirigidos interações entre } \\
\text { pessoas (psicológicas) empregos }\end{array}$ & 2000 \\
\hline
\end{tabular}




\begin{tabular}{|c|c|c|}
\hline & $\begin{array}{l}\text { (comportamentais) e organizacionais } \\
\text { (situacional); enquanto a cultura de } \\
\text { segurança é esse grau de esforço } \\
\text { observável pelo qual todos membros } \\
\text { organizacionais direcionam sua atenção e } \\
\text { ações para melhorar a segurança } \\
\text { diariamente. }\end{array}$ & \\
\hline Mohamed & $\begin{array}{l}\text { Uma subfacetada da cultura } \\
\text { organizacional, que afeta as atitudes e o } \\
\text { comportamento dos trabalhadores em } \\
\text { relação com a segurança contínua de } \\
\text { uma organização desempenho. }\end{array}$ & \\
\hline Richter e Koch & $\begin{array}{l}\text { Conceitos, experiências e interpretações } \\
\text { de trabalho e segurança - expressou } \\
\text { parcialmente simbolicamente - que } \\
\text { orienta as pessoas ações para riscos, } \\
\text { acidentes e prevenção. }\end{array}$ & 2004 \\
\hline Fang et al. & $\begin{array}{l}\text { Um conjunto de indicadores, crenças e } \\
\text { valores que a organização possui em } \\
\text { segurança. }\end{array}$ & 2006 \\
\hline $\begin{array}{l}\text { Regulamentação } \\
\text { nuclear } \\
\text { Comissão }\end{array}$ & $\begin{array}{l}\text { A cultura da segurança nuclear é o } \\
\text { principal valor e comportamentos } \\
\text { resultantes de um coletivo compromisso } \\
\text { de líderes e indivíduos de enfatizar a } \\
\text { segurança em relação às metas } \\
\text { concorrentes garantir a proteção das } \\
\text { pessoas e meio ambiente. }\end{array}$ & 2011 \\
\hline
\end{tabular}

Fonte: Cole, Kerstan Suzanne; Stevens-Adams, Susan Marie; Wenner, Caren A, 2013.

Desta forma, ilustramos por meio do quadro abaixo a evolução de alguns conceitos que definem a cultura de segurança, a partir dos autores referendados na citação de Cole (et. al, 2013). 
Quadro 2 - Evolução do conceito de cultura de segurança

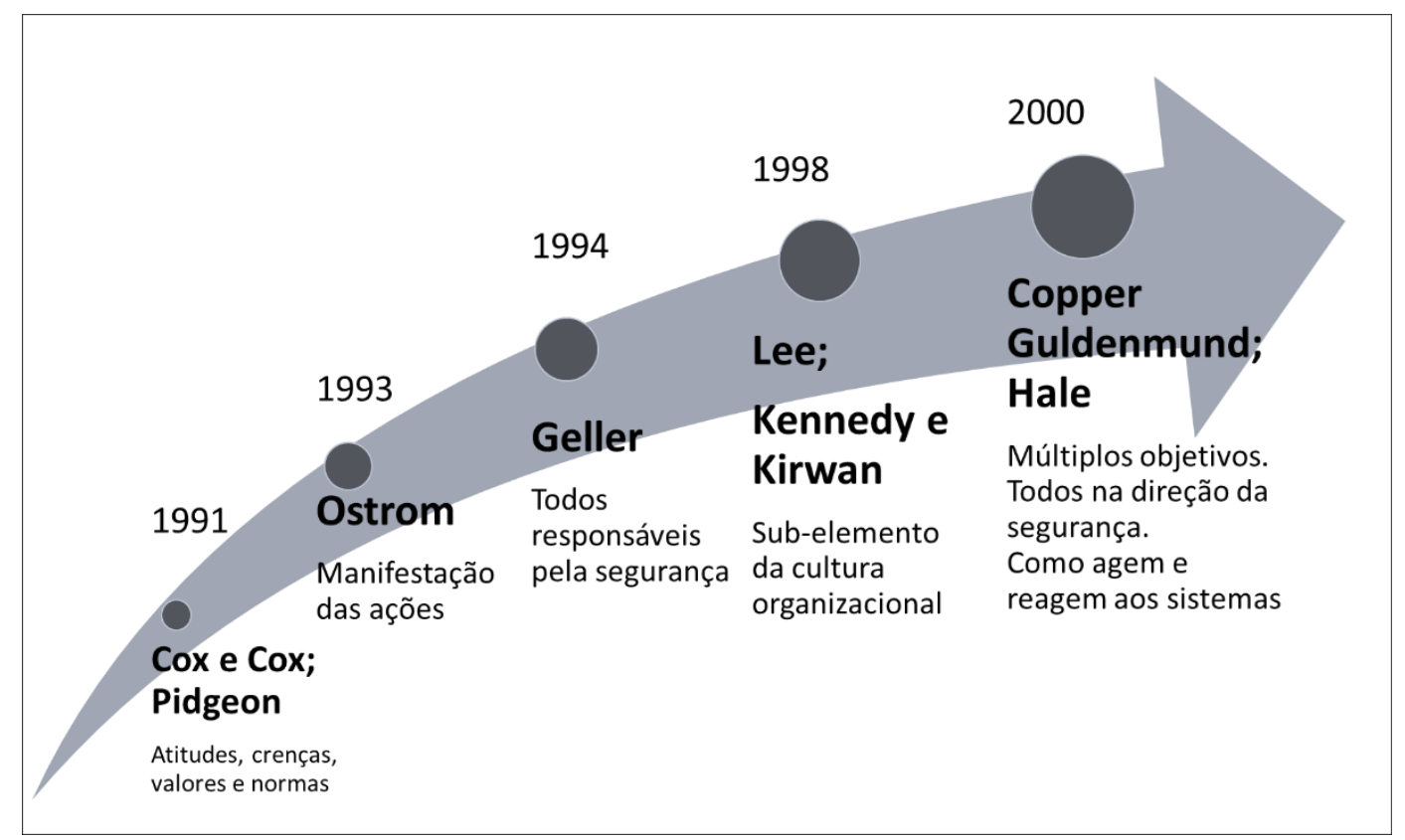

Fonte: a autora

Embora não exista consenso com relação ao conceito de cultura de segurança, há similaridade e convergência entre eles. Um ponto importante é a necessidade de envolvimento de todos os níveis de liderança (ALVES \& JUNIOR, 2013). Não há segurança sem ações políticas por parte da direção, sem compartilhamento de crenças e atitudes que tornem a segurança um valor de todos.

O conceito de liderança, na literatura, tem comumente como foco o modo como um líder deve ser e como ele deve agir. Koontz e O’Donnell (apud HERSEY \& BLANCHARD, 1986, p.104) afirmam que a "liderança consiste em influenciar pessoas para realização de um objetivo comum". Corroborando, Hersey e Blanchard (1986, p.104) afirmam que a liderança é "o processo de influenciar as atividades de um indivíduo ou de um grupo para a consecução de um objetivo numa dada situação". Já para Bergamini (1994, p.109), "a liderança é nitidamente um processo de influenciação que envolve, sobretudo, um ambiente de trocas contínuas entre o líder e seus seguidores". Outro conceito, usado por Bergamini (idem, p. 108), diz que: "líder é aquele que, conseguirá fazer um grupo social consciente dos seus objetivos e valores, capaz de afirmar-se perante seus seguidores e resistir quando sua identidade for ameaçada". E, para Robbins \& Judge (2014, p. 249) "liderança é a capacidade de influenciar um grupo para a realização de uma visão ou conjunto de metas". 
As definições aqui apresentada evidenciam a responsabilidade atrelada às posições de liderança na construção de uma cultura de segurança. Interessa-nos, portanto, examinar que crenças sobre cultura e cultura de segurança emergem nas explicações dadas para a ocorrência de acidentes. Interessa-nos também examinar até que ponto os líderes se autorresponsabilizam de algum modo por possíveis falhas no modo como gerenciam a segurança.

\section{4}

\section{A legislação sobre responsabilidade civil}

Nesta seção, destacamos o modo como a legislação trata a responsabilidade, especificamente dos conceitos basilares de responsabilidade civil subjetiva e objetiva.

\subsection{1}

\section{A tipologia da responsabilidade na legislação}

Duas teorias ou regras gerais operam no tratamento da responsabilidade civil: a da responsabilidade subjetiva e a da responsabilidade objetiva.

\subsubsection{1}

\section{Responsabilidade subjetiva}

Desde a antiguidade, a civilização egípcia, grega e romana, os trabalhos que exigiam mais força bruta eram reservados aos escravos e, mais tarde, às pessoas de classe socioeconômica mais baixa. Em ambos casos, as atividades eram realizadas sem a menor proteção dos trabalhadores.

Nos tempos mais remotos da humanidade, quando a ação danosa ocorria, o reparo era instintivo, por meio da chamada vingança privada, pois não havia regras e regulamentos que pudessem proteger o acidentado. Decorre-se da vingança privada, a Lei da XII Tábuas editada pelos romanos, determinando quais casos seriam vingados pelas próprias mãos.

A ideia de uma responsabilidade civil, data do período entre o final do século III e início do século II a.C, a partir da interpretação "Lex Aquilia de Damno", mais conhecido como "Lex Aquilia", um plebiscito que teve como princípio a aprovação de punição por danos injustamente provocados. Surgia, 
assim, o termo "responsabilidade aquiliana", que se refere à responsabilidade subjetiva, isto é, da indicação da culpa como fator fundamental para a reparação do dano (GONÇALVES, 2011). Dessa forma, nos termos de responsabilidade subjetiva, o responsável é visto como aquele que assume a culpa pelo dano provocado.

A partir do século XVIII, com a revolução industrial, o processo de produção passou a envolver maquinários. Dadas as péssimas condições de trabalho e a falta de ferramentas básicas e equipamentos de proteção individual, cresce o número de acidentes envolvendo os trabalhadores industriais. Foi a Revolução Francesa (1789-1799) que veio frear a exploração industrial iniciada na época (BRANDÃO, 2009), criando regras para indenizações de acidentes de trabalho.

No Brasil, a primeira lei que tratou dos acidentes de trabalho foi o Decreto $\mathrm{n}^{\text {o }} 3.724$ de 1919 que trouxe a garantia de indenização para os acidentados e familiares e a exigência de comunicação do acidente a autoridade policial local. Como avanço, foi expedido em 1934 o Decreto Legislativo $\mathrm{n}^{\circ} 24.637$, que passou a admitir como infortúnio do trabalho toda lesão corporal ou perturbação funcional, ou doença, decorrente do trabalho. Foi admitido também o acidente "in itinere", ou de percurso, quando o acidente ocorre durante o deslocamento de casa para o trabalho e deste para casa. E, em seu artigo 36, ficou estabelecido que os empregadores que não mantivessem contrato de seguro contra acidentes, ficariam obrigados a fazer um depósito na Caixa Econômica Federal ou no Banco do Brasil (MARTINS, 2011).

Contudo, para muitos, o marco da legislação acidentária no Brasil é o Decreto-Lei 7.036, de 10.11.1944, que foi posteriormente regulamentado pelo Decreto $n^{\circ} 18.809$, de 05.05.1945. Esta lei trouxe o regulamento da “concausas" ou causas concorrentes são aquelas que não estão ligadas à atividade laborativa, mas que concorrem com uma causa vinculada ao trabalho, gerando um resultado danoso. Em outras palavras, passou-se a caracterizar como acidente aquilo que tivesse uma relação de causa e efeito sobre o sinistro (morte, perda ou redução da capacidade do trabalhador).

Em 1976, foi editada a Lei $n^{\circ} 6.367$ que definiu que o seguro obrigatório dos empregados sob o regime de previdência social seria realizado pelo Instituto Nacional de Previdência Social (INPS) (MARTINS, 2011). 
Por meio da Constituição de 1988, criou-se a Seguridade Social, ou seja, a contribuição da sociedade ao financiamento da Previdência Social. Em 1991, foi editada a Lei 8.213 que trata dos planos de previdência e delimita o que são considerados acidentes de trabalho e doenças ocupacionais. Esta permanece até os dias atuais com algumas modificações posteriores.

\subsubsection{2}

\section{Responsabilidade objetiva}

Com o desenvolvimento da vida em sociedade, da produção e da tecnologia, não era mais suficiente a teoria da culpa para respaldar o reparo da ação danosa. Surgiram, então, outras teorias para suprir a necessidade, exigida pelo avanço dos grandes centros de produção, de proteger os acidentados. Destaca-se, dentre elas, a teoria baseada no risco criado, cuja responsabilidade independe da culpa, sobretudo conhecida na literatura jurídica como responsabilidade objetiva. Para fundamentar então a responsabilidade sem culpa, essa teoria, também conhecida como teoria do risco, baseia-se no perigo que o desenvolvimento de uma atividade pode representar.

Para a teoria objetiva, o dever de reparar surge com a simples comprovação do dano e uma relação de causalidade entre a ação e este dano causado, em outras palavras, independe de culpa, ela existindo ou não, sempre será irrelevante para a configuração do dever de indenizar.

Diferente da teoria subjetiva, a objetiva fundamenta a responsabilidade por acidentes de trabalho no risco e não mais na culpa. Esse deslocamento provocou uma mudança de uma perspectiva individualista para uma perspectiva social, considerando as interações sociais que circundam o ambiente de trabalho.

Daí a importância da reflexão sobre apuração de responsabilidade, o que se buscará fazer na próxima seção.

\subsection{2}

\section{Apuração de responsabilidades}

Dada a questão da responsabilidade civil na legislação, é padrão, após um acidente, investigar a conduta dos trabalhadores envolvidos, o acidente em si e o nexo causal.É no exame da relação de causa e efeito entre a conduta do trabalhador 
e o resultado produzido, o acidente propriamente dito, que são definidas as responsabilidades. Cabe ressaltar que, por mais que o nexo causal evidencie culpa exclusiva do empregado, mesmo assim será paga uma indenização acidentária pelo Instituto Nacional da Seguridade Social (INSS), devido a sua natureza compensatória e seu benefício ser de cunho estritamente alimentar, assegurando a sobrevivência da vítima e seus familiares.

No entanto, torna-se excludente a responsabilidade civil do empregador, quando é atribuída a culpa exclusivamente à vítima, em função de sua conduta, seja por descaso intencional, quando o funcionário provoca o acidente, seja por culpa consciente, quando o mesmo negligencia orientações dadas pelo empregador para a realização da atividade (GAMBA, 2010).

Outras causas podem isentar a responsabilidade do empregador, como o caso fortuito e força maior (GAGLIANO \& FILHO, 2011). Nessas situações, o acidente ocorre devido a eventos inevitáveis, ainda que previsíveis, aliados à ausência de culpa.

Outro caso diz respeito aos terceiros. Incluem-se aí acidentes que não foram gerados pelos acidentado ou pelo empregador (MANGUALDE, 2008). Um exemplo é o caso da agressão a um funcionário por terceiros.

Assim, não será imputada responsabilidade civil ao empregador, quando o acidente for causado por caso fortuito e força maior, ou por terceiros; ou comprovada a má conduta da vítima quando a situação do empregador em relação às normas legais, técnicas para a prevenção de acidentes então em conformidades.

Além dos casos citados, um modo de responsabilizar os próprios trabalhadores pelos acidentes de que são vítimas é o binômio ato inseguro e condição insegura. Essa crença, apesar das críticas, persiste no modo de pensar dos empresários, profissionais da área e até dos próprios trabalhadores (OLIVEIRA, 2007).

Como vimos no capítulo de revisão da literatura, ato inseguro e condição insegura são conceitos centrais da "Teoria dos Dominós". O comportamento inadequado do empregado somado à presença de condições inseguras levaria a ocorrência do acidente. Apesar dos anos e do surgimento de teorias menos simplistas, essa concepção ainda faz parte do discurso no senso comum dos profissionais de segurança do trabalho, contribuindo para uma forte tendência de 
culpabilizar o acidentado, o que pouco contribui para a efetiva prevenção de acidentes. 


\section{3}

\section{Pressupostos Teóricos}

Neste capítulo, apresentamos os pressupostos teóricos que fundamentaram nossa perspectiva analítica. Na seção 3.1, fazemos uma breve revisão do conceito de responsabilidade. Na seção 3.2, contemplamos os conceitos de relatabilidade (accountability) e de explicações (accounts.).

\section{1 \\ O conceito de responsabilidade}

Niebuhr (1999 [1963] p. 47), em seu livro The responsible self: An Essay in Christian Moral Philosophy, afirma que o termo responsabilidade é "um filho relativamente recém-nascido [...] na família das palavras em que o dever, a lei, a virtude, a bondade e a moral são seus irmãos muito mais velhos". Mas, ainda em suas palavras, "a boca é grande, mas não é responsável por um corpo tão grande"

O certo é que a questão da responsabilidade passou, na sociedade moderna, a ser cobrada de todos, seja nos contextos institucionais, seja nos contextos mundanos. Discute-se hoje a responsabilidade do Estado, do cidadão, da sociedade, dos pais, da escola, enfim de todos os atores sociais em suas diferentes formas de vida. Examinar a responsabilidade desses atores passou a ser uma prática comum na sociedade:

The use of interrogation to reconstruct parts of an individual's past history is a common ocurrence in human affairs. Reporters, jealous lovers, and policemen on the beat are often faced with the task of determining events in another person's life, and the extent to which he was responsible for those events. ${ }^{14}$ (SCHEFF, 1968 p. 3 apud SARANGI,2012: p. 296)

Em sua teoria da responsabilidade, observa-se que Niebuhr (1999 [1963]) retoma alguns aspectos da etimologia da palavra responsabilidade. O termo vem do latim responsus, em sua forma nominativa do particípio passado de respondere,

\footnotetext{
${ }^{14}$ Tradução livre: $\mathrm{O}$ uso de interrogatórios para reconstruir partes da história do passado de um indivíduo é uma ocorrência comum nos assuntos humanos. Os repórteres, os amantes ciumentos e os policiais são muitas vezes confrontados com a tarefa de determinar os acontecimentos na vida de outra pessoa e a medida em que ele foi responsável por esses eventos.
} 
significando responder pelas ações próprias ou dos outros. Como aponta a base etimológica, a responsabilidade é associada ao movimento da orientação de si em relação ao outro, em que o "eu" é formado com base no outro que molda a dimensão relacional.

Essa dimensão relacional é explorada por Sarangi (2012) a partir de Mead (1934). O “eu” é um processo reflexivo socialmente situado, o que é possível graças à percepção da alteridade. Em outras palavras, o "eu" se concebe como o outro deseja que seja concebido. Para Niebuhr, quatro critérios reforçam essa relação de correspondência do "eu" com o outro: (1) resposta, (2) interpretação, (3) accountability $^{15}$ e (4) solidariedade social.

O primeiro elemento é o centro da responsabilidade. De acordo com o autor, toda ação, incluindo o que chamamos indeterminadamente de ação moral, é uma resposta a uma ação sobre nós. É sabido que nos caracterizamos pela consciência, algo aproximado de uma inteligência que identifica, compara, analisa e relaciona eventos, tornando as ações inteligíveis e com significado. Em outras palavras, interpretamos as coisas que possam significar. E, esses padrões de interpretação que empregamos parece determinar, não de forma mecanizada, nossas respostas à ação sobre nós.

Nesse sentido, a resposta está vinculada ao segundo critério proposto, a interpretação, como mostra a ilustração de Niebuhr (1999 [1963] p. 62):

\begin{abstract}
When we think of the relations of managers and employees, we do not simply ask about the ends each group is consciously pursuing nor about the self-legislated laws, they are obeying but about the way they are responding to each other's actions in accordance with their interpretations. Thus, actions of labor unions may be understood better, when we inquire less about what ends they are seeking and more about what ends they believe the managers to be seeking in all managerial actions. One must not deny the element of purposiveness in labor and in management, yet in their reactions to each other, it is the interpretation each side has of the other's goals that may be more important than its definition of its own ends. ${ }^{16}$
\end{abstract}

\footnotetext{
${ }^{15}$ Nesse contexto, estamos entendendo accountability como um modo de tornar inteligível uma ação. No caso em estudo, portanto, seria um ato de prestação de contas.

16 Tradução livre: Quando pensamos nas relações de gerentes e funcionários, não perguntamos simplesmente sobre os fins que cada grupo está perseguindo conscientemente nem sobre as leis auto legisladas que estão obedecendo, mas sim sobre a maneira como eles estão respondendo às ações de cada um de acordo com suas interpretações. Assim, as ações dos funcionários podem ser melhor entendidas quando investigamos menos sobre os fins que estão buscando e mais sobre o que eles acreditam que os gerentes procuram em todas as ações gerenciais. Não se deve negar o elemento de
} 
Nesse sentido, a interpretação não é apenas uma ação responsiva, mas é responsiva de acordo com a nossa interpretação da questão a que estamos respondendo.

O terceiro elemento proposto nessa teoria é o de accountability, ou seja, de prestação de contas. De acordo com o autor, esse termo tem um significado mais definido quando o entendemos em referência a uma parte de um padrão de resposta de nossa auto conduta. Em suas palavras, nossas ações são responsáveis não só na medida em que são reações às ações interpretadas, mas também na medida em que são feitas em antecipação de respostas às nossas respostas. Elas antecipam objeções, confirmações e correções para dar continuidade a interação.

Deste ponto de vista, o autor, tenta iluminar uma questão muito debatida nos tempos modernos: qual a medida em que uma pessoa deve ser responsabilizada socialmente por seus atos? Utilizando o exemplo de um hominídeo, o autor discute essa questão.

Quando um homicídio ocorreu quem deve ser responsabilizado, o próprio assassino ou haverá também responsabilidade por parte da sociedade que atuou como propulsor para o homicídio? O assassino deve ser interpretado unicamente como um ser desobediente à luz da legislação ou deve ser levada em consideração uma interpretação maior de sua conduta - uma que leve em consideração o seu "eu" na sociedade? Dessa forma, o criminoso deve ser entendido como um "eu" que pode antecipar reações a suas ações e, portanto, ser considerado uma pessoa potencialmente responsiva, ou ele deve ser considerado como um ser que não pode aprender a responder com interpretação e antecipação? A educação, a psiquiatria ou o encarceramento são apenas as respostas adequadas?

Em paralelo ao exemplo do autor, nos perguntamos se o trabalhador pode ser o único responsável por determinados tipos de acidente de trabalho. A sociedade e o Estado não teriam responsabilidade pelo baixo grau de escolaridade, pelos ambientes que favorecem a cultura de risco tão familiar aos trabalhadores que executam tarefas que possuem risco? E a empresa? Teria ela a responsabilidade por criar um discurso de segurança que não é manifestado na prática? E os líderes que gerenciam equipes que atuam em tarefas de risco? Poderiam ser responsáveis por

propósito no trabalho e na gestão, ainda que em suas reações mútuas é a interpretação que cada lado tem dos objetivos do outro, que pode ser mais importante do que a definição de seus próprios fins. 
não se preocuparem em avaliar suas práticas de conscientização do risco e da proteção?

A antecipação da reação às nossas reações levou o autor a desenvolver o quarto e último componente significativo da responsabilidade: a solidariedade social. O autor afirma que nossa ação é responsável quando é uma resposta à ação sobre nós em um discurso contínuo ou interação entre os seres que formam uma sociedade contínua. Dessa forma, segundo o autor, a ideia ou padrão de responsabilidade pode ser definido de forma sumária e abstrata como a ideia da ação de um agente como resposta a uma ação sobre ele de acordo com sua interpretação da última ação e com a expectativa de resposta a sua resposta, e tudo isso em uma comunidade contínua de agentes.

O vínculo estabelecido entre agência e estrutura levou Giddens (1984) a propor o conceito de estruturação. Segundo o autor, estrutura e ação estão interligadas, uma vez que as nossas ações moldam e são moldadas pela realidade social. Em outras palavras, as estruturas sociais são moldadas pelas ações dos indivíduos, que, por sua vez, agem de acordo com o conhecimento socialmente estruturado que possuem. Alinhado à ideia de um caráter agentivo dos indivíduos nas interações, Giddens (2005, p. 47) afirma que "temos de moldar nossas vidas de uma maneira mais ativa do que o fizeram as gerações anteriores, e precisamos aceitar mais ativamente responsabilidades pelas consequências do que fazemos e dos hábitos de estilo de vida que adotamos". Apela-se, assim, para a importância da relação agência/responsabilidade e diretamente para a responsabilidade do cidadão, da sociedade.

Para Ahearn (2010) a agência está relacionada à capacidade humana de agir, de forma constitutiva nas estruturas sociais. A autora enfatiza que não podemos entendê-la como sinônimo de livre arbítrio, pois se ignoraria a natureza social da agência e a influência da cultura nas ações humanas, e ou de resistência, por se entender a resistência como uma das formas possíveis de manifestação da agência, já que a manutenção e o reforço do status quo são também possíveis.

Duranti (2004, p. 453), ao propor sua definição de agência, o faz da seguinte maneira:

A agência é entendida como propriedade das entidades (i) que possuem algum grau de controle sobre seus comportamentos, (ii) cujas ações no mundo afetam outras entidades (e suas ações) e às 
vezes a si mesmas, (iii) cujas ações são objetos de avaliação (e.g. em termos de responsabilidade por um dado resultado da ação).

Em outras palavras, a propriedade (i) está relacionada à noção de intencionalidade e também às outras propriedades como poder e avaliação, subtendidas nas propriedades (ii) e (iii). A propriedade (ii) aponta para uma relação de causa, em que a ação afeta outros e a si mesmo; já a propriedade (iii) se vincula à moralidade e performance, em que as ações são avaliadas.

Para Duranti, qualquer ato de linguagem envolve algum tipo de agência, independentemente das intenções do falante ou do interesse do ouvinte, pois, para ele, ao falarmos, estamos criando uma realidade com potencial de afetar os outros, mais especificamente, os ouvintes.

Em sua revisão do conceito de responsabilidade, Sarangi (2012) destaca, além da agência e intencionalidade, o conhecimento e a racionalidade. São esses os quatro pilares para a construção da condição de responsabilidade.

Segundo o autor, a intencionalidade é a pedra angular para imputar responsabilidade e culpa. Em determinadas funções, a responsabilidade é também centro da ação profissional. Em seu exemplo, um policial é dotado da responsabilidade de determinar se em suas investigações quem deve ser responsabilizado por um crime. Do mesmo modo, podemos lembrar que faz parte das ações da área técnica apurar responsabilidade pela ocorrência de um acidente de trabalho.

Outra interface entre esses pilares é estabelecida por Hill e Irvine (1993, p. 2 apud SARANGI, 2012). Para os autores, enquanto a responsabilidade aponta para $\mathrm{o}$ aspecto do significado da agência, as evidências apontam para o aspecto do conhecimento. Portanto, o conhecimento é parte integrante da ação responsável. Podemos aqui lembrar da passagem bíblica em que Cristo isenta de culpa aqueles que o crucificam com seguinte argumento: "Perdoai-os porque eles não sabem o que fazem". Nesse sentido, o conhecimento pode agravar a responsabilidade, como no caso do trabalhador que se acidenta, mesmo sabendo o que está fazendo e o que era para fazer. Se ele tinha o conhecimento, ele deveria ter projetado um cálculo das consequências futuras.

$\mathrm{Na}$ área da linguagem, uma abordagem mais recente é a da responsabilidade relacionada aos papéis assumidos pelos atores sociais (SARANGI, 2012). Grande parte dos estudos sobre papel, na área da linguagem, são inspirados nas 
contribuições de Goffman (1959 [1979]), na área das ciências sociais. Para o autor, o papel é visto como a unidade básica da socialização. E entende o papel social como a "promulgação de direitos e deveres ligados a uma determinada situação social". Como propõe a definição, o tratamento dessa noção em Goffman, é dinâmico, já que é sempre situado. Logo a performance de um papel é o desempenho situado de um papel.

Numa visão mais expandida, Sarangi (2011) distingue três tipos de papel: o papel social, o discursivo e o de atividade. $O$ Papel social se refere às relações entre os participantes. Exemplo: professor e aluno. $\mathrm{O}$ papel discursivo se refere às relações entre os participantes e a mensagem. E o papel de atividade depende da atividade e é definido em relação aos outros.

Em seu artigo "Owning responsible actions/selves: Role-relational trajectories in counselling for childhood genetic testing", Sarangi (2012, p. 295 a p. 318) utiliza a perspectiva da relação de papel para integrar os critérios de agência e intencionalidade. De acordo com seu estudo, as explicações para o teste genético variam de acordo com o papel dos participantes. Os pais explicam sua responsabilidade genética sob a forma de justificativas morais e principalmente causais. Segundo o autor, isso sugere que as explicações dos pais se orientam para o equilíbrio entre vantagens e desvantagens do teste, benefícios do conhecimento para objetivos presentes e futuros, e o trabalho da relação de papel subjacente à decisão sobre o teste. Para os pais, não procurar saber é o ato irresponsável.

No caso dos profissionais, as responsabilidades associadas à tarefa são manifestas no delineamento das vantagens e desvantagens do teste, como a sua inconclusividade, os riscos do saber, o que mostra a orientação desses profissionais para salvaguardar a autonomia e os melhores interesses da criança.

O exemplo evidencia a posição que aqui assumimos sobre o entendimento de responsabilidade. Neste trabalho, vemos responsabilidade como algo construído e dinâmico, na perspectiva do discurso. As identidades não são compreendidas como algo predeterminado e estável, mas sim como coconstruidas e negociadas no discurso, na interação. Ao nos propormos estudar as explicações dadas pelos líderes para a ocorrência de acidentes de trabalho, queremos examinar como a responsabilidade, pode ser assumida, negada ou atribuída a outros, por meio dos detalhes do uso da linguagem e de uma contextualização mais aprofunda. 


\section{2 \\ Os conceitos de relatabilidade e de account}

Nesta seção, apresentamos os dois conceitos teóricos que orientam a nossa análise.

\subsection{1 \\ Relatabilidade}

O conceito de relatabilidade é um dos fundamentos da perspectiva etnometodológica que embasa este estudo. Nas palavras de seu fundador, Garfinkel (2006, p. 1), “os estudos etnometodológicos analisam as atividades cotidianas dos membros como também dos métodos que fazem essas atividades visivelmente racionais e relatáveis a todos os fins práticos, isto é, descritíveis (accountable), enquanto organização ordinária das atividades de todos os dias”.

A proposta de Garfinkel parte da base teórica de Parson, mas com algumas reformulações provindas da influência da fenomenologia de Alfred Schütze Eduard Husserl e o interacionalismo simbólico desenvolvido pela Escola de Chicago, opondo-se à corrente tradicional da sociologia da época (HAGUETTE, 1992).

Diferente de Durkheim, Garfinkel (2006 [1967]) não entende a Sociologia como algo estático e dissociado do contexto, mas sim como uma ciência interpretativista, que tem como objeto os atos sociais que são realizados nas práticas sociais, levando-se em consideração o comportamento dos interagentes seja em contexto coletivo, de grupo ou organização (HERITAGE, 1987; RAWLS, 2008).

Para Alain Coulon (2005), a etnometodologia analisa as ações humanas como fator indispensável para os atos socialmente organizado. Ele afirma que (2005, p.34):

No lugar de formular a hipótese de que os atores seguem as regras, o interesse da Etnometodologia consiste em colocar em dia os métodos empregados pelos atores para 'atualizar' ditas regras. Isso as faz observáveis e descritivas. As atividades práticas dos membros, em suas atividades concretas, revelam as regras e os procedimentos. Dito isso de outra forma, a atenta observação e análise dos processos levados a cabo nas ações permitiriam colocar em dia os procedimentos empregados pelos atores para interpretar constantemente a realidade social para inventar a vida em uma bricolagem permanente. 
Nesta citação, encontramos os pressupostos (HERITAGE, 1987; COULON, 2005 e GARFINKEL,2006) dessa corrente sociológica: a prática (realização); a indicialidade; a reflexividade; accountability (relatabilidade) e a noção de membro. O conceito de prática ou realização compreende as atividades práticas desenvolvidas pelos atores sociais no decorrer de suas ações cotidianas em que sua realidade social é construída na interação e não por um sistema de normas estáveis. Portanto, a etnometodologia busca investigar os métodos criados e utilizados pelos atores sociais que são adaptados a partir das regras. A indicialidade é um termo que se refere a expressões que possuem significados "trans-situacional", ou seja, ao mesmo tempo em que uma palavra possui um significado, a mesma poderá ter sua significação distinta devido a situações particulares, superando seu próprio significado literal e consequentemente ganhando outros significados a partir do conhecimento do contexto local onde elas são produzidas. O conceito de reflexividade está relacionado ao processo de construção contínuo de um grupo, em que a ocorrência de uma ação produz ao mesmo tempo uma reação entre os participantes. A reflexividade designa, portanto, as práticas que ao mesmo tempo descrevem e constituem o quadro social. A relatabilidde (accountability) são as descrições que os interagentes produzem de seus processos reflexivos, buscando evidenciar de forma contínua a constituição da realidade que produziram e experienciaram, tornando as ações compreensíveis e transmissíveis. Segundo Romero (1991) accountability é a explicação que os atores utilizam para descrever, analisar, criticar e idealizar situações específicas. Por fim, a noção de membro. O membro na concepção de Garfinkel está relacionada à condição de "ser" e não apenas "estar" no grupo, conforme Parsons defendia. Dessa forma, membro não se limita a pertencer a um grupo, mas sim, compartilhar a construção social daquele grupo.

Um campo que vem se abrindo para pesquisas de base etnometodológica é o das organizações. Oliveira et al. (2010, p 15) enfatizam que a natureza das organizações é constituída por "produtos de uma realidade socialmente construída a partir das interações dos sujeitos e pautada em um contexto intersubjetivo de compartilhamento de significados", ou seja, os autores apontam para a construção e reconstrução de significados das práticas cotidianas nas organizações.

Olhar as organizações como espaço de construção e criação de significados implica compreender os processos de interações sociais presentes no cotidiano 
organizacional, ou seja, perceber que as práticas significam o aprendizado coletivo em que a cultura, percepção e compreensão do ser não está restrito a um processo cognitivo, mas socialmente construído por meio das interações e da linguagem (GHERARDI, 2006).

Interessa-nos, portanto, conhecer os etnométodos, isto é, o modo como os membros da organização que ocupam lugares de liderança descrevem, analisam criticam as situações de acidentes de trabalho, no que se refere aos conhecimentos de senso comum utilizados para atribuir responsabilidade por esses acidentes.

\section{2 .2}

Account

Muitas vezes, nós nos justificamos, damos explicações ou apresentamos desculpas quando não atendemos às expectativas de alguém em determinadas situações cotidianas. Essas explicações e justificativas por vezes se respaldam em conceitos de ordem moral legal e social para a negociação da avaliação de uma ação (OLIVEIRA, 2017). Uma das funções para a apresentação de razões para determinadas atitudes ou ações é a de esclarecer nossas intenções ou motivos diante a sociedade. Essa situação, John Austin (1979, p. 176 apud WERNECK, 2008) caracteriza como:

(...) aquela em que alguém é acusado de ter feito algo, ou (para deixar mais claro) na qual é dito que alguém fez algo de mau, errado, inepto, indesejado ou desfavorável de alguma entre inúmeras formas. Logo depois, o próprio, ou alguém que esteja a seu lado, tentará defender sua conduta ou tirá-lo da situação.

Para Garfinkel (2006 [1967]), a noção de accounts está relacionada ao fato de que uma ação deve basear-se no senso comum para que faça sentido entre seus interagentes. É nessa perspectiva que buscamos examinar a questão da responsabilidade através das explicações/descrições feitas pelos entrevistados para os acidentes de trabalho.

Para Sarangi (2012, p. 3), accounts não são apenas algo que fazemos com a linguagem, mas são orientados para os outros e têm uma base moral. Muitas têm sido as teorias sobre accounts e a complexidade da tradução desse termo uma vez 
que, dependendo da função apontada nas teorias para os accounts, os significados atribuídos ao termo podem ser muito específicos.

Neste trabalho, destacamos dois entendimentos para o termo. Para Antaki (1988), accounts são “descrições", "explicações comuns” ou autorrelatos" sobre atividades cotidianas. Para Robinson e Boden (2010), um account envolve uma tentativa de um interlocutor de modificar (mudar, explicar, justificar, clarificar, interpretar racionalizar, (re)caracterizar etc), prospectivamente ou retrospectivamente, o entendimento ou avaliação que um interlocutor pode ter de um comportamento em interação em termos de suas possíveis quebras de regras de relevância.

Nessa linha uma das funções reconhecidas para o uso de accounts é a de “construir significados preferidos para eventos problemáticos” (Buttny 1993, p. 21). Essa função aponta para uma das motivações, tratadas por Goffman (1959), para recorrer ao uso de account: o trabalho de gerenciamento de imagem implicada na noção de auto-apresentação. Para esse autor (1967 [1956]), accounts são produzidos no sentido de proteger a face em decorrência de algum comportamento considerado problemático por seus interagentes. Trata-se de um trabalho de elaboração da face (facework). No caso de acidentes de trabalho, por exemplo, empresa ou empregado buscam, diante de tal ocorrência, encontrar meios de proteger suas imagens para que não sejam vistos como negligentes, incompetentes, ou atributo negativo.

Também para Scott e Lyman (1968, p. 46), accounts servem para explicar comportamentos inesperados, imprevistos, impróprios, indesejáveis. Para tanto, eles distinguem dois tipos principais de accounts, desculpa e justificativa/ou justificações (excuses), em que a responsabilidade é o elemento diferenciador:

Justificativas são accounts em que alguém aceita a responsabilidade pelo ato em questão, mas renega a qualificação pejorativa associada a tal ato. [...] Desculpas são accounts em que alguém admite que o ato em questão seja ruim, errado ou inapropriado, mas nega ter plena responsabilidade sobre ele (idem, p. 141).

No caso das desculpas, os autores propõem quatro tipos, que são: apelo a acidentes, apelo à anulação, apelo a determinações biológicas e uso de bode expiatório. Apelo a acidentes são desculpas que colocam os acidentes 
(humanamente incapaz de serem controlado) como o causador de um comportamento indevido e, assim, a responsabilidade da pessoa é suavizada. Apelo à anulação corresponde ao tipo de desculpa em que se alega falta de conhecimento como forma de defesa. Apelo a determinações biológicas busca atenuar a culpa apelando para a própria condição do ser humano, que, não sendo capaz de controlar impulsos, comete erros naturalmente. E, por fim, bode expiatório refere-se ao ato de o indivíduo afirmar que o comportamento inadequado foi realizado em resposta à atitude ou comportamento de outro alguém, o que implica a transferência da responsabilidade para essa outra pessoa.

Buttny (1993, p. 1) se alinha e amplia o entendimento dos accounts como “explicações”, “escusas”, “justificativas”, “desculpas”, “desmentidos”, “defesas verbais", "exposição de motivos", entre outros. Mantém-se, assim, o entendimento de que accounts são usados "para construir interacionalmente os significados preferidos para eventos problemáticos" (idem, p. 21).

O autor sugere três funções para o uso dos accounts, que são: (i) preservação da face dos interagentes, (ii) manutenção das relações sociais e (ii) controle social. A (i) se refere à imagem positiva que as pessoas reivindicam para si e que é negociada nas interações, para obter a aprovação por parte dos outros. A (ii) diz respeito à reconciliação do comportamento antes visto como problemático e não aceitável moralmente. Segundo Buttny, os accounts servem como lubrificantes das relações sociais. E, por fim, a terceira (iii) os accounts têm a função de orientar e dosar o comportamento para o controle social.

A partir da releitura das "técnicas de neutralização" (SYKES e MATZA, 1957 apud SCOTT e LYMAN (2008 [1968]), os autores propõem também a ocorrência de quatro tipos possíveis de justificativas, são elas: as técnicas de negação do dano, negação da vitimização, condenação dos condenadores e apelo à fidelidade. Pela técnica de negação do dano, o interagente afirma que praticou um ato não esperado, causando atrito, mas que tal ato é aceitável, visto que não é ou não foi prejudicial a ninguém. Na negação da vitimização, o responsável pela ação reconhece que esta foi admissível, já que a vítima reivindicou de forma coerente o dano provocado por ele. Na condenação dos condenadores, o ator social se responsabiliza por ter realizado o ato, entretanto, afirma que, embora tenha feito tal ação, outras pessoas que o acusam cometeram atos mais graves e ainda assim 
permaneceram ilesas, sem julgamentos. E, por último, pelo apelo à fidelidade, o agente avalia a ação como aceita, visto ter sido feita em benefício do outro.

Embora nesta pesquisa não estejam sendo ouvidos aqueles que realizam as tarefas que envolvem alto risco, supõe-se que alguns desses tipos de accounts ocorram com a função de desresponsabilizar a liderança pela ocorrência de acidentes. Outro ponto importante a ser destacado nas contribuições de Scott e Lyman (2008 [1968]) é a possibilidade de examinarmos como o meio social emerge nessas explicações. De acordo com os autores, quando um indivíduo interage com outro, o indivíduo socializado tem como bagagem cultural um repertório de expectativas prévias, que funcionam como conhecimentos que servem para filtrar aquilo que é aceitável ou não como um account.

Apesar dos estudos realizados por Scott e Lyman terem sidos fundamentais para o desenvolvimento da compreensão dos accounts, muitas são as críticas sobre a descontextualização dos dados utilizados, uma vez que foram baseadas em situações abstratas (ANTAKI, 1994 apud ARRIBAS-AYLLON, SARANGI e CLARKE, 2011). Mas, apesar das críticas, o desenvolvimento dos estudos sobre accounts trazem de um modo geral algumas referências àqueles estudos.

Billig (1996), por exemplo, vai explorar o uso retórico dos accounts. Sua tese é a de que a retórica não deve se limitar a uma comunicação argumentativa ou persuasiva, mas vista como uma atividade socialmente generalizada. É a partir desse pressuposto, que ele defende que accounts exemplificam o tipo de atividades em que os argumentos são fornecidos para explicar a inconsistência entre atitudes e ações. Isso amplia a visão de account como uma forma de prevenção de conflito. Para o autor, quando um indivíduo usa um account ele está lançando mão de uma estratégia argumentativa para a realização de uma ação retórica: a de defender um posicionamento.

Neste trabalho, queremos examinar que conhecimentos de senso comum são invocados nas explicações para acidentes de trabalho e que funções realizam e como a questão da responsabilidade emerge nessas explicações. 


\section{4}

\section{Pressupostos Metodológicos}

Durante todo o período de geração de dados, após cada entrevista, vinha à minha mente, de modo cada vez mais forte, a afirmação de Nietzsche:

Até que a palavra "conhecimento" tenha sentido, o mundo é cognoscível; mas este é interpretável de modos diversos, e não existe nele um sentido, mas inumeráveis sentidos. ${ }^{17}$

São várias as interpretações de mundo quando relatamos algumas histórias, contamos fatos ou descrevemos situações, por isto, "não há nunca, para Nietzsche, um significado original" (FOUCAULT, 1967, p. 190 apud CAMARGO, 2008), o que torna a tarefa do interpretar uma tarefa infinita (idem, p. 187). Nossa intenção aqui não é trazer um estudo sobre a verdade, ou melhor, "a vontade de verdade" como Nietzsche discorre magnificamente em sua obra, mas trazer à análise as interpretações dos participantes da pesquisa sobre acidentes de trabalho. A discussão sobre o que é um acidente de trabalho, por que os acidentes ocorrem e quem é responsável por um acidente abre a possibilidade de infinitas interpretações.

No intuito de conhecer essas interpretações, tomamos decisões teóricometodológicas que apresentamos neste capítulo. Na seção 4.1, caracterizamos a natureza da pesquisa. Na seção 4.2, relatamos o processo de construção do contexto da pesquisa. Na seção 4.3, focalizamos o processo de geração de dados e participantes. E finalmente, na seção 4.4, descrevemos os procedimentos analíticos.

\section{1}

\section{A escolha do método}

Esse trabalho se alinha à pesquisa de natureza qualitativa e interpretativa. Qualitativa pelo seu caráter transfronteiriço, em outras palavras, ela não se limita, adentra a investigação do subjetivo do objeto, de suas particularidades, considerando suas experiências e o mundo que o cerca, neste sentido, como afirmam Denzin \& Lincoln (2006, p.17), “a pesquisa qualitativa é, em si mesma, um campo de investigação", vista sua abordagem empírica, "ela atravessa

\footnotetext{
${ }^{17}$ Nachlass/FP 1886-1887, 7[60], KSA 12.315.
} 
disciplinas, campos e temas" (idem). E, interpretativa, visto que, o interpretativismo é uma "tendência epistemológica que aposta justamente na impossibilidade de generalização, tipificação e objetividade" (BIAR, 2009, p. 5).

Como afirma Moita Lopes (2004, p. 166), a "complexidade do mundo social só pode ser focalizada se hibridizarmos nossas teorias e metodologias, constantemente em contato com outras áreas do conhecimento. Estudar acidentes de trabalho em ambientes de alto risco é por si só uma questão que entrelaça áreas como a engenharia, a sociologia, a psicologia, o direito, a segurança do trabalho, além da área da linguagem.

Do mesmo modo, a pesquisa interpretativista oferece a possibilidade de diferentes representações e pontos de vista sobre o mundo. Os fenômenos de interesse central deste trabalho são os processos da produção de sentido subjacentes à construção da responsabilidade em acidentes de trabalho por parte dos que são responsáveis pelos "chão de fábrica". Logo, acreditamos, que a natureza interpretativista da pesquisa permite um melhor entendimento e aprofundamento das diferentes percepções sobre o problema em estudo.

Apesar de essas abordagens permitirem a compreensão das realidades sociais estudadas, bem como dos processos de criação de situações sociais, construção de significados e estruturas discursivas, ainda existem questionamentos acerca do seu caráter científico. Há muitos estudiosos, porém, que compreendem a complexidade desse método, destacando a sua relevância em pesquisas acadêmicas. Minayo (2017), por exemplo, reconhece que as abordagens quantitativas e qualitativas têm natureza diversa: a primeira trata da magnitude dos fenômenos, a outra, da sua intensidade; uma busca aquilo que se repete e pode ser tratado em sua homogeneidade, a outra, as singularidades e os significados (idem). Mas, ressalta, a diferença de natureza não implica que a abordagem qualitativa esteja isenta de parâmetros e normas que possam dar-lhe status de cientificidade.

\section{2}

\section{As escolhas do universo e da amostra da pesquisa}

Data motivação apresentada na introdução desse estudo, inicialmente a pesquisa surgiu com o desejo de desenvolver um projeto para uma empresa cujo negócio envolvesse atividades de risco e que sua política interna fosse respaldada 
na filosofia de "acidente zero". Contudo, como caraterística fundamental da empresa, para a possibilidade de geração de dados, era necessário que a mesma tivesse interesse no estudo que, por ser de base linguística, pudesse trazer novos entendimentos sobre a questão dos acidentes de trabalho e com isso uma revisão dos programas de prevenção de acidentes. Em princípio isso foi alcançado.

Depois de longos meses de contato por e-mail e telefone com uma empresa de energia elétrica, situada no Brasil, no dia 12 de maio de 2017 foi apresentado este estudo como projeto de pesquisa durante uma reunião com dois responsáveis pela saúde, segurança, meio ambiente e qualidade da empresa, sendo um responsável pelas unidades situadas no Rio de Janeiro, Ceará e Goiás, e outro, mais especificamente, com os funcionários do Rio de Janeiro. Houve um grande interesse no estudo, inclusive com o pedido de extensão da pesquisa para além da unidade do Rio de Janeiro.

No entanto, entraves burocráticos e jurídicos atrasaram a geração imediata dos dados, o que impulsionou a realização de entrevistas pilotos com amigos e familiares que trabalhavam em atividade de risco iminente, de diversos seguimentos, como energia e petróleo.

A iniciativa permitiu não só uma aproximação com esse universo de pesquisa, um aprendizado como entrevistadora e pesquisadora, mas principalmente a oportunidade de conhecer uma engenheira de saúde e segurança funcionária de uma indústria de distribuição e logística. A entrevista com a engenheira se deu no seu local de trabalho e, para minha surpresa, outros engenheiros e responsáveis se dispuseram a contribuir com a pesquisa. Com isso, a amostra começou a ser construída, parte do universo de pesquisa, que, mesmo não envolvendo a direção da empresa, atendia aos interesses do estudo.

O estudo desenvolveu- se numa empresa situada na região metropolitana do Rio de Janeiro, atuante no segmento de distribuição e logística, que opera para todo Brasil. Suas atividades, desde a década de 90, são focadas no fornecimento de gêneros alimentícios. O serviço consiste na compra, armazenamento, manipulação e entrega dos produtos em grande volume. O centro de distribuição armazena alimentos congelados e secos. Para esses armazenamentos, na refrigeração, são utilizados nas câmaras frigoríficas o gás amônia.

A amônia é um gás de odor forte, incolor e tóxico à saúde. Dependendo do tempo de exposição, pode provocar queimaduras severas à pele e às mucosas 
(VALE, 2012). Quando inalada, pode provocar sintomas alérgicos, de asma, broncoespasmo, queimadura da mucosa nasal, faringe e laringe, dor no peito e edema pulmonar e outras dificuldades respiratórias, além disso, reações tardias podem acontecer, como catarata, atrofia da retina e fibrose pulmonar (VALE, 2012).

Devido sua toxidade aliada a necessidade de utilização na refrigeração e consequentemente exposição dos trabalhadores a este gás tornou-se vital a realização desse estudo.

\section{3}

\section{A geração de dados}

Neste trabalho, adotamos a nomenclatura "geração de dados" "por entendermos que a vida social que nos interessa compreender é em si evanescente e que não pode ser captada integralmente por nenhum aparelho ou método de gravação" (GARCEZ et al., 2014, p. 262). Além do mais, acreditamos na não existência de dados prontos à priori em pesquisa qualitativa, uma vez que entendemos que a situação social de entrevista é situada e coconstruída entre o entrevistado e o entrevistador.

O método de geração de dados desta investigação compreendeu na realização de entrevistas cujo tema versou sobre os aspectos que, na opinião dos indivíduos influenciam a ocorrência de acidentes. Para tanto, foram formuladas perguntas genéricas em torno de tópicos, como: A seu ver, qual é a responsabilidade do acidentado no acidente? Como você acha que as empresas costumam explicar os acidentes? Sobre os procedimentos de segurança, alguém reclama em realizar os procedimentos, em utilizar algum tipo de equipamento mesmo sabendo que é para proteção? Na sua percepção, como você imagina que o risco é entendido pelos níveis operacionais mais baixos e pelos superiores, existe alguma diferença? Você já presenciou alguém se recusando a realizar algum tipo de serviço devido ao risco?

A seleção dos participantes se deu a partir, primeiramente, do critério de acessibilidade e de vínculo profissional com a segurança do trabalho. Outro critério foi o da posição hierárquica. Demos preferência àqueles que se encontram mais próximos do "topo da pirâmide", isto é, os que coordenam, supervisionam ou de outra forma estão relacionados aos que lidam diretamente com o risco. 
Justifica-se o recorte feito por duas razões. A primeira diz respeito ao fato de que grande parte da literatura sobre acidentes de trabalho responsabiliza unicamente o empregado por essas ocorrências. Considerando-se isso e o fato de que a literatura sobre liderança afirma que liderar "é a capacidade de exercer influência sobre indivíduos e grupos” (VERGARA, 2009, p. 74), interessou-nos examinar até que ponto essas pessoas se viam também responsáveis pelos acidentes.

Nessa linha, foram entrevistados um gerente e dois engenheiros de segurança do trabalho. Procurou-se também entrevistar profissionais de áreas afins, como um enfermeiro de saúde e segurança do trabalho, e um professor do curso de segurança do trabalho de uma escola técnica. Nosso interesse no profissional de saúde deve-se ao fato de que é um profissional que participa de todo o processo que envolve o acidentado. Quanto ao educador, buscamos conhecer como a questão da responsabilidade por acidentes de trabalho é tratada no processo de formação daqueles que vão liderar os que trabalham em atividades de risco iminente.

Apresentamos a seguir um breve perfil dos participantes. A fim de preservar suas identidades, foram dados aos entrevistados nomes fictícios.

- Felipe: Homem, casado, formado em engenharia mecânica, pós-graduado em engenharia de segurança do trabalho, também trabalha como professor universitário em curso de pós-graduação em engenharia de segurança do trabalho. No momento, exerce a função de gerente coorporativo de saúde e segurança, sendo responsável pela integração das informações das empresas que prestam serviços para a sua empresa de origem.

- Rita: Mulher, casada, formada em engenharia de alimentos, pós-graduada em segurança do trabalho. Atualmente trabalha como engenheira de saúde e segurança do trabalho, é contratada pela mesma empresa em que o Felipe é o gestor.

- João Pedro: Homem, casado, formado em gestão ambiental, pós-graduado em segurança do trabalho, meio ambiente e saúde. Atualmente trabalha como engenheiro de saúde e segurança do trabalho, é contratado de em uma das empresas que prestam serviços para a empresa em que o Felipe gerencia. 
- Robson: Homem, casado, formado em enfermagem, pós-graduado em enfermagem do trabalho e emergência pré-hospitalar. Atualmente trabalha como enfermeiro do trabalho, é contratado da mesma empresa do João Pedro, dando suporte às demais empresas. Acompanha as análises de acidentes, os afastamentos e as reintegrações dos trabalhadores que sofreram acidentes.

- Emerson: Homem, casado, formado em ciências sociais, especialização em filosofia tendo, posteriormente, concluído o curso técnico em segurança do trabalho. Atualmente trabalha como professor em curso de formação técnica em segurança do trabalho e é atuante da CIPA na instituição de ensino que leciona.

A entrada no campo se deu, inicialmente pela seleção dos os participantes, conforme critérios anteriormente mencionados, junto à autorização do gerente da área, que de primeiro momento, estranhou o interesse da pesquisadora em um assunto que, segundo sua percepção, pertence a área de Engenharia e não de Letras. Dado questionamento, foi esclarecido o propósito da pesquisa e sua interdisciplinaridade.

As entrevistas com o gerente, os dois engenheiros e o enfermeiro do trabalho ocorreram no dia 26 de junho de 2017, individualmente e tiveram a duração aproximada de uma hora para cada entrevistado. A entrevista com o professor Emerson ocorreu quatro dias após as entrevistas anteriormente citadas, 30 de junho de 2017, com duração aproximada de uma hora.

Após a gravação das entrevistas, os dados foram transcritos. A transcrição foi feita com base nos símbolos utilizados por Sacks, Schegloff e Jefferson ([1974] 2003).

\section{4}

\section{A escolha do procedimento analítico}

Tendo em vista o alcance do objetivo geral que é o de contribuir para o entendimento dos acidentes de trabalho, a partir de uma perspectiva de análise que privilegia o uso da linguagem para descrever os etnométodos, isto é, o modo como 
os membros da liderança descrevem, interpretam e constroem o mundo social, especificamente, neste trabalho, os acidentes de trabalho. Para tanto, em uma primeira etapa, analisando as falas dos entrevistados buscando localizar todas as explicações oferecidas para justiçar acidentes. Em uma segunda etapa, trabalhamos sobre os fragmentos selecionados, buscando identificar os alvos, isto é, aqueles que são responsabilizados pelos acidentes.

Em uma terceira etapa, examinamos como a responsabilidade é construída na perspectiva do discurso, identificando traços discursivos, categorias de palavras que apontam para os pilares da responsabilidade, como agência, conhecimento, intenção, racionalidade. Finalmente, identificamos as crenças que sustentam o processo de culpabilização, procurando relacionar essas crenças às teorias tradicionais sobre causas de acidente de trabalhado.

Desta forma, ilustramos, por meio do quadro abaixo, o fluxo do procedimento analítico anteriormente citado.

Quadro 3 - Fluxo do procedimento analítico

SELEÇÃO DOS FRAGMENTOS DE FALA EM QUE OCORREM EXPLICAÇÕES

\section{ORGANIZAÇÃO DAS EXPLICAÇÕES EM TERMOS DOS ALVOS DA CULPABILIZAÇÃO}

IDENTIFICAR ELEMENTOS LINGUÍSTICOS-DISCURSIVOS QUE OPERAM NA CONSTRUÇÃO DA RESPONSABILIDADE

\section{IDENTIFICAR AS CRENÇAS QUE SUSTENTAM AS EXPLICAÇÕES}

Fonte: a autora. 


\section{A Vítima como Responsável}

Este capítulo tem como foco as explicações para os acidentes que reafirmam as concepções de senso comum de ato inseguro. Assim, os trabalhadores são vistos como os principais responsáveis pelos acidentes.

Considerando que essas explicações são aquelas defendidas na Teoria dos Dominós, dividimos este capitulo em duas seções. Na seção 5.1, examinamos as explicações que remetem ao que Heinrich (1959) estabelece como a primeira peça do dominó, a personalidade, isto é, os fatores sociais e ambientais prévios responsáveis pela formação do caráter dos operários que causam o acidente. $\mathrm{Na}$ seção 5.2, focalizamos as explicações que apontam para a segunda peça do dominó, isto é, os comportamentos inadequados dos trabalhadores, os chamados comportamentos de risco.

\section{1}

\section{A primeira peça do dominó}

A análise das explicações para acidentes, sustentadas por fatores sociais e ambientais prévios, revela não só a responsabilização do próprio trabalhador pelo evento de que foi vítima, mas também a desresponsabilização da empresa e das lideranças envolvidas com a gestão da segurança pelos acidentes. Como veremos na análise, de acordo com os entrevistados, todos fazem a sua parte. Quem não faz é o empregado.

Uma questão central no processo de responsabilização é a agência. Mas, como adverte Ahearn (2010), ela não é sinônimo de livre arbítrio, pois estaríamos ignorando a sua natureza social e a influência da cultura nas ações humanas.

Entende-se que ao apelarem para a explicação dos acidentes como relacionada ao fato de o trabalhador ser membro de uma cultura em que segurança não é um valor, os entrevistados estariam atribuindo uma responsabilidade relativa a esse trabalhador, porque veem sua agência como manutenção e o reforço do status quo (AHEARN, 2010).

Robson, por exemplo, mostra que, ao buscarem uma escola para os filhos, os pais valorizam o que essa escola ensina, a metodologia, as opções de atividades 
extracurriculares, mas não avaliam as condições de segurança. Num exemplo mais enfático, cita o caso das faculdades que oferecem cursos de segurança no trabalho:

\section{Excerto 1: não é cultura (observar a segurança)}

\begin{tabular}{|l|l|l|l|l}
\hline 60 & ROBSON: & arriscado você ir pra faculdade de engenharia de \\
61 & & segurança (.) e chegar lá o cara >aquilo que eu te \\
62 & & falei< as portas não estão em conformidade (.) a \\
63 & & estrutura das portas a abertura das portas os \\
64 & extintores não estão dimensiona:ados não existe \\
65 & rota de fuga (.) você tem um prédio de dois andares \\
66 & que só tem uma escada e aí não é cultural \\
\hline
\end{tabular}

Ao mesmo tempo em que esse argumento atenua a responsabilidade dos trabalhadores, uma vez que segurança não é uma prática no cotidiano, ele serve para desresponsabilizar os gestores com relação à tarefa de conseguir que esses trabalhadores sigam normas de segurança na empresa.

\section{Excerto 2: como é que você vai criar uma cultura (de segurança)}

\begin{tabular}{|l|l|l|}
\hline 110 & ROBSON: & aí você pega um cara desses que tá acostumado a \\
111 & & vida inteira a andar de ônibus sem cinto e vai ser \\
112 & & um dia (.) o motorista do carro da empresa (.) ué \\
113 & no ônibus eu não uso cinto por que aqui eu tenho \\
114 & que usar não te:em $\uparrow$ como é que você vai criar uma \\
115 & \\
116 & cultura não existe (.) não vem de berço (.) como \\
117 & & é que você (.) vai pegar o cara burro velho e vai \\
118 & incutir na cabeça dele de que a segurança tem que \\
& ser assim \\
\hline
\end{tabular}

Na percepção de Robson cultura é algo fixo, imutável; a cultura do berço é a dominante ( como é que você vai criar uma cultura não existe (.) não vem de berço - linhas 114, 115). De acordo com essa crença, as lideranças estariam impossibilitadas de desenvolver a cultura da segurança (como é que você (.) vai pegar o cara burro velho e vai incutir na cabeça dele de que a segurança tem que ser assim-linha 115 a 117).

Na mesma linha, outro entrevistado explica os acidentes:

\section{Excerto 3: culturalmente nós não temos uma consciência}

\begin{tabular}{|l|l|l|}
\hline 97 & AMANDA: & como conscientizar isso é difícil né? \\
\hline 98 & JOÃO PEDRO: & só treinamento (.) palestra (.) diálogo de \\
99 & & segurança assim de manhã >cinco dez minutinhos \\
100 & & reúne todo mundo conversa< diz a importância \\
101 & & mas isso é é como eu disse é trabalho de \\
102 & & formiguinha (.) é uma coisa que vem com o tempo \\
103 & & como eu te disse cululturalmente nós não temos \\
\hline
\end{tabular}




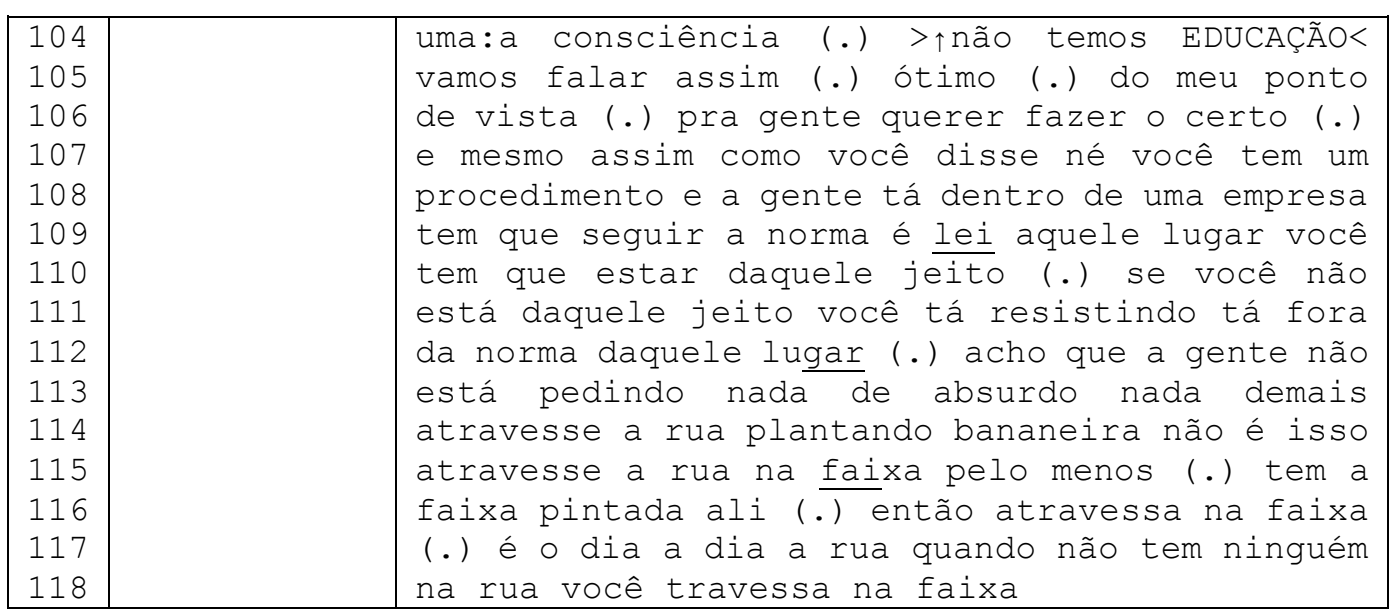

João Pedro inicia sua fala trazendo evidências de que empresa e liderança fazem a sua parte (só treinamento (.) palestra (.) diálogo de segurança assim de manhã >cinco dez minutinhos reúne todo mundo conversa< diz a importância - linha 98 a 100). E por meio de uma metáfora "trabalho de formiguinha" (linhas 101 e 102), evidencia o seu compromisso com o desenvolvimento da cultura de segurança, mas ao mesmo tempo, o quanto os resultados desse trabalho podem ser lentos. E a sua explicação é mais uma vez a questão cultural (como eu te disse cu:ulturalmente nós não temos uma:a consciência (.) >^não temos EDUCAÇ̃̃o<- linhas 103 e 104).

A atenuação da agência vem da pressuposição de que ao repetirmos padrões com base no que aprendemos como membros de uma cultura, torna-se mais difícil projetar um cálculo de consequências futuras. A falta desse cálculo explicaria o ato inseguro.

Diferentemente de Robson, João Pedro aponta outra forma de agência do trabalhador: a resistência (AHEARN, 2010). É, assim, que ele explica a dificuldade de convencer o trabalhador a seguir as regras (se você não está daquele jeito você tá resistindo - linhas 110 e 111).

Assim como não reconhecem que a cultura e os aspectos a ela vinculados são resultados de construções socioculturais, os entrevistados também ignoram que as identidades resultantes desse processo não são coisas com as quais nós nascemos, mas são formadas e reformadas ao longo da vida (VIEIRA et.al., 2002)

Em função dessa visão, uma das explicações para os acidentes é a identidade daqueles que vivem numa cultura de risco, como mostra o excerto 4. 


\section{Excerto 4: como herói que ele é}

\begin{tabular}{|c|c|c|}
\hline $\begin{array}{l}45 \\
46 \\
47 \\
48\end{array}$ & AMANDA: & $\begin{array}{l}\text { sobre os procedimentos de segurança (.) alguém } \\
\text { reclama em realizar em utilizar algum tipo de } \\
\text { equipamento mesmo sabendo que é (.) pra proteção } \\
\text { dele }\end{array}$ \\
\hline $\begin{array}{l}49 \\
50 \\
51 \\
52 \\
53 \\
54 \\
55 \\
56 \\
57 \\
58 \\
59 \\
60 \\
61 \\
62 \\
63 \\
64 \\
65\end{array}$ & EELIPE: & 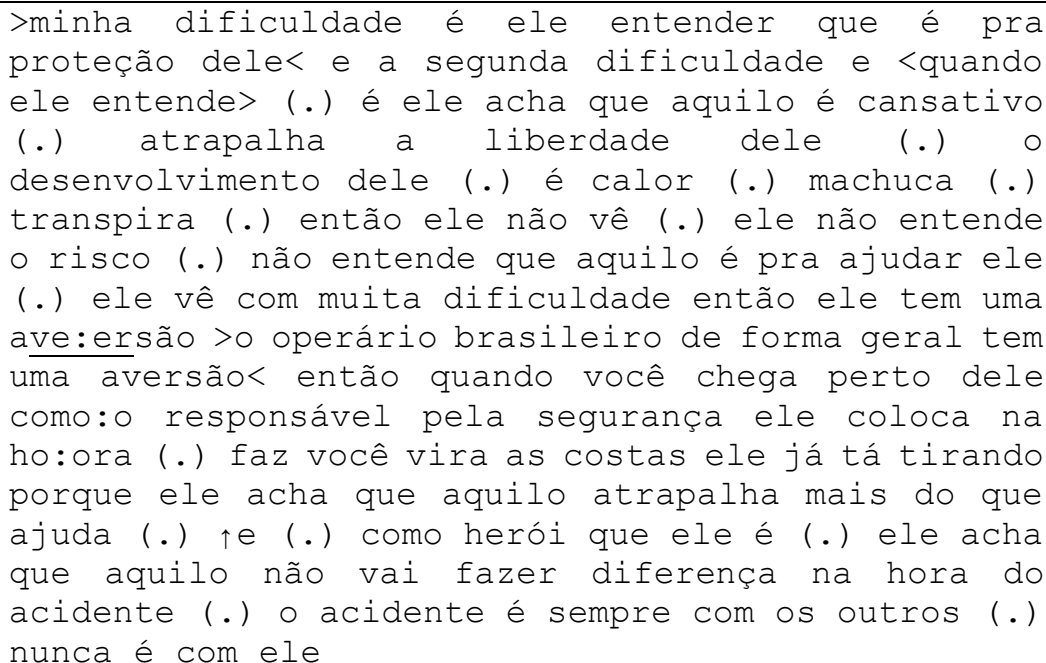 \\
\hline
\end{tabular}

A contribuição inicial de Felipe já aponta para o processo de desreponsabilização do gerente para os acidentes envolvendo a sua equipe (>minha dificuldade é ele entender que é pra proteção dele<-linhas 49 e 50). Se essa dificuldade aponta para o bloqueio cultural, a segunda dificuldade agrava a responsabilização porque envolve o conhecimento que o empregado já tem, mas ao mesmo tempo a impossibilidade de fazer uma avaliação do custo e benefício do uso do equipamento (ele não vê (.) ele não entende o risco (.) não entende que aquilo é pra ajudar ele (.) ele vê com muita dificuldade-linha 54 a 56). Além disso, Felipe evidencia o ato faltoso (item 1.8.1 da NR-1) do trabalhador ao negligenciar o uso do EPI. Deixar de usar o equipamento de proteção individual (EPI) salienta um ato inseguro, respaldada em um comportamento imprudente, em que o trabalhador deixa de observar as normas de segurança que consta na NR-1.

Essa visão do trabalhador que não coopera é levada ao extremo quando generalizada, nas linhas 57 e 58 (>o operário brasileiro de forma geral tem uma aversão<).

Felipe, ao utilizar a categoria operário brasileiro, resgata um conjunto de significados negativos atrelados a categoria classe operária brasileira.

Por meio de uma narrativa hipotética (quando você chega perto dele como: o responsável pela segurança ele coloca na ho:ora (.) faz você 
vira as costas ele já tá tirando- linha 58 a 60), o entrevistado categoriza o trabalhador como uma criança que só obedece as normas na frentes dos pais.

Outra categorização emerge na linha 62: a de herói, pois dadas as condições de vida, ele é um sobrevivente. Seria por essa crença uma pessoa que não precisaria de usar artefatos de segurança.

Nas linhas 62, 63 e 64 Felipe traz a categoria de "herói" (como herói que ele é (.) ele acha que aquilo não vai fazer diferença na hora do acidente). De acordo com essas categorias, o fato de o trabalhador sobrevier às suas condições de vida e sobreviver e de haver um culto à virilidade dispensaria o uso dos artefatos de segurança. Como consequência, o entrevistado atribui ao trabalhador uma certa sensação de onipotência, por ver-se invulnerável (o acidente é sempre com os outros (.) nunca é com ele-linhas 64 e 65).

Uma narrativa que não integra o corpus deste estudo merece ser incluída aqui, uma vez que confirma essa relação entre a categoria operário, machismo e onipotência.

\section{Excerto 5: todos os outros eram super-heróis}

\begin{tabular}{|c|c|c|}
\hline $\begin{array}{l}98 \\
99 \\
100 \\
101 \\
102 \\
103 \\
104 \\
105 \\
106 \\
107 \\
108 \\
109 \\
110 \\
111 \\
112 \\
113 \\
114 \\
115 \\
116 \\
117 \\
118 \\
119\end{array}$ & FELIPE: & $\begin{array}{l}\text { na época da refinaria (.) o pessoal desco- eles } \\
\text { começaram em } 92 \text { um processo novo (.) pro tratamento } \\
\text { da qualidade da gasolina (.) esse tratamento } \\
\text { começou a gerar uma série de doenças uma doença } \\
\text { chamada leucopenia uma espécie de (.) leucemia (.) } \\
\text { câncer no sangue (.) e aí tinha mais de cinquenta } \\
\text { quase cem pessoas afastadas no inss por conta disso } \\
\text { (.) a empresa preocupada (.) chamou especialistas } \\
\text { (.) começou a entender qual era o problema e } \\
\text { determinou que todo mundo deveria usar máscara de } \\
\text { respiraça ou filtros especiais por conta do risco } \\
\text { a inalação que tava gerando essa doença (.) na } \\
\text { primeira semana todo mundo uso:ou (.) na segunda } \\
\text { semana começou a para:ar (.) depois de um- depois } \\
\text { de seis meses só tinha um funcionário que usava (.) } \\
\text { ele ficou usando por um ano (.) e era o único virou } \\
\text { motivo de chacota na refinaria inteira (.) e ele } \\
\text { acabou pedindo demissão (.) porque ele entendia a } \\
\text { preocupação dele (.) a preocupação com a saúde dele } \\
\text { (.) ele não queria abrir mão mas ele não queria } \\
\text { trabalhar com a máscara (.) que todos os outros } \\
\text { eram super-heróis não precisavam daquilo só ele }\end{array}$ \\
\hline 120 & AMANDA: & Entendi \\
\hline $\begin{array}{l}121 \\
122 \\
123 \\
124\end{array}$ & FELIPE: & $\begin{array}{l}\text { ele não conseguiu VENCER a pressão do lado negativo } \\
\text { né? do lado errado (.) então ele acabou pedindo } \\
\text { demissão por causa disso (.) ou seja o único certo } \\
\text { (.) virou o errado }\end{array}$ \\
\hline
\end{tabular}


Apesar de pesquisas mostrarem que a imagem de super-herói ser uma grande fonte de angústia masculina (ALMEIDA, 2002a), observa-se que o uso do equipamento seria também entendido como um risco a essa imagem. Como Almeida (et al. 2005) concluem, homens que não sentem medo não são capazes de dosar o grau de risco da situação. No contexto empresarial, em terríveis acidentes (ALMEIDA, 2002b).

\section{2}

\section{A segunda peça do dominó}

Outro modo de responsabilizar o trabalhador é o de relacionar intencionalidade e conhecimento a acidentes no trabalho. Nesses casos, observa-se o agravamento da responsabilidade, como mostra o excerto 6 :

\section{Excerto 6: se o cara quer morrer ele vai dar um jeito de morrer}

\begin{tabular}{|c|c|c|}
\hline $\begin{array}{l}66 \\
67\end{array}$ & AMANDA: & $\begin{array}{l}\text { durante a sua trajetória profissional você já:á } \\
\text { presenciou ou já viu algum relato de acidente }\end{array}$ \\
\hline 68 & FELIPE: & . hh engraçado que eu nunca presenciei um acidente \\
\hline 69 & & fa- grave ${ }^{\circ}$ nunca ${ }^{\circ}$ já vi vários relatos de vários \\
\hline 70 & & $\downarrow$ aconteceram sob a minha gestão mas eu não estava \\
\hline 71 & & no momento (.) foi falta de gerenciar espalhado né? \\
\hline 72 & & é:é um acidente fatal que teve na obra da (nome da \\
\hline 73 & & empresa) (.) um acidente fatal que teve na obra da \\
\hline 74 & & (nome da empresa) (.) um acidente fatal na obra da \\
\hline 75 & & (nome da empresa) (.) mas eu sempre tava distante \\
\hline 76 & & (.) ouvia os relatos (.) e $\uparrow$ invariavelmente foram \\
\hline 77 & & não seguiram os \\
\hline 78 & & procedimentos (.) então não foi nada tipo assim (.) \\
\hline 79 & & ah a empresa não fazia segura: ança (.) o assunto \\
\hline 80 & & estava descuida:ado e acabou \\
\hline 81 & & invariavelmente porque $\circ$ cara não seguiu $\circ$ que \\
\hline 82 & & deveria fazer >às vezes coisas básicas< é:é e a \\
\hline 83 & & difi- eu tenho uma frase que eu uso sempre com os \\
\hline 84 & & alunos na faculdade (.) não existe sistema à prova \\
\hline 85 & & de bobo se o cara quer morrer ele vai dar um jeito \\
\hline 86 & & de morrer (.) vai fazer uma coisa que você não \\
\hline 87 & & conseguiu $\uparrow$ pensar o cara conseguiu arrumar um (.) \\
\hline 88 & & jeito de fazer uma coisa de um jeito que ninguém \\
\hline 89 & & esperava e acabou acontecendo aquele acidente e o \\
\hline 90 & & cara morreu (.) mas eu botei essa proteção (.) essa \\
\hline 91 & & barreira (.) essa sinalização (.) o cara não olhou \\
\hline 92 & & nada daquilo e fez ${ }^{\circ}$ então ${ }^{\circ}$ é complicado mesmo (.) \\
\hline 93 & & que o baixo nível cultural do nosso po:ovo (.) pela \\
\hline 94 & & falta de percepção de ri:isco (.) pela teimosia em \\
\hline 95 & & não seguir procedimento (.) tudo isso tá muito na \\
\hline 96 & & nossa cultura né? essa que é a dificuldade nossa \\
\hline
\end{tabular}


Felipe abre sua fala destacando o fato de nunca ter presenciado um acidente grave, o que pode implicar a sua competência para gerir pessoas que executam tarefas de alto risco. Mas logo em seguida fala de relatos de acidente e, através de uma formulação extrema (†invariavelmente foram porque os funcionários não seguiram os procedimentos - linha 76 a 78) responsabiliza os acidentados por terem conhecimento, mas não seguirem as normas de segurança. Observa-se, ainda, o processo de desresponsabilização da empresa (então não foi nada tipo assim (.) ah a empresa não fazia segura:ança (.) o assunto estava descuida:ado e acabou acontecendo - linha 78 a 80). Foi o ato inseguro do trabalhador que resultou no acidente.

Dessa crença, deriva uma das lições que dá aos seus alunos em curso de segurança do trabalho (não existe sistema à prova de bobo se o cara quer morrer ele vai dar um jeito de morrer-linha 84 a 86). O que pressupõe essa lição é o entendimento de que, quando o trabalhador quer, ele procura um jeito de se acidentar, uma crença da Teoria de Propensão ao Acidente, desenvolvida por Dwyer (1991). Um reflexo dessa crença pode ser apreciado em algumas campanhas de prevenção, realizadas por algumas empresas: "pense na sua família”, “coloque a vida sempre em primeiro lugar". Essa imagem de um "suicida em potencial" tem também a função de desresponsabilizar a empresa, como descreve Felipe, entre as linhas 86 e 92 (vai fazer uma coisa que você não conseguiu ipensar o cara conseguiu arrumar um (.) jeito de fazer uma coisa de um jeito que ninguém esperava e acabou acontecendo aquele acidente e o cara morreu (.) mas eu botei essa proteção (.) essa barreira (.) essa sinalização (.) o cara não olhou nada daquilo e fez). Por meio de um "eu" indeterminado, Felipe mostra que o trabalhador procurou o acidente. Num hibridismo teórico, o entrevistado volta à Teoria dos Dominós, mostrando que a impossibilidade de se evitar acidentes deve-se à cultura do trabalhador ( ${ }^{\circ}$ então ${ }^{\circ}$ é complicado mesmo (.) que o baixo nível cultural do nosso po:ovo linha 92 e 93), a resistência em abandonar a cultura de berço base (pela falta de percepção de ri:isco (.) pela teimosia em não seguir procedimentolinha 93 a 95).

Vemos, assim, o reforço das explicações invocadas pela teoria dos dominós. Heinrich, já na década de 30, afirmava que a tendência e o meio social são responsáveis por características como o descuido, a teimosia e outros traços 
indesejáveis de caráter que, na compreensão do autor, podem ser hereditários e/ou ser desenvolvido pelo meio social (pela teimosia em não seguir procedimento (.) tudo isso tá muito na nossa cultura né? - linha 94 a 96).

Alinhado a essa teoria, Robson traz exemplos de outros "traços indesejáveis de caráter" que propiciam atos inseguros. Quando perguntado se ele já presenciou alguém se recusando a executar algum tipo de trabalho devido ao risco, inicialmente, ele narra seus próprios cuidados em avaliar e evitar situações de risco, em seguida, discursa sobre os trabalhadores. Vejamos a narrativa que trata do ato inseguro do trabalhador, segundo o Robson.

\section{Excerto 7: ele vai no risco}

\begin{tabular}{|c|c|c|}
\hline $\begin{array}{l}85 \\
86 \\
87\end{array}$ & AMANDA: & $\begin{array}{l}\text { no decorrer da sua vida profissional (.) você já } \\
\text { presenciou alguém se recusando a algum tipo de } \\
\text { trabalho devido ao risco de acidente }\end{array}$ \\
\hline $\begin{array}{l}88 \\
89 \\
90 \\
91 \\
92 \\
93 \\
94 \\
95 \\
96 \\
97 \\
98 \\
99 \\
100 \\
101 \\
102 \\
103 \\
104 \\
105 \\
106 \\
107 \\
108 \\
109 \\
110 \\
111 \\
112 \\
113 \\
114 \\
115\end{array}$ & ROBSON : & 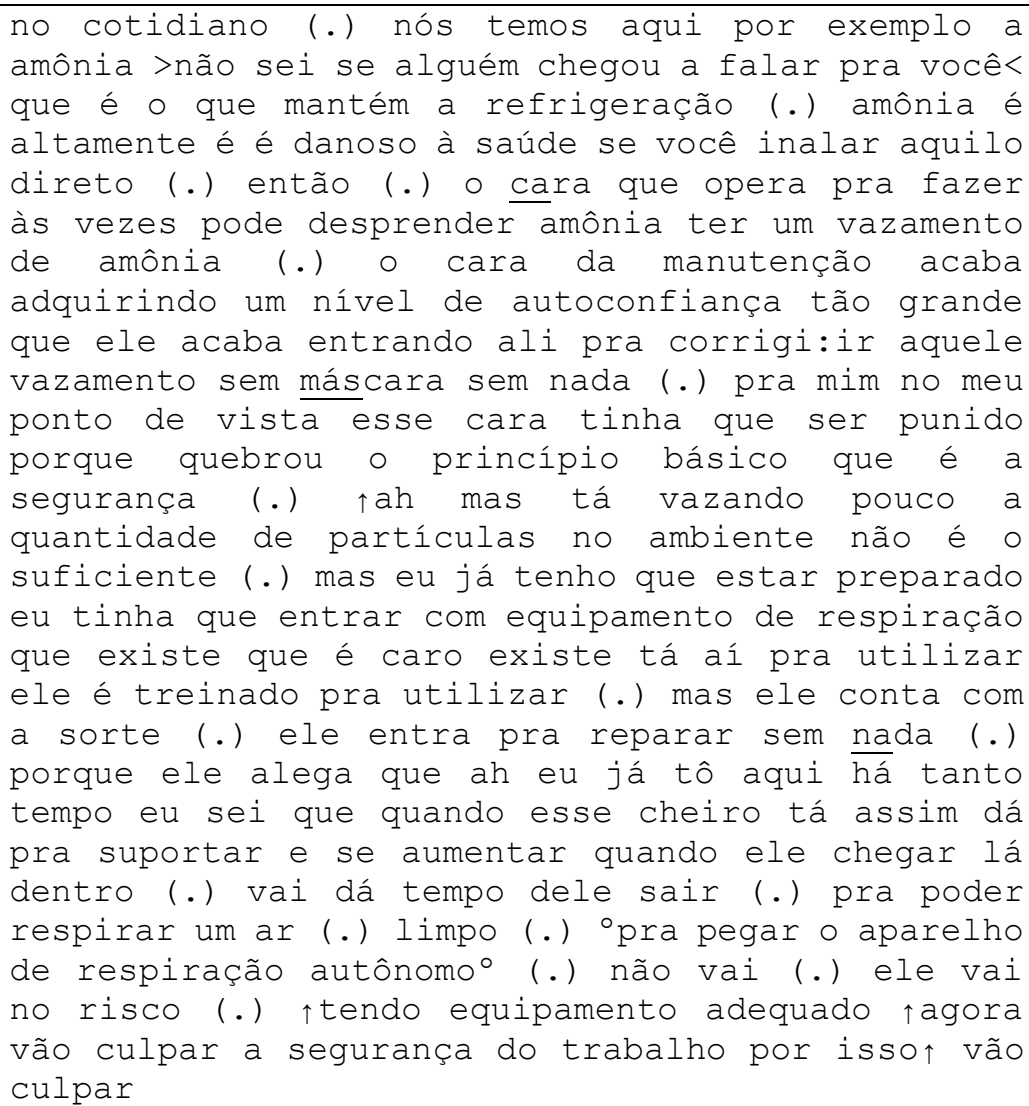 \\
\hline
\end{tabular}

$\mathrm{Na}$ abertura da fala, o entrevistado explica o risco de quem trabalha com amônia para logo em seguida produzir uma narrativa cujo ponto é justificar os acidentes por outro traço de caráter indesejado: a autoconfiança ( o cara da manutenção acaba adquirindo um nível de autoconfiança tão grande 
que ele acaba entrando ali pra corrigi:ir aquele vazamento sem máscara sem nada - linha 94 a 97). Simulando o raciocínio do trabalhador, ele reporta a fala interna dele ( $\uparrow$ ah mas tá vazando pouco a quantidade de partículas no ambiente não é o suficiente - linha 100 a 102). Ter conhecimento do risco, dispor de EPI para enfrentar aquela situação e não utilizar se confirma o que Amalberti (1996 apud BALLARDIM, 2007) já defenderam ainda que sem evidências: trabalhadores mais experientes tendem a cometer mais erros, embora tenham a habilidade mais apurada em detectá-los e corrigi-los (um vazamento de amônia (.) o cara da manutenção acaba adquirindo um nível de autoconfiança tão grande que ele acaba entrando ali pra corrigi:ir aquele vazamento sem máscara sem nada-linha 93 a 97). A conclusão é de que o trabalhador escolheu o risco (ele vai no risco - linhas 112 e 113).

A narrativa defende a tese de que o acidente é um evento esperado porque o indivíduo realizou um evento inesperado, isto é, não seguiu as normas, apesar do seu conhecimento. E num tom mais irônico, afirma que responsabilização pelo acidente vai ser deslocada injustamente ( $\uparrow$ agora vão culpar a segurança do trabalho por isso $\uparrow$ - linhas 113,114$)$.

Se, na fala dos entrevistados anteriores, percebe-se apenas a culpabilização do acidentado, na fala dos entrevistados seguintes ocorre um esforço de fugir dessa tendência mais geral.

Para entendermos melhor a dificuldade desses entrevistados em equilibrarem crenças do senso comum e outras menos consagradas, dividimos a análise do excerto 8 em três partes:

\section{Excerto 8 A: ele sabe o que ele tá fazendo}

\begin{tabular}{|c|c|c|}
\hline $\begin{array}{l}151 \\
152 \\
153\end{array}$ & AMANDA: & $\begin{array}{l}\text { ao seu ver qual é a responsabilidade do:o (.) } \\
\text { do acidentado (.) no acidente (.) }{ }^{\circ} \text { quando o } \\
\text { acidente ocorre }{ }^{\circ}\end{array}$ \\
\hline $\begin{array}{l}154 \\
155 \\
156 \\
157 \\
158 \\
159 \\
160 \\
161 \\
162 \\
163 \\
164\end{array}$ & JOÃO PEI & $\begin{array}{l}\text { assim é complicado a gente falar da } \\
\text { responsabilidade } \uparrow \text { deles (.) porque assim a } \\
\text { gente faz o possível pra conscientizar todo } \\
\text { mundo (.) oentendeu }{ }^{\circ} \text { tanto é que por exemplo } \\
\text { quando você entra na empresa você passa por } \\
\text { um treinamento de integração (.) então ali } \\
\text { iele já começa a ser imputado das ideias de } \\
\text { segurança da empresa (.) e nas unidades também } \\
\text { a gente faz uma série de treinamentos (.) não } \\
\text { só pra falar de acidente mas a gente fala de } \\
\text { ergonomi:ia fala da importância dos EPIs (.) }\end{array}$ \\
\hline
\end{tabular}




\begin{tabular}{|l|l|l|}
\hline 165 & noções de combate a incêndio (.) e por aí vai \\
166 & (.) então a gente dá uma sé:érie de \\
167 & treinamentos (.) pra que ele (.) não vou falar \\
168 & que se sinta totalmente habilitado (.) mas que \\
169 & ele tenha noções \\
\hline
\end{tabular}

A primeira parte da resposta de Joao Pedro envolve o trabalho moral de desresponsabilizar empresa e liderança pelos acidentes. Análoga a uma estrutura de lista, o entrevistado enumera as ações da empresa para o desenvolvimento de uma cultura de segurança. Em primeiro lugar, fala do trabalho de conscientização (a gente faz o possível pra conscientizar todo mundo - linha 155 a 157). Em seguida, do oferecimento de treinamento desde a entrada do trabalhador na empresa (quando você entra na empresa você passa por um treinamento

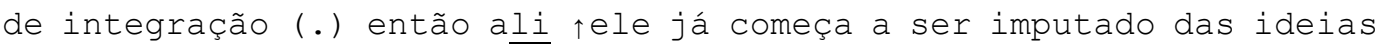
de segurança da empresa - linhas 158 a 161). Dessa abertura pode-se inferir que a responsabilidade pelos acidentes está mesmo nas mãos do trabalhador, pois ele tem o conhecimento ou, em suas palavras, as noções básicas da importância da segurança.

Em seguida, João Pedro busca um modo de distribuir a responsabilidade entre empregado e liderança:

\section{Excerto 8 B: geralmente é um descuido}

\begin{tabular}{|c|c|c|}
\hline $\begin{array}{l}171 \\
172 \\
173 \\
174 \\
175 \\
176 \\
177 \\
178 \\
179 \\
180 \\
181 \\
182 \\
183\end{array}$ & JOÃO PEDRO: & $\begin{array}{l}\text { entendeu então eu acho que (.) quando acontece } \\
\text { geralmente (.) pode >igeralmente é um } \\
\text { descuido< mas assim (.) } \uparrow \text { ele sabe o que ele } \\
\text { tá fazendo (.) geralmente é isso mas eu nunca } \\
\text { posso falar que a responsabilidade é cem por } \\
\text { cento dele (.) nunca faço isso e não aceito } \\
\text { isso também (.) porque eu me cobro muito } \\
\text { também então eu acho que (.) é minha } \\
\text { responsabilida:ade (.) treinar mas também é } \\
\text { minha responsabilidade saber se meu } \\
\text { treinamento foi eficaz (.) então sempre que } \\
\text { acontece um acidente é uma oportunidade da } \\
\text { gente reciclar o treinamento }\end{array}$ \\
\hline 184 & AMANDA: & entendi \\
\hline $\begin{array}{l}185 \\
186 \\
187 \\
188\end{array}$ & JOÃO PEDRO: & $\begin{array}{l}\text { e aí a gente não pega só o colaborador a gente } \\
\text { pega todo mundo da unidade (.) } \text { então } \\
\text { geralmente é assim que eu faço } \uparrow \text { mas nunca cem } \\
\text { por cento isso nunca (.) nunca }\end{array}$ \\
\hline
\end{tabular}

$\mathrm{Na}$ segunda parte da resposta, João Pedro inicia o processo de responsabilização do trabalhador, ainda que modalizado pelo uso do advérbio (geralmente) e apresentando como ato inseguro algo que pode acontecer a 
qualquer um (>†geralmente é um descuido<-linhas 172 e 173). Ao normalizar o risco (descuido), o entrevistado enfraquece a atribuição da culpa, mas logo em seguida a agrava quando informa que o empregado tinha o conhecimento de como se proteger (mas assim (.) tele sabe o que ele tá fazendo-linhas 173 e 174).

Observa-se ainda nessa segunda parte um afastamento de uma posição que endossa a Teoria do Dominó. Ao tratar o descuido como a causa do acidente, ele entende que a variação ou desvio do processo está baseada no indivíduo, um dos componentes utilizados em análise de acidentes pelo Método da Árvore de Causas. Nessa linha, inclui como causa o fato de nem sempre haver uma avalição da eficácia dos programas de conscientização da segurança (porque eu me cobro muito também então eu acho que (.) é minha responsabilida:ade (.) treinar mas também é minha responsabilidade saber se meu treinamento foi eficaz - linha 177 a 181).

O empenho em distribuir responsabilidades leva o entrevistado a marcar sua posição usando por duas vezes o recurso da formulação extrema (eu nunca posso falar que a responsabilidade é cem por cento dele (.) nunca-linha 174 a 176) e (isso nunca (. ) nunca - linha 188). Dado que as explicações não são destituídas de valores morais, o modo como o entrevistado repudia a culpabilização única do empregado e chama para si também a responsabilidade por um acidente (porque eu me cobro muito - linha 177), há aqui um trabalho de gerenciamento de impressões positivas sobre si mesmo e a introdução de uma norma cultural mais alinhada com a humanização do trabalhador e do trabalho.

\section{Excerto 8 C: ele pode estar com algum problema}

\begin{tabular}{|l|l|l|}
\hline 189 & AMANDA: & uhum \\
\hline 190 & JOÃO PEDRO: & acontece às vezes ele pode estar com algum \\
191 & & proble:ema pfatores externos influenciam no \\
192 & & seu dia a dia de trabalho isso é natural $\uparrow$ eu \\
193 & & vejo como natural (.) aquela coisa assim ah é \\
194 & & da rua deixa na rua não traz pro trabalho (.) \\
195 & & ou é do trabalho não leva pra casa é \\
196 & & impossivel (.) impossível (.) então eu vejo \\
197 & & acidente como uma oportunidade de eu melhorar \\
198 & & ainda mais o meu processo \\
\hline
\end{tabular}

Na terceira parte da resposta, outra explicação é introduzida: os problemas pessoais (às vezes ele pode estar com algum proble:ema-linhas 190 e 
191). Mais uma vez, o entrevistado humaniza esse trabalhador, naturalizando a causa (isso é natural peu vejo como natural-linhas 192 e 193). Aqui a teoria invocada é a do Queijo Suíço. Defende-se aí que fatores externos formariam buracos na camada de proteção. A falha humana (REASON, 2000), portanto, provocada por um problema externo geraria "o buraco", produzindo o acidente.

Uma outra entrevistada tenta se afastar da crença de senso comum que o acidentado é o responsável pelo acidente:

\section{Excerto 9: vejo como falta de conhecimento distração}

\begin{tabular}{|c|c|c|}
\hline $\begin{array}{l}75 \\
76\end{array}$ & AMANDA : & $\begin{array}{l}\text { ao seu ver qual é a responsabilidade do acidentado } \\
\text { (.) no acidente }\end{array}$ \\
\hline $\begin{array}{l}77 \\
78 \\
79 \\
80 \\
81 \\
82 \\
83 \\
84 \\
85 \\
86 \\
87 \\
88 \\
89 \\
90 \\
91 \\
92 \\
93 \\
94 \\
95 \\
96\end{array}$ & RITA: & $\begin{array}{l}\text { então (.) eu acho errado falar (.) porque eles usavam } \\
\text { muito ah culpa foi dele (.) eu acho que no acidente } \\
\text { não tem culpados tem os motivos (.) os causadores } \\
\text { (.) mas eu não vejo como um culpado pode ser (.) ele } \\
\text { pode (.) ele tem interferência no acidente? tem (.) } \\
\text { tem uma pesquisa da Dupont antiga que se eu não me } \\
\text { engano } 94 \text { o dos acidentes acontecem por falha humana } \\
\text { 6\% por intempé:éries ou } 94 \text { ou } 96 \text { (.) mas de fato } \\
\text { acontecem por pessoas mas podem se:er (.) por exemplo } \\
\text { eu vou aqui (.) no armazém (.) eu vou tirar uma caixa } \\
\text { vou deixar no meio do caminho (.) não é rapidinho } \\
\text { daqui a pouco eu volto aí vem outro que não sabe que } \\
\text { a caixa tá no meio do caminho pode tropeçar cair e } \\
\text { causar um acidente grave< (.) entã ão (.) mas não } \\
\text { vejo como culpa eu vejo como falta de conhecimento } \\
\text { distração as pessoas são muito distraídas e aí eu } \\
\text { acho que falta nas pessoas em geral aquele estado de } \\
\text { alerta sabe? de por exemplo eu vou chegar no luga:ar } \\
\text { (.) eu vou identificar o risco do loca:al (.) por } \\
\text { exemplo pegou fogo aqui por onde você saiu }\end{array}$ \\
\hline
\end{tabular}

Rita, como João Pedro, deseja se afastar da crença perversa de culpabilização unicamente do empregado (eu acho errado falar (.) porque eles usavam muito ah culpa foi dele (.) eu acho que no acidente não tem culpados tem os motivos (.) os causadores - linha 77 a 79).

Mas, como João Pedro, observa-se que ela acaba por apontar para o comportamento do empregado como o que denominou um motivo. $\mathrm{O}$ discurso de Rita é equilibrar as diferentes crenças sobre acidentes. Logo após optar por uma diferenciação entre culpa (algo marcadamente moral) e motivo (não marcado), Rita traz o resultado de uma pesquisa que supostamente traria evidência de que o empregado é o responsável principal (tem uma pesquisa da Dupont antiga que se eu não me engano 94\% dos acidentes acontecem por falha humana - 
linhas 82 e 83). O que é defendido também por Reason (1990) que indica que entre 50 e $80 \%$ dos acidentes são decorrentes do indivíduo.

Mas, logo em seguida, busca minimizar o peso dessa estatística, introduzindo duas explicações: o conhecimento e a distração.

A primeira explicação como já vimos, pode ser um mitigador da responsabilidade. Eles causam acidentes por falta de conhecimento suficiente. A segunda explicação naturaliza o comportamento inseguro, uma vez que qualquer ser humano pode se distrair (não vejo como culpa eu vejo como falta de conhecimento distração - linha 90 a 92).

Numa tentativa de atenuar a responsabilidade do acidentado, Rita, como João Pedro, inclui alguns comportamentos inadequados na categoria comportamentos humanos. Todas as pessoas têm dificuldade de separar problemas pessoais ao entrar no trabalho; todas as pessoas podem ter distrações ou, como afirma a teoria, ter um traço de caráter não desejado (a distração).

Este capítulo mostrou, portanto, a força de teorias antigas que ainda alimentam os conhecimentos de senso comum sobre acidentes de trabalho. Mostrou também a dificuldade de distribuir responsabilidade e atribuir pesos diferenciados de responsabilidade. Se por um lado, agência, conhecimento, intencionalidade e racionalidade são evidenciados como agravantes da responsabilidade, por outro lado isso ainda é dirigido com mais frequência ao empregado.

Outro ponto que merece destaque é o modo como os entrevistados tendem mais a buscar culpados do que considerar a responsabilidade de todos para uma política de segurança no trabalho. 


\section{6}

\section{A Empresa como Responsável}

Visto o capítulo anterior que buscou evidenciar as explicações para os acidentes focadas nas concepções de senso comum de ato inseguro, trataremos, neste capítulo, das explicações que implicam a desconstrução desse paradigma tradicional de segurança. $\mathrm{O}$ foco agora é o modo como os entrevistados atribuem responsabilidade às empresas pela ocorrência de acidentes de trabalho. Na seção 6.1, tratamos das explicações que apontam para desvalorização da segurança na cultura empresarial. Na seção 6.2, focalizamos aspectos da cultura empresarial tidos pelos entrevistados como obstáculos ao desenvolvimento da segurança. Na seção 6.3, apresentamos as explicações fundadas no que se conhece como a política de acidente zero.

\section{1 \\ O valor da segurança na cultura empresarial}

Como vimos no capítulo anterior, os entrevistados atribuíram uma parte da responsabilidade pela falta de uma cultura de segurança ao fato de os trabalhadores pertencerem a culturas em que a segurança não é um valor. Nesta seção, observamos como a cultura empresarial também é vista como a vilã.

As explicações foram agrupadas em três subseções: o espaço físico da área de segurança e saúde, a invisibilidade dos profissionais dessas áreas, e a inconsistência entre o discurso da segurança e a prática.

\subsection{1 \\ O espaço físico}

O primeiro meio de explicar a desvalorização da segurança pela empresa é o lugar físico que é destinado à área da saúde e segurança. Foi perguntado ao Robson, como ele imagina que o risco é compreendido pelos diferentes níveis, trabalhadores e a alta direção. Inicialmente, Robson comenta sobre o excesso de confiança dos trabalhadores que não permite que eles compreendam o risco. Em seguida, ressaltou o quanto a saúde e segurança do trabalho não é valorizada pelas 
empresas, que são raríssimas as que envolvem a saúde e segurança numa licitação, e acrescenta a falta de espaço físico para o profissional de saúde e segurança em algumas empresas.

\section{Excerto 10 A: na salinha que sobrou}

\begin{tabular}{|c|c|c|}
\hline $\begin{array}{l}46 \\
47 \\
48 \\
49 \\
50 \\
51\end{array}$ & ROBSON : & $\begin{array}{l}\text { a saúde e a segurança (.) } \uparrow \text { se você olhar (.) } \\
\text { qualquer empresa que você for (.) >até que tem } \\
\text { mudado um pouco< mas } \uparrow \text { sala da segurança do } \\
\text { trabalho é sempre:e } \uparrow \text { ou na salinha que sobrou no } \\
\text { fina:al ou então >embaixo da escada< aquele } \\
\text { vãozinho embaixo da escada? (.) bota ali }\end{array}$ \\
\hline $\begin{array}{l}52 \\
53\end{array}$ & AMANDA: & $\begin{array}{l}\text { †colocaram aquela parede lá que é diferente que } \\
\text { é:é [que não é parede mesmo] }\end{array}$ \\
\hline 54 & ROBSON : & {$[\downarrow d r y w a l l]$} \\
\hline 55 & AMANDA: & $\uparrow$ isso \\
\hline $\begin{array}{l}56 \\
57 \\
58 \\
59 \\
60 \\
61 \\
62 \\
63 \\
64 \\
65 \\
66\end{array}$ & ROBSON: & 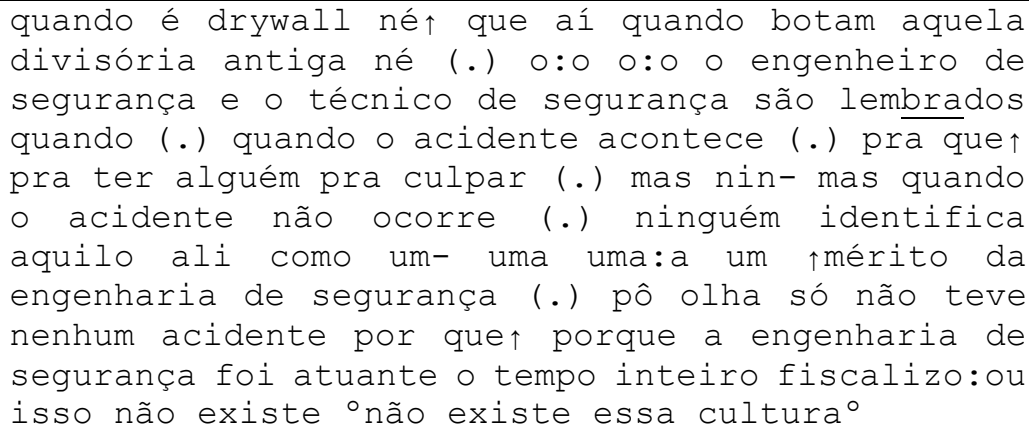 \\
\hline
\end{tabular}

Apesar de reconhecer que está havendo mudanças, o entrevistado usa uma formulação extrema ( $\uparrow$ sala da segurança do trabalho é sempre:e-linhas 48 e 49) para caracteriza o lugar como um espaço não planejado nem privilegiado. Para tanto, caracteriza o lugar pela dimensão e pela condição de "resto" (na salinha que sobrou - linha 49). A depreciação continua quando Robson situa onde fica a sala (embaixo da escada< aquele vãozinho embaixo da escada? (.) bota ali-linhas 50 e 51).

Em seguida, respondendo a uma dúvida da entrevistadora sobre o tipo de parede, acrescenta outra evidência da precariedade do espaço: o tipo de parede (é drywall né - linha 56) e o tipo de divisória (botam aquela divisória antiga - linhas 56 e 57).

Fecha ainda o turno introduzindo um outro argumento que evidencia a desvalorização da cultura: a invisibilidade dos participantes. 


\section{1 .2}

\section{A invisibilidade dos profissionais}

Como mostra a fala de Robson, a empresa não reconhece o trabalho dos profissionais da área (por que $\uparrow$ porque a engenharia de segurança foi atuante o tempo inteiro fiscalizo:ou isso não existe ${ }^{\circ}$ não existe essa cultura ${ }^{\circ}$ - linha 64 a 66).

Agrava a acusação o fato de Robson restringir o reconhecimento da área aos momentos de ocorrência de acidentes, o que implicaria a responsabilização dessa área pelos acidentes.

Em um outro excerto, a questão da invisibilidade é retomada:

\section{Excerto 10 B: saúde e segurança é um anonimato}

\begin{tabular}{|l|l|l|}
\hline 68 & ROBSON: & entendeu $\uparrow$ então é um (.) saúde e segurança é um \\
69 & & anonimato (.) você tá envolvido com tudo mas você \\
70 & & nunca aparece (.) e quando aparece (.) apareceu pra \\
71 & & ser culpado na história \\
\hline
\end{tabular}

Para ele, não existe lugar de prestígio para esses profissionais na cultura da empresa. Além de nomear explicitamente a invisibilidade desses profissionais (é um anonimato - linhas 68 e 69) (nunca aparece - linha70), Robson reafirma a identidade dos profissionais da área como bode expiatório (o engenheiro de segurança e o técnico de segurança são lembrados quando (.) quando - acidente acontece (.) pra que pra ter alguém pra culpar-linha 57 a 60).

Outro aspecto levantado para evidenciar a responsabilidade das empresas por não valorizar a área da segurança pode ser considerado no excerto a seguir:

\section{Excerto 11: saúde e segurança não participa}

\begin{tabular}{|c|c|c|}
\hline $\begin{array}{l}78 \\
79 \\
80 \\
81 \\
82 \\
83 \\
84 \\
85 \\
86 \\
87 \\
88 \\
89 \\
90\end{array}$ & ROBSON : & $\begin{array}{l}\text { O cara (.) quando vai fazer uma licitação de uma } \\
\text { obra ele não pergunta a você (.) engenheiro de } \\
\text { segurança (.) ao serviço de engenharia segurança e } \\
\text { saúde ocupacional assim (.) o projeto é essa aqui } \\
\text { investi em dois mil homens trabalhando (.) a } \\
\text { operação vai ser em construção de gasoduto (.) o } \\
\text { risco é esse e aí (.) eu faço a minha projeção de } \\
\text { custo pra saúde e segurança (.) raríssimas são as } \\
\text { licitações que saúde e segurança participa (.) } \\
\text { então eles não colocam você (.) não participa (.) } \\
\text { saúde e segurança não participa (.) aí você vai lá } \\
\text { fazer uma previsão de sei lá cem milhões de reais } \\
\text { (.) numa obra (.) dagui a pouco guando esbarra na }\end{array}$ \\
\hline
\end{tabular}




\begin{tabular}{|l|l|l|}
\hline 91 & saúde e segurança começa a pedir epi epc exame \\
92 & perió:ódico isso aquilo aquilo outro (.) onera o \\
93 & cara (.) coisa que ele não previu \\
\hline
\end{tabular}

O primeiro ponto destacado é ausência dos profissionais da área no planejamento de uma obra (raríssimas são as licitações que saúde e segurança participa - linha 85 e 86). O segundo ponto é a falta de previsão de custos referentes à saúde e segurança (daqui a pouco quando esbarra na saúde e segurança começa a pedir epi epc exame perió:ódico isso aquilo aquilo outro (.) onera o cara (.) coisa que ele não previu-linha 90 a 93).

Entendemos que o fato de Robson ser um enfermeiro do trabalho explica porque só ele tornou relevante a questão da desvalorização da área e da invisibilidade de seus profissionais. Mas isso nos permitiu ver como a literatura não destaca questões como as examinadas.

\subsection{3}

\section{A inconsistência entre discurso e prática de segurança}

Um outro modo de evidenciar como a segurança não é um valor para as empresas se refere ao descompasso entre discurso e pratica.

\section{Excerto 12: $95 \%$ não pratica o que tá ali no papel}

\begin{tabular}{|c|c|c|}
\hline $\begin{array}{l}119 \\
120 \\
121 \\
122 \\
123 \\
124 \\
125 \\
126 \\
127\end{array}$ & ROBSON: & $\begin{array}{l}\text { praticar hoje em dia só tem programa de prevenção } \\
\text { no papel se você pegar um PPRA qualquer um de uma } \\
\text { empresa você vai ver } 200 \text { planejamento programa de } \\
\text { proteção respiratória programa de proteção } \\
\text { auditiva né programa ergômetro tá lá no papel } \\
\text { pratica não vou dizer } 90100 \% \text { não pratica 95\% não } \\
\text { pratica o que tá ali no papel praticar as } \\
\text { recomendações do documento PPRA é fundamental pra } \\
\text { poder senão não vai rolar }\end{array}$ \\
\hline 128 & AMANDA: & entendi \\
\hline $\begin{array}{l}129 \\
130 \\
131 \\
132 \\
133 \\
134 \\
135 \\
136\end{array}$ & ROBSON & $\begin{array}{l}\text { se pegar algum engenheiro de segurança de alguma } \\
\text { empresa pouquíssimas empresas vão dizer que } \\
\text { praticam aquilo que tá ali no papel não praticam } \\
\text { acho que a partir do momento que começar a } \\
\text { praticar aquilo ali a qualidade de vida melhora } \\
\text { muito de acidente bastante tem empresa que ela quer } \\
\text { investir em segurança (.) mas ela quer investir } \\
\text { (.) na teoria da segurança (.) né }\end{array}$ \\
\hline
\end{tabular}

Na primeira parte da sua fala, Robson chama a atenção para o contraste entre o número de programas para a área e a estatística relativa à implantação desses 
programas (95\% não pratica o que tá ali no papel-linhas 124 e 125). O agravamento da atribuição de responsabilidade à empresa pelo fato de terem conhecimento dos benefícios desses programas e não tirarem os projetos do papel.

Encerra sua fala, afirmando a natureza " fake" da cultura da segurança. Para Robson, trata-se apenas de discurso (tem empresa que ela quer investir em segurança (.) mas ela quer investir (.) na teoria da segurança (.) né - linha 134 a 136).

Rita, quando perguntada sobre a política de segurança da empresa, corrobora com o mesmo posicionamento, ao afirmar que a política de segurança existe apenas para cumprir tabela de empresa certificadora:

\section{Excerto 13: pra cumprir papel}

\begin{tabular}{|l|l|l|l|}
\hline 27 & RITA: & $\begin{array}{l}\text { você faz uma política hoje pra cumprir um papel (.) } \\
28\end{array}$ & $\begin{array}{l}\text { de repente (.) de uma sindicância de sistema de } \\
29\end{array}$ \\
30 & gestão integrada ou então da ohsas (.) mas de fato \\
31 & as pessoas não sentem aquilo (.) não internalizam \\
aquilo sabe
\end{tabular}

Rita cria uma distinção entre o que se diz e o que se sente; o que emerge na superfície e o que está fora; e o que está por baixo daquilo que está dentro; entre o que é crença e o que é aparência de crença (mas de fato as pessoas não sentem aquilo (.) não internalizam aquilo sabe - linha 29 a 31)

Outro entrevistado, Felipe, endossa, sem generalizar, esse discurso:

\section{Excerto 14: só no papel só pra poder inglês ver}

\begin{tabular}{|c|c|c|}
\hline $\begin{array}{l}11 \\
12 \\
13 \\
14 \\
15 \\
16\end{array}$ & AMANDA & $\begin{array}{l}\text { falando sobre segurança (.) >baseado na sua } \\
\text { experiência de vida< como você vê a política de } \\
\text { segura:ança <por onde você já passo:ou> pelas } \\
\text { empresas assim de forma geral } \uparrow \text { você acredita que } \\
\text { essa segurança chega até o funcionário chega até } \\
\text { aquele }\end{array}$ \\
\hline $\begin{array}{l}17 \\
18 \\
19 \\
20 \\
21 \\
22 \\
23 \\
24\end{array}$ & FELIPE & $\begin{array}{l}\text { hh o papel stricto sim (.) a política sim (.) e as } \\
\text { palavras sim (.) mas a mudança de postura (.) a } \\
\text { filosofia (.) ações (.) não chegam então fica muito } \\
\text { no discurso lá em cima e pouco na prática lá embaixo } \\
\text { (.) <isso muda muito de empresa pra empresa> >eu } \\
\text { trabalhei em empresas muito preocupadas muito } \\
\text { conscientes< (.) e empresas totalmente só:ó no } \\
\text { papel só:ó pra poder inglês ver }\end{array}$ \\
\hline
\end{tabular}

O abismo entre discurso e prática é agora representado na fala de Felipe pela distância entre a direção e o chão de fábrica. Falta integração. A imagem agora não 
se apoia na oposição dentro e fora, mas na de alto e baixo (então fica muito no discurso lá em cima e pouco na prática lá embaixo-linhas 19 e 20).

\section{2}

\section{A cultura da competitividade}

Em um mercado cada vez mais competitivo, a regra é produzir mais e gastar menos. Nesse contexto, a segurança, de acordo com nossos entrevistados, é colocada em segundo plano. O foco do excerto 15 é a questão da produtividade em detrimento da segurança:

\section{Excerto 15: sempre vai valer primeiro a entrega}

\begin{tabular}{|c|c|c|}
\hline $\begin{array}{l}26 \\
27 \\
28 \\
29 \\
30 \\
31 \\
32 \\
33 \\
34 \\
35 \\
36 \\
37 \\
38 \\
39 \\
40\end{array}$ & FELIPE: & $\begin{array}{l}\text { o pessoal da- da:a direção nível gerencial } \\
\text { coordenação os chefes eles entendem que a grande } \\
\text { preocupaça deles é com a produça eles têm que } \\
\text { entregar aquilo no prazo (.) na meta (.) na } \\
\text { urgência (.) então e- esse conflito entre prazo e } \\
\text { fazer com segura:ança e fazer com qualida:ade pra } \\
\text { ele é muito } \text { forte (.) então sempre vai valer } \\
\text { primeiro o- a entrega onde ele vai ser } \\
\text { questiona:ado onde ele vai ser avaliado >então se } \\
\text { ele tiver que abrir mão da segurança pra entregar } \\
\text { no prazo ele vai fazer< então ele não- por mais } \\
\text { que ele tenha capacidade de perceber o risco ele } \\
\text { acha que esse risco é } \text { perenciável por conta do } \\
\text { prazo de entrega aí ele faz isso e acaba } \\
\text { negligenciando orisco }\end{array}$ \\
\hline
\end{tabular}

De acordo com o entrevistado, a organização está dividida entre os que estão em posição de liderança (direção, nível gerencial, coordenação e os chefes) os que se orientam primordialmente a produtividade, e aqueles que estão sob essas lideranças que vivenciariam um falso dilema: o de respeitar prazos ou fazer o trabalho com segurança e qualidade. Trata-se de um falso dilema porque o trabalhador não se percebe tendo liberdade para escolher (sempre vai valer primeiro o- a entrega - linhas 32 e 33), dado o tipo de relação social estabelecida com as lideranças: o autoritarismo.

Segundo a Teoria da Produção Social do Erro, formulada por Dwyer (2000), os acidentes de trabalho são produzidos de acordo com o modo como é gerenciável o relacionamento entre o operário e seu trabalho. Logo muitos acidentes ocorrem porque os trabalhadores têm medo de punição (onde ele vai ser questiona: ado onde ele vai ser avaliado-linhas 33 e 34). A responsabilidade da empresa, 
então, é grande porque o empregado tem a percepção do risco (por mais que ele tenha capacidade de perceber o risco - linhas 36 e 37), mas faz o que a empresa prioriza (por conta do prazo de entrega aí ele faz isso e acaba negligenciando o risco - linha 38 a 40).

A explicação invocada para responsabilizar a empresa é ratificada pela literatura. Segundo Perrow (1999), produção é um dos fatores principais para a ocorrência de acidentes. Também há casos em que a pressão pela produção é tão forte, que se negar a realizar alguma atividade por falta de equipamento devido passa a ser algo negativo. O exemplo a ser seguido passa a ser daquele que não parou a produção, independentemente do uso completo do equipamento de segurança.

A questão da produtividade está de alguma forma relacionada ao modo como as empresas tratam o direito à recusa. Segundo Almeida \& Filho (2007) muitas vezes, nessas situações, de pressão, os operadores precisam fazer escolhas entre, de um lado, ações que visam a produção, porém contrariam normas de segurança, e, de outro, ações que privilegiam a segurança e implicam em atraso na retomada dos trabalhos. Acrescentamos que, além do atraso, possui o fator de ser interpretado negativamente pela conduta correta à segurança.

Por mais que na NR-10, no item 10.14.1, conste que os trabalhadores devem interromper suas tarefas exercendo o direito de recusa, sempre que constatarem evidências de riscos graves e iminentes para sua segurança e saúde ou a de outras pessoas, dada tanta pressão por produção, não são todos os operários que se sentem seguros em solicitar este direito, diante o medo de perder o emprego, ficar taxado como aquele que cria problemas ou que possui má vontade. Vejamos o excerto abaixo que trata sobre a questão do direito de recusa:

\section{Excerto 16: (a avaliação) passa a ser que eu parei a produção}

\begin{tabular}{|l|l|l|}
\hline 139 & AMANDA & $\begin{array}{l}\text { quando você Ppor exemplo< quando você:ê negou a:a } \\
\text { executar um serviço (.) quando você tava } \\
\text { >trabalhando lá na samu< é:é quando você disse que } \\
141\end{array}$ \\
142 & não ia fazer teve algu:m (.) alguma reação \\
\hline 143 & ROBSON: & sim \\
\hline 144 & AMANDA: & {$[$ em relação a isso] } \\
\hline 145 & ROBSON: & {$[$ sim] } \\
\hline 146 & AMANDA: & foi positiva ou não \\
\hline 147 & ROBSON: & não negativa sempre ((risos)) \\
\hline 148 & AMANDA: & ah (risos)) \\
\hline
\end{tabular}




\begin{tabular}{|c|c|c|}
\hline $\begin{array}{l}149 \\
150 \\
151 \\
152 \\
153 \\
154 \\
155 \\
156 \\
157 \\
158 \\
159 \\
160 \\
161 \\
162 \\
163 \\
164 \\
165 \\
166 \\
167 \\
168 \\
169 \\
170\end{array}$ & ROBSON : & 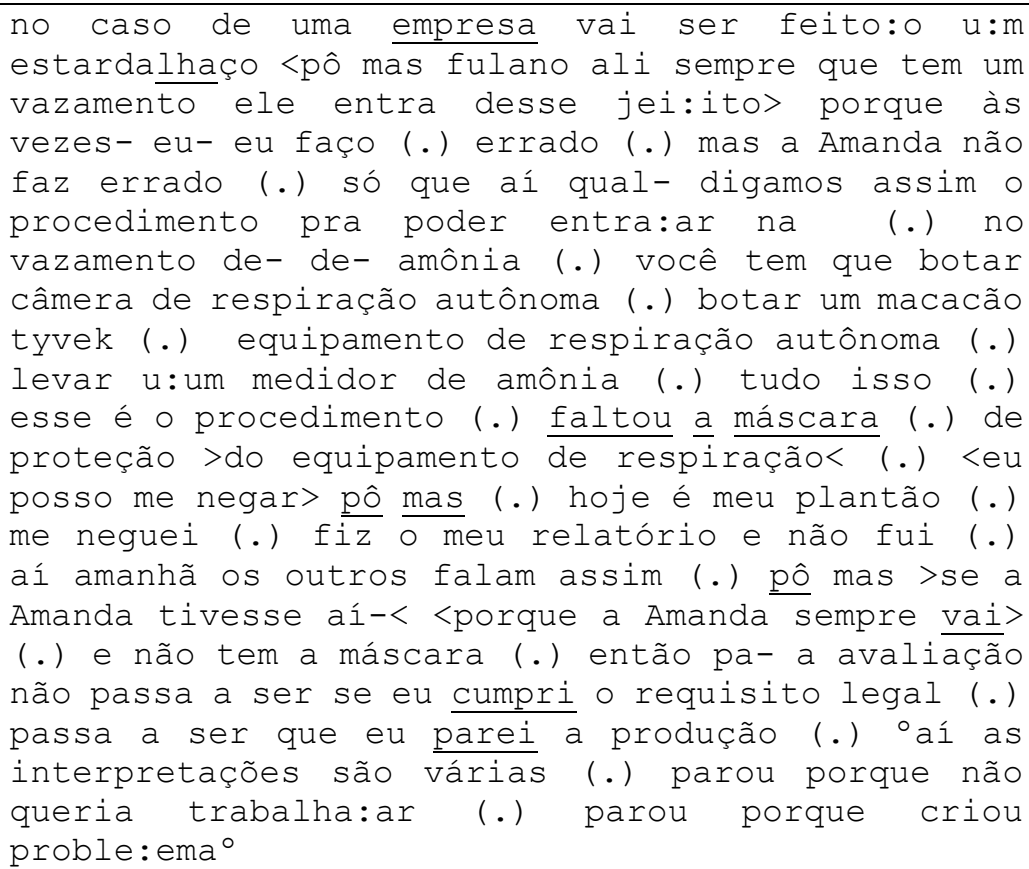 \\
\hline
\end{tabular}

Robson, por meio de uma narrativa fictícia, ilustra a pressão que os profissionais sofrem ao não terem o direito de priorizar a segurança. Utilizando um discurso reportado, ele aponta que operários a empresa quer (<pô mas fulano ali sempre que tem um vazamento ele entra desse jei:ito> porque às vezes- eu- eu faço (. ) errado - linha 150 a 152) A inversão de valores leva a valorização não da segurança mas da continuidade da produção ( $\underline{\text { pô }}$ mas >se a Amanda tivesse aí-< <porque a Amanda sempre vai> (.) e não tem a máscara - linha 163 a 165).

O entrevistado reitera a acusação de que a empresa estimula ou faz vista grossa desses fatos (a avaliação não passa a ser se eu cumpri 0 requisito legal (.) passa a ser que eu parei a produção-linha 165 a 167). O exercício do direito à recusa passa a ser interpretado como uma prática de preguiçosos ou pessoas problemáticas.

\section{3}

\section{A política do acidente zero}

A participação em lucros (PL) surgiu no Brasil como parte da estratégia governamental de estabilização econômica. O desafio de controlar a inflação implicava encontrar uma forma estável de exploração do trabalho (mais-valia) (PINA \& STOTZ, 2010). A PL introduziu na relação salarial uma modalidade de remuneração variável e condicionada a resultados, a metas. Contudo, na busca de 
se alcançar a meta, aumenta-se a carga de trabalho. Vista dessa maneira, a PL pode ser caracterizada como uma forma de administração por estresse que eleva e potencializa as cargas de trabalho e o desgaste do operário.

Embora a prática de atrelar benefícios ao não acidente não seja uma associação saudável, algumas empresas insistem em condutas semelhantes como incentivos. Há estudos que reforçam a teoria de que as chances de ocorrência de acidente aumentam quando o trabalhador realiza suas atividades, sem observar a segurança, na pressão por alcance de metas atreladas a benefícios monetários.

A questão colocada é que, em função da política de acidente zero, muitas práticas acabam por favorecer acidentes. Abaixo apresentamos algumas delas.

\subsection{1}

\section{A não comunicação do acidente}

As explicações para acidentes sustentadas pelas relações empresa x operário retiram não somente a responsabilidade dos gerentes e líderes de equipe, mas também culpabilizam a empresa por práticas que favorecem a ocorrência de acidentes. Uma delas é relacionar a participação no lucro à meta do acidente zero:

\section{Excerto 17 A: todo mundo omite}

\begin{tabular}{|c|c|c|}
\hline $\begin{array}{l}84 \\
85 \\
86\end{array}$ & AMANDA: & $\begin{array}{l}\text { essa relação com o médico:o da:a que- que libera } \\
\text { o trabalho ou não do funcionário com a segurança } \\
\text { do trabalho (.) como que ela é }\end{array}$ \\
\hline $\begin{array}{l}87 \\
88 \\
89 \\
90 \\
91\end{array}$ & EMERSON : & $\begin{array}{l}\text { a (nome da empresa) (.) o médico era a pessoa que } \\
\text { você não podia falar (.) que qualquer conversa } \\
\text { que você tivesse com o médico as pessoas iam } \\
\text { achar que você tava tendo consulta (.) e o medo } \\
\text { era a participação do lucro }\end{array}$ \\
\hline 92 & AMANDA: & como assim $\uparrow$ \\
\hline $\begin{array}{l}93 \\
94 \\
95 \\
96 \\
97 \\
98 \\
99 \\
100 \\
101 \\
102 \\
103 \\
104 \\
105 \\
106 \\
107 \\
108 \\
109\end{array}$ & EMERSON : & $\begin{array}{l}\text { a:a (nome da empresa) tem uma política de } \\
\text { segurança do trabalho que:e quando tem um } \\
\text { acidente você perde a participação de lucro (.) } \\
\text { então se o seu setor sofre um acidente (.) o seu } \\
\text { setor (.) você (.) o teu colega (.) teu chefe (.) } \\
\text { e até acima dele (.) todo mundo perde a } \\
\text { participaça no lucro(.) } \text { o que é uma } \\
\text { participação de lucro na (nome da empresa) }{ }^{2} \text { chega } \\
\text { no final do ano você tem na sua conta é:é (.) } \\
\text { digamos (.) o técnico ganha } 15 \text { mil (.) gerente } \\
\text { ganha } 45 \text { (.) chefe de gerente ganha } 300 \text { mil (.) } \\
\text { e aí (.) aquele (.) pessoal todo (.) perde o:o } \\
\text { o:o a participação no lucro por causa do acidente } \\
\text { (.) então pra evitar isso todo mundo omite (.) a } \\
\text { pior coisa que você tem é conversar com o médico } \\
\text { omédico é a pessoa que você não conversa (.) ele } \\
\text { fica lá na salinha dele jogando paciência (.) ou }\end{array}$ \\
\hline
\end{tabular}




\begin{tabular}{|l|l|l|}
\hline 110 & $\begin{array}{l}\text { lendo livro jornal fazendo qualquer coisa (.) não } \\
111\end{array}$ & pode falar com o médico \\
\hline
\end{tabular}

Emerson destaca o papel da PL na política de segurança do trabalho. Uma das metas que condicionam o recebimento da PL é o acidente zero (tem um acidente você perde a participação de lucro-linhas 94 e 95). E não é apenas o acidentado que perde a participação (se o seu setor sofre um acidente (.) o seu setor (.) você (.) o teu colega (.) teu chefe (.) e até acima dele (.) todo mundo perde a participação no lucrolinha 96 a 99). Logo a pressão pelo acidente zero é de todos, o que leva todos a omitirem a ocorrência de acidentes (pra evitar isso todo mundo omite - linha 106). Há um tipo de contrato informal: o trabalhador não comunica o acidente e a empresa acredita que não há acidente.

Além da denúncia de vista grossa, o Emerson destaca ainda as consequências desse uso da PL como sistema de recompensa:

\section{Excerto $17 \mathrm{~B}$ : ninguém trabalha com segurança}

\begin{tabular}{|c|c|c|}
\hline $\begin{array}{l}112 \\
113 \\
114 \\
\end{array}$ & AMANDA: & $\begin{array}{l}\text { então essa política de:e como você entende essa } \\
\text { política de:e de dar o lucro participação do } \\
\text { lucro quando não há acidente }\end{array}$ \\
\hline $\begin{array}{l}115 \\
116 \\
117 \\
118 \\
119 \\
120 \\
121 \\
122 \\
123 \\
124 \\
125 \\
126 \\
127 \\
128 \\
129 \\
130 \\
131 \\
132 \\
133\end{array}$ & EMERSON & $\begin{array}{l}\text { uma imbecilidade (.) porque o quê que acontece } \\
\text { você:ê passa a não:o comunicar o acidente (.) } \\
\text { porque existe uma uma uma tese uma estatística } \\
\text { que é- chamada pirâmide frank bird né onde } \\
\text { existe:em é:é na base:e existem é:é quatro mil } \\
\text { (.) } 3 \text { mil quase acidentes né e aí existem } 600 \\
\text { acidentes (.) poucos acidentes co:om traumatismo } \\
\text { e uma morte né } \text { então pra cada morte (.) existe }_{\text {(.) na (nome da empresa) existiria } 6 \text { mil quase }} \\
\text { acidentes (.) a ideia é você trabalhar com esses } \\
\text { quase acidentes antes que chegue- vire morte (.) } \\
\text { só que ninguém trabalha com isso (.) todo mundo } \\
\text { se omite (.) onéo }{ }^{\uparrow} \text { na omissão quando morrem } \\
\text { morrem } 15 \text { morre } 20 \text { morre } 30 \text { porque ninguém } \\
\text { trabalha com segurança(.) entendeu as pessoas } \\
\text { sabem que estão acontecendo aqueles problemas (.) } \\
\text { mas evitam de trabalhar com aquilo (.) porque vai } \\
\text { perder dinheiro quando acontece acontece logo } \\
\text { tudo de uma só vez }\end{array}$ \\
\hline
\end{tabular}

Emerson responsabiliza a empresa pela ocorrência de acidentes por meio de duas categorizações. A primeira, a de nomear a prática de condicionar a PL à meta do acidente zero como uma imbecilidade, uma vez que ela incentiva a prática de não comunicar acidentes (uma imbecilidade (.) porque o quê que acontece 
você:ê passa a não: o comunicar o acidente - linha 115 e 116). E sustenta essa posição incluindo uma estatística que aponta a relevância do que nomeia como "quase acidente" para evitar acidentes mais graves (a ideia é você trabalhar com esses quase acidentes antes que chegue- vire morte (.) só que ninguém trabalha com isso - linha 124 a 126).

Além da perda da PL, a política de acidente zero está relacionada também à perda do emprego:

\section{Excerto 18: às vezes o próprio colaborador omite}

\begin{tabular}{|c|c|c|}
\hline $\begin{array}{l}176 \\
177 \\
178 \\
179 \\
180 \\
181 \\
182 \\
183 \\
184 \\
185 \\
186 \\
187 \\
188 \\
189 \\
190 \\
191 \\
192 \\
193 \\
194\end{array}$ & OBSON : & $\begin{array}{l}\text { o quê que acontece (.) } 0 \text { supervisor (.) } \\
\text { encarregado e o gerente da área eles não querem } \\
\text { gerar informar um acidente (.) então ele vai } \\
\text { pormenorizar (.) você torceu o pé (.) tá doendo } \\
\text { (.) tá doendo um pouco aí vai bota um gelo ali na } \\
\text { hora (.) daqui a pouco tá bem (.) levantou (.) vai } \\
\text { trabalhar (.) } \text { então ele não notifica (.) porque a } \\
\text { Amanda continua a trabalhar mas daqui a três dias } \\
\text { a Amanda tá com o pé desse tamanho não tem como } \\
\text { vir trabalhar aí vai pro hospital ppô você tinha } \\
\text { uma fratura pequenininha no tornozelo (.) aí a } \\
\text { Amanda botou um gesso e agora eu tenho até } 24 \\
\text { horas pra emitir uma notificação de acidente de } \\
\text { trabalho (.) você só me informou no quarto dia (.) } \\
\text { por que o encarregado (.) supervisor e às vezes o } \\
\text { próprio colaborador omite (.) porque ele quer } \\
\text { segurar o trabalho dele (.) tá com medo de falar } \\
\text { (.) não fala e fica assim (.) em contrapartida a } \\
\text { segurança do trabalho fica perdida }\end{array}$ \\
\hline
\end{tabular}

Por meio de uma narrativa fictícia, Robson ilustra o que acontece na realidade. Por um lado, as lideranças não querem envolvimento na ocorrência de acidentes no seu setor, daí a omissão (eles não querem gerar informar um acidente (.) então ele vai pormenorizar-linha 177 a 179). Do mesmo modo, o próprio colaborador sabe que, ao se acidentar, ele corre o risco de perder o emprego, daí a prática da não comunicação de acidente (o ipróprio colaborador omite (.) porque ele quer segurar o trabalho dele (.) tá com medo de falar (.) não fala - linha 190 a 193). Em sua conclusão, observa-se que a empresa sabe que em função dessas práticas a segurança fica perdida(fica assim (.) em contrapartida a segurança do trabalho fica perdida - linhas 193 e 194).

Além das lideranças, dos colaboradores, a própria empresa é acusada de não comunicar acidentes: 


\section{Excerto 19: não tem comunicação de acidentes}

\begin{tabular}{|c|c|c|}
\hline $\begin{array}{l}35 \\
36 \\
37 \\
38 \\
39 \\
40 \\
41 \\
42 \\
43\end{array}$ & RITA: & $\begin{array}{l}\text {. hhh tem empresas que nem comunicam (.) tem empresas } \\
\text { que nem comunicam na:a > nome da empresa)< que eu } \\
\text { trabalhei há pouco tempo um funcionário perdeu o } \\
\text { braço e assim (.) o<fica tudo:o>o >por isso mesmo< } \\
\text { então depende muito da cultura da empresa } \text { paqui onão } \\
\text { é comunicado }{ }^{\circ} \text { (.) então a gente tem que:e (.) eu vou } \\
\text { falar mais assim (.) é: (.) >é falta de comunicação< } \\
\text { va- vamos pensar na empresa geral (.) <não tem } \\
\text { comunicacão de acidentes> }\end{array}$ \\
\hline
\end{tabular}

O tema de comunicação de acidentes é tão delicado que observamos que, na fala da Rita, a descida de volume da voz, o quase sussurrar, o medo de alguém ouvir ela dizer que naquela empresa não há comunicação de acidente ( $\uparrow$ aqui ${ }^{\circ}$ não é comunicado - linhas 39 e 40). Além da micro pausas, que apontam para algum nível de planejamento do que dizer, Rita reorienta sua avaliação, ao abandonar a especificação((.) então a gente tem que:e (.) eu vou falar mais assim (.) - linhas 40 e 41) generalizando a prática de não comunicação de acidente (vamos pensar na empresa geral (.) <não tem comunicação de acidentes $>$ - linhas 42 e 43 ).

Como mostram os excertos, há uma crença de que a prática da omissão é uma praxe nas empresas. E se considerarmos que a descrição dos fatos reais, no Método de Árvore de Causas, pode contribuir para a identificação dos fatores potenciais de acidente (BINDER \& ALMEIDA, 1997), pode-se concluir que essa prática impede a possibilidade de mensurá-los e consequentemente de prevenir outros acidentes.

\section{3 .2}

\section{A prática da maquiagem de informações}

Outra explicação que aponta a responsabilidade da empresa diz respeito às práticas de maquiagem utilizadas para comunicar informações desfavoráveis.

\section{Excerto 20: não é uma estatística real é meio que nublado isso aí}

\begin{tabular}{|l|l|l|l|}
\hline 201 & ROBSON: & numa empresa chamada (nome da empresa) >que \\
202 & & prestava serviço pra (nome da empresa) \\
203 & & (nome da empresa) diz o seguinte (.) olha ele \\
204 & & torceu o pé tem que ficar 30 dias (.) a (nome da \\
205 & & empresa) toncava táxi pra levar ele pra empresa \\
\hline
\end{tabular}




\begin{tabular}{|l|l|l|}
\hline 206 & pra ele ficar sentado o dia inteiro sem fazer \\
207 & nada (.) pra dizer que ele o cara não teve \\
208 & afastamento (.) porque sai mais $\uparrow$ caro pra ela com \\
210 & afastamento do que- (.) ela botar um táxi pra \\
211 & buscar e levar ele então assim $\uparrow$ não é uma \\
212 & estatistica real (.) é meio que:e é-é:é nublado \\
& isso aí
\end{tabular}

Robson deslegitima as estatísticas de acidentes apresentadas pelas empresas por uma prática de burlar a contabilização de dados reais. A entrevista oferece uma evidência dessa prática para maquiar um caso de afastamento (a (nome da empresa) †bancava táxi pra levar ele pra empresa pra ele ficar sentado o dia inteiro sem fazer nada (.) pra dizer que ele o cara não teve afastamento - linhas 2014 a 208). O exemplo também mostra que não são só as lideranças e os empregados que evitam assumir a ocorrência de acidentes. A empresa também adota essa prática.

Outra prática de prática de maquiagem é invocada:

\section{Excerto 21: as empresas costumam tendenciar os relatórios finais}

\begin{tabular}{|c|c|c|}
\hline $\begin{array}{l}216 \\
217\end{array}$ & AMANDA: & $\begin{array}{l}\text { sim entendi como você acha que as empresas } \\
\text { costumam explicar os acidentes }\end{array}$ \\
\hline 218 & ROBSON : & explicar \\
\hline 219 & AMANDA: & isso \\
\hline $\begin{array}{l}220 \\
221 \\
222 \\
223 \\
224 \\
225 \\
226 \\
227\end{array}$ & $\mathrm{ROBSON}$ & $\begin{array}{l}\text { quando morre é mais fácil porque a gente bota } \\
\text { culpando o morto o morto não fala }(3,2) \text { então não } \\
\text { normalmente as empresas costumam tendenciar os } \\
\text { relatórios finais de seus acidentes pro não } \\
\text { aplicabilidade do procedimento (.) essa é uma } \\
\text { forma que ela tem (.) assim o cara não contribui } \\
\text { (.) não cumpriu a norma (.) então normalmente } \\
\text { acontece isso }\end{array}$ \\
\hline
\end{tabular}

A maquiagem aqui é nomeada como um tendencionamento de informações nos relatórios finais. Essa maquiagem é outro meio utilizado pelas empresas para não assumir a sua parcela de responsabilidade nos acidentes. Para tanto, ela se vale de account do tipo excuse, isto é, aqueles que apontam fatores externos para explicar um acidente. A prática mais comum, como vimos, é colocar no relatório que o acidente se deu a um ato inseguro do acidentado (as empresas costumam tendenciar os relatórios finais de seus acidentes pro não aplicabilidade do procedimento - linha 222 a 224).

Em um outro excerto de Felipe, vemos a prática das excuses utilizada para responsabilizar um elemento não humano: 


\section{Excerto 22: bota a culpa em algum equipamento que falhou}

\begin{tabular}{|l|l|l|l|}
\hline 132 & FELIPE: & a gente sempre tenta arrumar na hora de \\
133 & & investigação de acidentes (.) ou bota a culpa em \\
134 & & algum equipamento que falhou ou no morto que fez \\
135 & & aquilo (.) mas dificilmente o morto tem culpa (.) \\
136 & & mas dificilmente ele fez sozinho
\end{tabular}

Neste caso, o único agente a ser responsabilizado pode vir a ser o fabricante ou, então, alguma falha material impossível de ter sido evitada.

Em um outro exceto, podemos identificar a crença de que a empresa "nunca" fala a verdade.

\section{Excerto 23: nunca tem um discurso verdadeiro}

\begin{tabular}{|c|c|c|c|}
\hline & $\begin{array}{l}142 \\
143\end{array}$ & AMANDA: & $\begin{array}{l}\text { como você acha que as empresas costumam explicar } \\
\text { os acidentes que ocorrem }\end{array}$ \\
\hline & $\begin{array}{l}144 \\
145 \\
146 \\
147 \\
148 \\
149 \\
150 \\
151 \\
152 \\
153 \\
154 \\
155 \\
156 \\
157 \\
158 \\
159 \\
160 \\
161 \\
162\end{array}$ & FELIPE: & 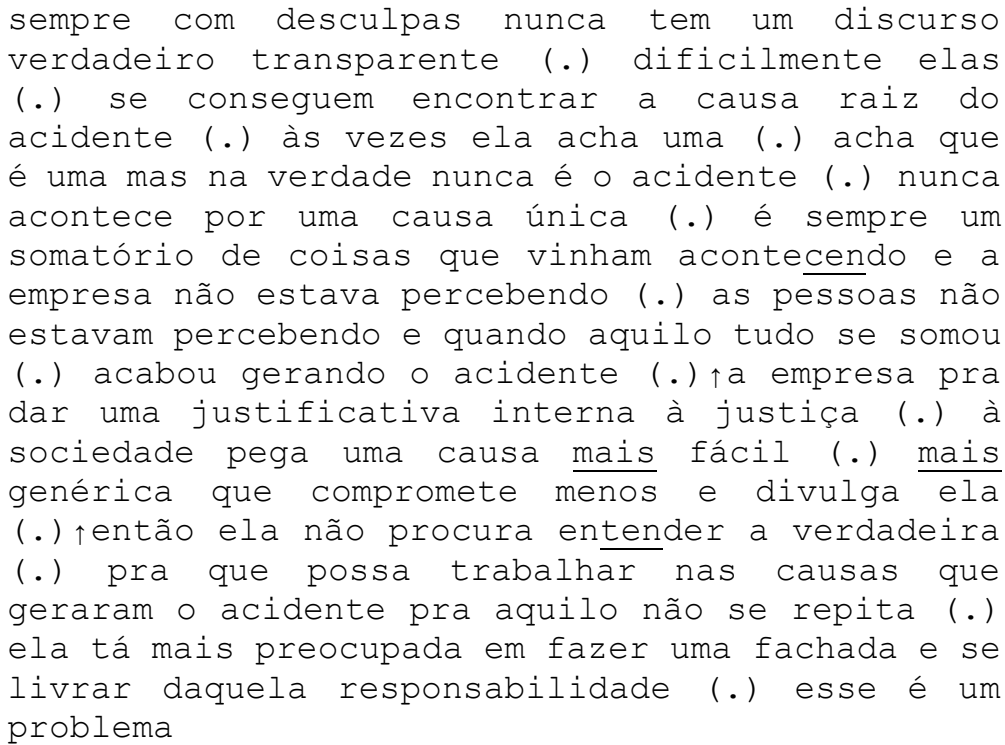 \\
\hline
\end{tabular}

Um ponto a ser destacado aqui é o uso do termo "desculpas". Diferentemente do que a literatura aponta, desculpas aqui não são realizadas para reconhecer ao erro, assumir a responsabilidade, mostrar arrependimento e assumir que isso não se repetirá. Desculpas aqui é usada no sentido de senso comum, no sentido justificativas sustentadas por fatores externos, de modo a se eximir da responsabilidade pelo ocorrido.

Esse tipo de crença alimenta uma outra: a de que empresa não é confiável (nunca tem um discurso verdadeiro transparente-linha 144 e 145), o que coloca sob suspeita todos os seus discursos e práticas. No caso de investigação de acidentes, haverá, assim, sempre desconfiança em relação ao que foi apurado, pois 
há uma crença na motivação para o que foi apresentado como causa do acidente: o trabalho de gerenciamento da sua imagem (tá mais preocupada em fazer uma fachada e se livrar daquela responsabilidade (.) esse é um problema - linha 160 a 162).

Se considerarmos, como afirma Perrow (1999), que investigações simplistas de acidentes é um dos fatores principais para ocorrência de outros acidentes, concluímos que a prática da maquiagem é uma inimiga da segurança, pois é uma ação intencional, com conhecimento de consequências, o que só agrava a responsabilidade da empresa.

Este capítulo mostrou, portanto, o modo como os entrevistados tendem mais a buscar culpados do que considerar a responsabilidade de todos para uma política de segurança no trabalho. Mostrou também como os entrevistados atribuem responsabilidade às empresas pela ocorrência de acidentes de trabalho, seja pela desvalorização do profissional de segurança e saúde do trabalho, criando obstáculos por meio de sua cultural empresarial ou por políticas que permitem algumas lacunas na segurança. 


\section{7}

\section{Considerações Finais}

O presente estudo investigou, à luz de uma abordagem etnometodológica, o modo como as lideranças explicam os acidentes de trabalho, que concepções de senso comum sustentam as explicações que apontam a responsabilidade do trabalhador e de outros agentes para os acidentes. Nosso objetivo foi o de contribuir para o entendimento dos acidentes de trabalho, vendo o problema a partir de uma perspectiva que privilegia o uso da linguagem.

Nessa linha, procuramos levantar 3 perguntas de pesquisa, cujas respostas retomamos aqui.

Em relação à primeira pergunta: Quais as teorias internas que as lideranças envolvidas em gestão da segurança do trabalho têm para explicar os acidentes?

Como mostrou a análise, as teorias internas da liderança refletem crenças associadas a teorias tradicionais de causas de acidente em que o ato inseguro é o causador do acidente.

Em relação à segunda pergunta: Que crenças de senso comum sustentam essas teorias?

Uma das crenças de senso comum que se mostrou relevante nas explicações para o processo de culpabilização do empregado diz respeito a uma visão de cultura como uma "camisa-de-força". Não se reconhece a possibilidade de o trabalhador mudar o código construído por suas experiências, seus saberes, suas práticas. Mais ainda, estigmatiza-se o trabalhador como alguém que não tem agência, que é pouco responsável, pouco educado, e de conhecimentos limitados. A partir dessa visão, não se acredita que o trabalhador possa fazer escolhas de ação diferentes das aprendidas, modificar os valores construídos ao longo da sua história de vida. Se por um lado, isso serve à culpabilização do empregado, por outro serve à desresponsabilizacão da liderança (e até da empresa), uma vez que a cultura não é vista como uma construção coletiva e dinâmica. A cultura, os valores são refletidos e constituídos nas práticas de todos em suas interações.

Em relação à terceira pergunta: Como a questão da responsabilidade emerge nas explicações oferecidas pelas lideranças para a ocorrência de acidentes? 
Os resultados mostraram que escolhas lexicais e estratégias discursivas utilizadas pelos participantes foram utilizadas para invocar os pilares da noção de responsabilidade. Em relação ao trabalhador, esses recursos de linguagem evidenciaram que o trabalhador sabe do risco, conhece os procedimentos de segurança e, mesmo assim, corre o risco, como uma escolha intencional. Essas escolhas de linguagem agravam a responsabilidade do trabalhador, o que pode ser utilizado em eventuais processos de responsabilidade civil com favorecimento dos interesses do empregador. A responsabilidade civil do empregador torna-se excludente quando é atribuída a culpa exclusivamente à vítima, em função de sua conduta, seja por descaso intencional, quando o funcionário provoca o acidente, seja por culpa consciente, quando o mesmo negligencia orientações dadas pelo empregador para a realização da atividade (GAMBA, 2010).

Em relação à quarta pergunta: Quem é responsabilizado e desresponsabilizado?

Como mostra a análise, o trabalhador é quem é mais fortemente responsabilizado, o que evidencia a persistência da noção de ato inseguro. No entanto, a empresa também é responsabilizada pelos acidentes de trabalho. Embora essa responsabilidade não tenha sido apontada quando os entrevistados culparam o trabalhador, observa-se que, como apontam Oliveira e Silva (2009), a organização se constitui nas interações cotidianas, nas práticas comunicativas, nas relações sociais, na estrutura organizacional, etc. Logo nenhum comportamento pode ser visto isoladamente, todos estão co-construindo uma realidade. No caso da segurança, fica claro para os entrevistados que, se o exemplo não vem de cima, não se constrói uma cultura de segurança. Sem o comprometimento da Direção com a construção de uma cultura de segurança, não se valoriza segurança.

Mais uma vez, as explicações para a responsabilização de um agente são sustentadas pela crença na força da cultura, no caso, da cultura organizacional. Como observado no processo de culpabilização do trabalhador, a cultura serve também aqui para a desresponsabilizar os engenheiros e profissionais de segurança. Tudo o que a empresa faz e deixa de fazer mostra o quanto a segurança é também para ela um valor. Se suas práticas são orientadas pelo lucro, pela produtividade e por práticas para camuflar estatísticas ou criar ficções de realidade, os líderes não veem como não replicar essas práticas, já que não teriam poder para mudá-las. 
Se a distância social entre liderança e trabalhador explicava, de um certo modo, a dificuldade de colocar em diálogo "dois mundos diferentes", aqui é a cultura hierárquica, pouco participativa que justifica o silêncio/a omissão da liderança que se vê incapacitada de mudar uma realidade, e a crença na impossibilidade de atuar para uma mudança.

Acreditamos que os resultados encontrados apontam para a necessidade de uma revisão de uma visão mecanicista de organização e de comunicação, que apaga o lugar de sujeito do trabalhador e desconhece o papel da agência de todos os membros da organização na construção de uma cultura de segurança. Como mostram as análises, os entrevistados alimentam crenças que os impedem de ver com clareza e imparcialidade o que contribui para a ocorrência de acidentes. Se a empresa e a liderança estão aprisionadas por crenças equivocadas, mudá-las é o primeiro passo para construir uma cultura de segurança e um programa de prevenção de acidentes eficaz.

O estudo dos etnométodos para explicar acidentes pode ser ampliado e discutido em treinamentos e cursos de formação de líderes. Sem um processo continuo de informação e conscientização de todos, direção, liderança e trabalhadores, não se constrói um caminho para uma mudança cultural. É preciso deixar de "caçar culpados" e assumir que todos são, de algum modo, responsáveis pelo sucesso ou fracasso do processo de desenvolvimento de uma cultura de segurança. Sem o estigma da culpa e a partir da crença na distribuição de responsabilidade, pode-se elaborar programas de segurança mais eficazes. 


\section{Referências bibliográficas}

AHEARN, L. M. Agency and Language. In: Jaspers, J.; Östman, J.; Verschueren, J. (Eds.). Handbook of Pragmatics Highlights, n. 7: Society and Language Use. Amsterdã: John Benjamins, 2010. p. 28 - 48.

ALMEIDA, I. M. The path of accident analysis: the traditional paradigm and extending the origins of the expansion of analysis. Interface Comunicação, Saúde, Educação, v.10, n.19, p.185-202, jan/jun 2006

ALMEIDA, I. M.; FILHO, J. M. J. Acidentes e sua prevenção. Revista Brasileira de Saúde Ocupacional, São Paulo, v. 32, n. 115, p. 7-18, 2007.

ALMEIDA, N.D.V.; Lima, A. K. B.; Albuquerque, C. M.; Antunes, L. As relações de gênero e as percepções dos/das motoristas no âmbito do sistema de trânsito. Psicologia: ciência e profissão. vol.25 no.2 Brasília Junho 2005

ALMEIDA, N.D.V. Contemporaneidade X Trânsito: Reflexão Psicossocial do Trabalho dos Motoristas de Coletivo Urbano. Psicologia Ciência e Profissão, 22(3), 2002b, pp. 62-69.

ALVES, J. L. L.; JUNIOR, L. C. DE M. Mudança cultural orientada por comportamento: elementos para uma cultura de saúde, segurança, confiabilidade e produtividade, atuando com as pessoas. Rio de Janeiro: Qualitymark Editora, 2013.

ANTAKI, C. Analysing Everyday Explanation: A Casebook of Methods. Thousand Oaks, CA: Sage, 1988.

ARRIBAS-AYLLON, M.; SARANGI, S.; CLARKE, A. Genetic Testing: Accounts of Autonomy, Responsibility and Blame. Londres: Routledge, 2011.

BALLARDIN, L. Análise de trabalho de operadores de uma distribuidora de derivados de petróleo. Porto Alegre: Dissertação de mestrado. UFRGS, 2007.

BERGAMINI, C. W. Uma revisão da evolução histórica dos estudos e pesquisas sobre liderança enfatiza a importância de líderes organizacionais 
eficazes. Revista de Administração de Empresas/EAESP/FGV, São Paulo, 1994, v. 34, n. 3, p.102-114.

BIAR, L. Demarcando território? Situando a Linguística Aplicada indisciplinar. Linguagem em (re)vista, ano 6, n. 10, 2009.

BILLIG, M. Arguing and Thinking: A Rhetorical Approach to Social Psychology. Cambridge: Cambridge University Press, 1996.

BINDER, M. C. P.; ALMEIDA, I. M. de. Estudo de caso de dois acidentes do trabalho investigados com o método de árvore de causas. Caderno Saúde Pública, Rio de Janeiro, 13(4):749-760, out-dez, 1997.

BRANDÃO, Cláudio. Acidente do trabalho e responsabilidade civil do empregador. 3.ed. São Paulo: LTR, 2009.

BRASIL (2004). Normas Regulamentadoras de Segurança e Saúde no Trabalho. Ministério do Trabalho Emprego. NR 1 a 36 - 2004

BUTTNY, R. Social accountability in communication. London: Sage, 1993.

CÂMARA, G R. ASSUNÇÃO, A. A.; LIMA, F. P. A. Os limites da abordagem clássica dos acidentes de trabalho: o caso do setor extrativista vegetal em Minas Gerais. Revista Brasileira de Saúde Ocupacional, São Paulo, 32 (115): 41-51, 2007.

CAMARGO, G. A. Sobre o conceito de verdade em Nietzsche. Revista Trágica: estudos sobre Nietzsche $-2^{\circ}$ semestre de 2008 - Vol. 1 - nํㄴ pp.93-112

COLE, K. S.; STEVENS-ADAMS, S. M.; WENNER, C. A. A literature review of safety culture. Report, Albuquerque, New Mexico, 2013.

COSTA, D.; LACAZ, F. A. DE C.; FILHO, J. M. J.; VILELA, R. A. G. Saúde do Trabalhador no SUS: desafios para uma política pública. Revista Brasileira de Saúde Ocupacional, São Paulo, v. 38, n. 127, p. 11-21, 2013.

COULON, A. La etnomedotología (3a ed.). Madrid: Cátedra, 2005.

DENZIN, N.K.; LINCOLN, Y. S. (Orgs.). O Planejamento da Pesquisa Qualitativa: teorias e abordagens. 2ª . Ed. Porto Alegre, Artmed Bookman, 2006

DURANTI, A. Agency in language. In: DURANTI, A. (Ed.) A Companion to Linguistic Anthropology. New York: Blackwell, 2004. p. 451 - 73. 
DWYER, T. A produção social do erro: o caso dos acidentes ampliados. In: FREITAS et ali. Acidentes Industriais ampliados. Rio de Janeiro: Fiocruz, 2000.

Life and Death at Work: Industrial Accidents as a Case of Socially Produced Error. Plenum Press, New York, 1991.

GAGLIANO, P. S.; FILHO, R. P. Novo Curso de Direito Civil: responsabilidade civil. 9.ed. São Paulo: Saraiva, 2011.

GAMBA, Juliane Caravieri Martins. Responsabilidade civil objetiva do empregador pelos danos à saúde do trabalhador: uma visão constitucional do meio ambiente do trabalho. Revista de Direito Constitucional e Internacional, São Paulo: RT, n.71, 2010.

GARCEZ, P. M.; BULLA, G. da S.; LODER, L. L. Práticas de pesquisa microetnográfica: geração, segmentação e transcrição de dados audiovisuais como procedimentos analíticos plenos. D.E.L.T.A., vol. 30, n. 2, 2014.

GARFINKEL, H. (2006). Studios en etnometodología. Barcelona: Anthropos

Studies in ethnomethodology, Englewood Cliffs, New Jersey: Prentice-Hall, 1967.

GHERARDI, S. Organizational knowledge: the texture of workplace learning. Oxford: Blackwell Publishing, 2006.

GIDDENS A. As consequências da modernidade. Tradução de Raul Fiker. São Paulo: Editora Unesp; 1990.

A terceira via: reflexões sobre o impasse político atual e o futuro da social-democracia. 5. ed. Tradução Maria Luiza X. de A. Borges. Rio de Janeiro: Record, 2005.

. The Constitution of Society. Cambridge: Polity Press, 1984.

GIELEN, A. C. Health Education and injury control: integrating approaches. Health Educ. Q., v.19, n.2, p.203-18, 1992.

GOGUELIN, P. La prévention des risques professionnels. Paris: Presses Universitaires de France, 1996.

GOFFMAN, E. A Representação do Eu na Vida Cotidiana. 15. ed. Petrópolis: Ed. Vozes, [1959] 2008.

Interaction ritual: essays on face-to-face interaction. Oxford, England: Aldine, 1967. 
. The Nature of Deference and Demeanor. American Anthropologist, 58: 473-502, 1956.

Footing. In: RIBEIRO, B. T. e GARCEZ, P. M. (orgs.) Sociolinguística Interacional. São Paulo: Editora Loyola, [1979] 2002. $2^{\mathrm{a}}$ Edição revista e ampliada.

GONÇALVES, Carlos Roberto. Direito civil brasileiro: responsabilidade civil. 6.ed. São Paulo: Saraiva, 2011.

GUÉRIN, F.; LAVILLE, A.; DANIELLOU, F.; DURAFFOURG, J.; KERGUELEN, A. Comprender o trabalho para transformá-lo: a prática da ergonomia. São Paulo: Edgard Blücher, Fundação Vanzolini, 2004.

HADDON JR., W.; BAKER, S. P. Injury control. In: CLARK, D. W.; MACMAHON, B. Preventive and community medicine. Boston: Little, Brown and Company, 1981. p.109-40.

HADDON JR., W. On the scape of tigers: an ecologic note. J. Trauma, v.13, p.321$31,1973$.

HAGUETTE, T.M.F. Metodologias qualitativas na sociologia. 3. ed. Petrópolis: Vozes; 1992.

HEALTH AND SAFETY COMISSION. Proposals for a new duty to investigate accidents, dangerous occurrences and diseases. London: Health and Safety Executive, 2001. Disponível em: <www.hse.gov.uk>. Acesso em: 09 de janeiro de 2018.

HEALTH AND SAFETY EXECUTIVE. Investigating accidents and incidents: a workbook for employers, unions, safety representatives and safety professionals. London: Her Majesty's Stationery Office, 2004.

HEALTH AND SAFETY EXECUTIVE. Root causes analysis. Norwich: Her Majesty's Stationery Office, 2001.

HEINRICH, H. W. Industrial accident prevention. New York: McGraw-Hill Book Company, 1959.

HERITAGE, J. C. Ethnomethodology. In A. Giddens \& J. Turner (Eds.), Social theory today (pp. 224-272). Cambridge: Polity Press, 1987.

HERSEY, P.; BLANCHARD, K. H. Psicologia para administradores: a teoria e as técnicas da liderança situacional. São Paulo: EPU, 1986.

KATSAKIORI, P., SAKELLAROPOULOS, G., MANATAKIS, E. (2009). Towards an evaluation of accident investigation methods in terms of their alignment with accident causation models. Safety Science.47: 1007-1015. 
LEITE, A. DA S. Percepções de Segurança do Trabalho em Diferentes Níveis Hierárquicos - Estudo de Caso. Dissertação de Mestrado, Departamento de Engenharia de Produção, UFF, Niterói, 2015.

MACHADO,J.M.H.; PORTO,M.F.S.; FREITAS, C. M. Perspectivas para uma análise interdisciplinar e participativa de acidentes no contexto da indústria de processo. In: Acidentes Industriais Ampliados. Rio de Janeiro: Fiocruz Editora, 2000. p. 49-81.

MANGUALDE, Juliana de Castro. A responsabilidade civil do empregador pelo acidente do trabalho. 2008. 96 f. Dissertação de Mestrado, Faculdade de Direito Milton Campos, Nova Lima, 2008.

MARTINS, Sérgio Pinto. Direito da Seguridade Social. 31.ed. São Paulo: Atlas, 2011.

MEAD, G. H. (1934). Mind, Self, and Society: From the standpoint of a Social Behaviourist. Edited by C. W. Morris. Chicago: University of Chicago Press.

MINAYO, M. C. de S. Amostragem e Saturação em Pesquisa Qualitativa: consensos e controvérsias. Revista Pesquisa Qualitativa. São Paulo (SP), v. 5, n. 7, p. 01-12, abril. 2017

MOITA, L.P.L. Contemporaneidade e construção de conhecimento na área de estudos linguísticos. SCRIPTA, Belo Horizonte, v. 7, n. 14, p. 159-171, 2004.

Monteiro, A. L. de O.; Medani, L. V.; Estudo de segurança de proteção industrial na produção de amônia por gás de síntese. TCC Departamento de Engenharia Química e de Petróleo - UFF. Niterói, RJ: [s.n.], 2015. 198f.

NIEBUHR, H. R. The responsible self: An Essay in Christian Moral Philosophy. Louisville, KY: Westminster John Knox Press, (1999 [1963]).

OLIVEIRA, F. A Construção Social dos Discursos sobre o Acidente de Trabalho. Dissertação de Mestrado, Instituto de Psicologia, USP, 1997.

A persistência da noção de ato inseguro e a construção da culpa: os discursos sobre os acidentes de trabalho em uma indústria metalúrgica. Revista Brasileira de Saúde Ocupacional, São Paulo, 32 (115): 19-27, 2007.

OLIVEIRA, M. do C. L. Conflicting Moralities in an Interaction between a Police Officer and a Driver. 18th World Congress of Applied Linguistics (AILA). Morality in Professional Encounters Symposium. Julho-Agosto 2017,RJ, Brasil. 
OLIVEIRA, S. A. de, Montenegro, L. M., Machado-da-Silva, C. L., \& Rese, N. (2010, maio). Etnometodologia: desvelando a alquimia da vivência cotidiana. Anais do Encontro da Divisão de Estudos Organizacionais da ANPAD, Florianópolis, SC, Brasil, 6

ÖSTMAN, J-O. e SOLIN, A. Introduction: Discourse and responsibility. Journal of Applied Linguistics and Professional Practice. Ed.: Equinox. 2012.

PERROW, C. Normal accidents. Nova Jersesy: Princeton University Press. 439 p., 1999.

PINA, J. A.; STOTZ, E. N. Participação nos lucros ou resultados e banco de horas: intensidade do trabalho e desgaste operário. Revista brasileira Saúde ocupacional, São Paulo, 36 (123): 162-176, 2011

PONTES, L. C. Cultura de segurança e suas implicações na prevenção de acidentes do trabalho. Dissertação (Mestrado), Faculdade Novos Horizontes, Belo Horizonte, 2008.

RASMUSSEN, J. Risk management in a dymanic society: a modeling problem. Safey Science, v.27, n.2 e 3, p.183-213:1997.

RAWLS, A. W. Harold Garfinkel, ethnomethodology and workplace studies. Organization Studies. 29(5), 701-732. 2008.

REASON, J. Human Error. England: Cambridge University Press. 1990.

Human error: models and management. BMJ, v. 320, 2000.

ROBBINS, S. P.; JUDGE, T. A. Fundamentos do comportamento organizacional. 12. Ed. - São Paulo: Pearson Education do Brasil, 2014.

ROBINSON, J. D.; BODEN, G. B. Preference organization of sequenceinitiating actions: The case of explicit account solicitations. In: Discourse Studies. v. 12, n. 4, p. 501-533, 2010.

ROMERO, J. J. C. Etnometodologia: una explicación de la construcción social de la realidad. Revista Española de Investigaciones Sociológicas, 56, 83-114, 1991.

SACKS, H., SCHEGLOFF, E. A. e JEFFERSON, G. Sistemática elementar para a organização da tomada de turnos para a conversa. Veredas, vol. 7, n. 1-2, 2003.

SARANGI, S. Owning responsible actions/selves: Role-relational trajectories in counselling for childhood genetic testing. Journal of applied linguistics and professional practice. 2012, Vol. 9 Issue 3, p295-318. 
Role hybridity in professional practice. In SARANGI, S., POLESE, V. and CALIENDO, G. (Eds.) Genre(s) on the Move: Hybridisation and Discourse Change in Specialised Communication. Napoli: Edizioni Scientifiche Italiane (ESI), 2011.

SCOTT, Marvin B. [e] LYMAN, Stanford. Accounts. Dilemas: Revista de Estudos de Conflito e Controle Social. Vol. 1, no 2, pp. 139-172. 2008[1968]

VALE. FISPQ. Amônia. 2012. Disponível em: http://www.valefertilizantes.com/mda/modulos/conteudo/relinvestidores/fispq Ldocs/am\%c3\%83\%c2\%b4nia\%20anidra\%20nh3.pdf >. Acesso em: 09/01/2018.

VERGARA, Sylvia Constant. Gestão de Pessoas. São Paulo: Atlas, 2009.

VIEIRA, F. G. D.; Crubellate, J. M.; Silva, I. G.; Silva, W. R.; Silêncio e Omissão: aspectos da cultura brasileira nas organizações. Editora: Fundação Getúlio Vargas - Escola de Administração de Empresas de São Paulo. RAE-eletrônica, Volume 1, Número 1, jan-jun/2002.

WERNECK, A. Moralidade de bolso: A 'manualização' do ato de dar uma desculpa como índice da negociação da noção de 'bem' nas relações sociais. DILEMAS, P. 107-141, 2008 


\section{Anexo}

\section{Anexo I - Convenções de transcrição.}

\begin{tabular}{|l|l|}
\hline$(0.5)$ & Pausa em décimos de segundo \\
\hline$()$. & Micropausa de menos de dois décimos de segundo \\
\hline$[$ colchetes] & Fala sobreposta \\
\hline$=$ & $\begin{array}{l}\text { Contiguidade entre a fala de um mesmo falante ou de } \\
\text { dois falantes distintos }\end{array}$ \\
\hline$\cdot$ & entonação descendente ou final de elocução \\
\hline$?$ & entonação ascendente \\
\hline, & entonação de continuidade \\
\hline$\uparrow$ & subida de entonação \\
\hline$\downarrow$ & descida de entonação \\
\hline- & Auto-interrupção \\
\hline sublinhado & Ênfase \\
\hline MAlÚSCULA & Fala em voz alta ou muita ênfase \\
\hline opalavrao & Palavra em voz baixa \\
\hline$>$ palavra< & Fala mais rápida \\
\hline$<$ palavra> & fala mais lenta \\
\hline$:$ ou :: & alongamentos \\
\hline$($ ) $)$ & fala não compreendida \\
\hline$(())$ & $\begin{array}{l}\text { comentário do analista, descrição de atividade não } \\
\text { verbal }\end{array}$ \\
\hline "palavra" & fala relatada, reconstrução de um dialogo \\
\hline hh & aspiração ou riso \\
\hline
\end{tabular}

Convenções baseadas em Sacks, Schegloff e Jefferson ([1974] 2003) com incorporação de símbolos sugeridos por Tannen (2007). 